


\section{Digitized by the Internet Archive in 2010 with funding from Lyrasis Members and Sloan Foundation}




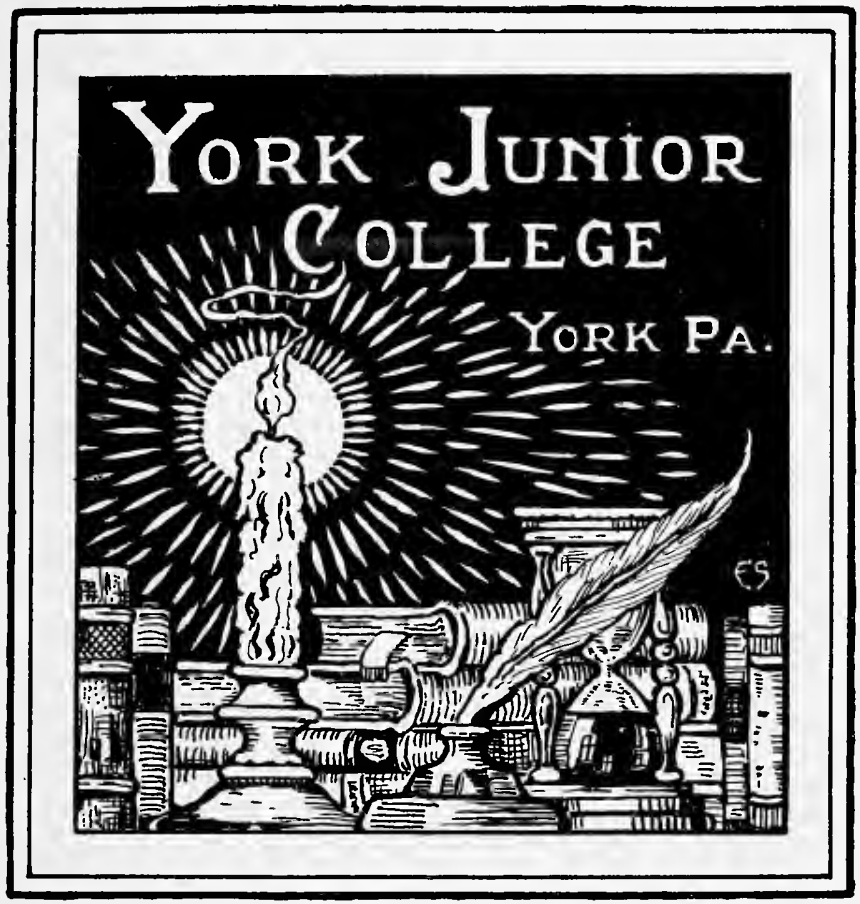

This book mas presented by ...

Francis Farquhar 

To his esteemed fiend, the Hon. A. B. Farquar, from the author. 1916. 


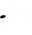




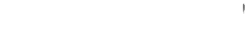




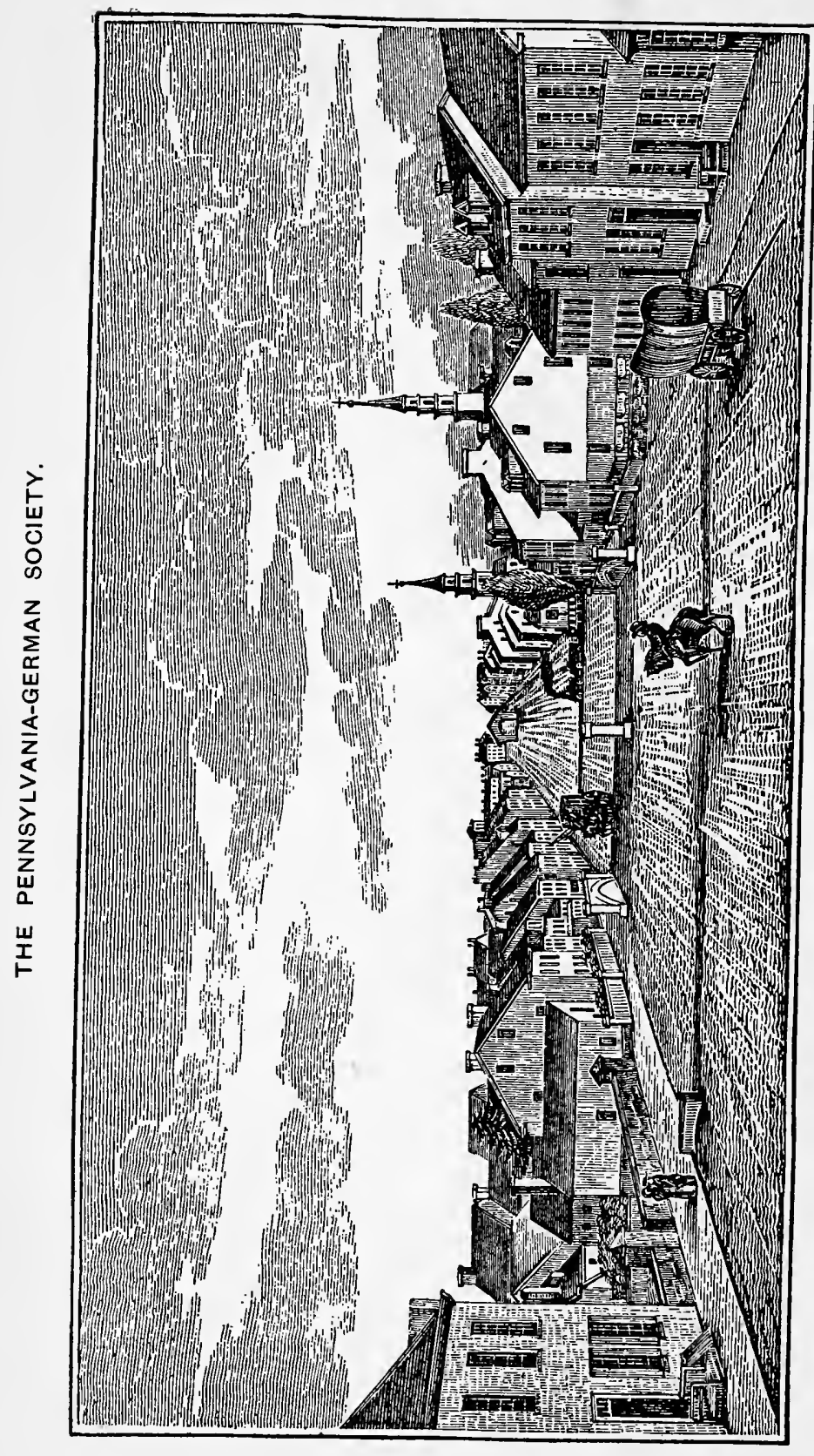

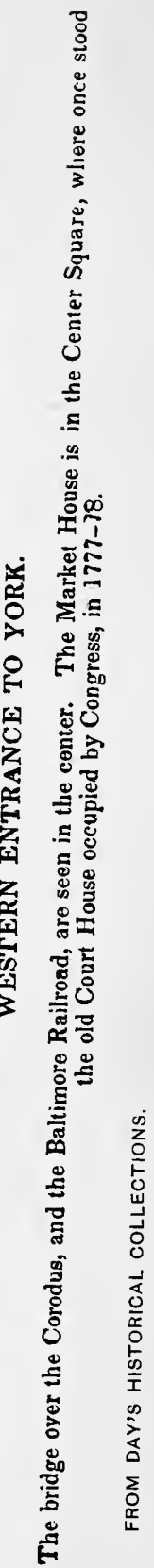




\title{
The JBeginnings of the
}

\section{German Element ín Work County IPennsplvanía}

\author{
BY \\ ABDEL ROSS WENTZ, B.D., PH.D. \\ Professor of History in Pennsylvania College, Gettysburg, and Curator of the \\ Historical Society of the Evangelical Lutheran Church in the \\ United States of America
}

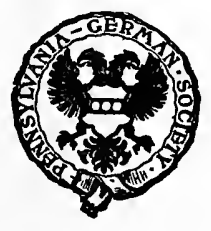

23648

LANCASTER, PA. I9I6 
REPRINTED FROM VOLUME XXIV OF THE PROCEEDINGS OF THE PENNSYLVANIA-GERMAN SOCIETY

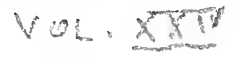

Copyrighted, I9I6

By the

PENNSYLVANIA-GERMAN SOCIETY 
$F \quad 1$

157

y6

W 48

GTASS
CASE

ThIS VOLUME IS GRATEFULLY INSCRIBED TO THE MEMORY OF

\section{PHILIP H. GLATFELTER}





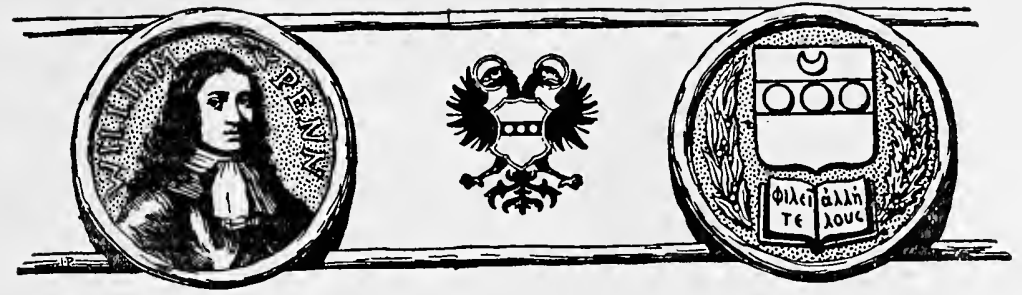

FOREWORD.

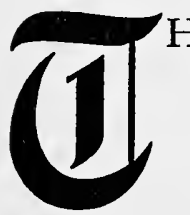

HE sources usually determine the stream. The beginnings of a movement generally contain a prophecy of its later development. For that reason it has been thought worth while to make a study of the origin of the present German element in York County. The position of Pennsylvania in the affairs of the nation and the position of York County in the affairs of the state, make it profitable to investigate the earliest beginnings of the strongest element in the county. The study has been fruitful for it has dealt with virgin soil.

It has not been possible in a single monograph like this to trace the history of these settlements beyond their very beginnings. Nor has the attempt been made to follow out all possible lines of investigation, such as the economic, the sociological, the political, the industrial, the religious, and the linguistic. To set forth the full history of the Germans in the county will require a series of volumes. The present treatise is merely a study preliminary to such a full presentation of their history. It has been regarded as sufficient to show in this treatise how those German settlements took their beginnings, and to set forth such characteristics of the original settlers and such features of the original settlements as will enable the reader to understand 
the relation of this element to the subsequent history of the county, to the general movement of Germans in this country, to the colonial history of the state of Pennsylvania, and to the general course of events in our national history. Our study therefore has barely covered two decades and has in no case carried us beyond the middle of the eighteenth century. But this brief span of years lies in the most important because the most formative period of our history.

The York County with which we deal is the county as bounded on the map of today. Other geographical expressions also are used with their present-day significance.

An effort has been made to weave the body of the text into the form of a continuous narrative and so far as possible to relegate to the footnotes all references to sources, all allusions merely incidental, and all details not directly relevant. Specific acknowledgment of all sources is made at the places where they are used and these are also collated in the Bibliography (Appendix D). The Blunston letters that are quoted or referred to are always found in the "Miscellaneous Manuscripts of York and Cumberland Counties, I738-1806" (see Bibliography) unless otherwise indicated.

GetTysburg, PA., April 30, I9I4. 


\section{CONTENTS.}

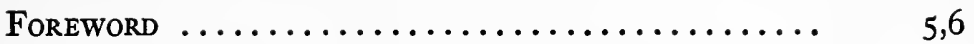

Table of Contents ..................... 7

Chapter I.-The First White Men in the County ... 9-20

Chapter II.-The First Settlers .............. 2I-36

Chapter III.-The First Settlement ........... 37-68

Chapter IV.-Other Early Settlements .......... 69-95

Chapter V.-Whence the Germans Came and Why . 96-123 Chapter VI.-Outstanding Characteristics ........ I24-I47 Chapter VII.-The Limestone Soil ........... I48-174 Chapter VIII.-Their Place in Pennsylvania History . I75-185 Chapter IX.-Their Place in General American His-

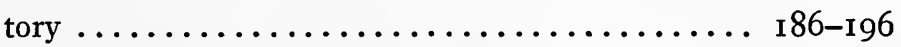
Appendix A.-Letter of Samuel Blunston ......... 197-202 Appendix B.-Signers of Letter to Maryland ....... 203, 204 Appendix C.-Inventory of Jacob Welshover's Estate . 205-207 Appendix D.-Bibliography . ............... 208-217 
1

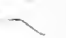




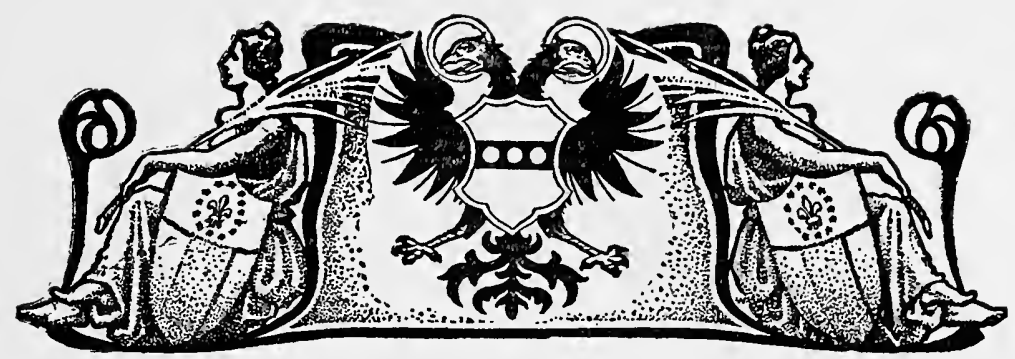

CHAPTER I.

The First White Men in the County.

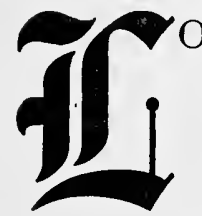

ONG before the white man began to make permanent settlements in what is now York County, its valleys were trodden by the pilgrim, the explorer, and the trader. Already in the first decade of the eighteenth century settlements had begun in Lancaster County just east of the Susquehanna River. At the same time or shortly before that settlements began to spring up on the Monocacy in Maryland and in the Shenandoah Valley of western Virginia. The settlers in these regions were for the most part Germans who had left their homes chiefly on account of religious persecutions. That there were German settlements in Virginia some years before the end of the seventeenth century is shown by an old French map ${ }^{1}$ of 1687 which marks the location of a German settlement at the headwaters of the Rappahannock River. This is also confirmed by an English map of about the same time which has the words "Teutsche Staat" on the upper Rappahannock, and on the upper James River points out "Meister

\footnotetext{
${ }^{1}$ Now in the collection of Dr. Julius F. Sachse of Philadelphia. See letter of Sachse, Feb. 10, 1907, to Wayland in Wayland's "German Element in the Shenandoah Valley," p. ro.
} 
Krugs plantasie." Furthermore in I699 Daniel Falckner, one of the pietists on the Wissahickon Creek, was sent to Germany as representative of the pietistic fraternity. One of the expressed objects of this trip to the Fatherland was to solicit aid and additional recruits so that the perfect number of forty could be kept intact and so that the fraternity could extend their usefulness in educating their neglected countrymen in Pennsylvania and Virginia. ${ }^{2}$

It was only natural that these German pioneers in the different colonies should early seek to communicate with one another. And so as a matter of fact they did. The common bonds of nationality and of religious interest soon operated to bring about intercourse and conference between the German sectarians of eastern Pennsylvania and those of Maryland and Virginia on the south. Letters were written and journeys were made. The journal of John Kelpius ${ }^{3}$ shows that on October 10, I704, that philosophical mystic wrote from the banks of the Wissahickon in Pennsylvania a twenty-two page German letter to Maria Elizabeth Gerber, ${ }^{4}$ a disciple of his in Virginia. But the religious enthusiasm of the sectarians was not satisfied with the interchange of letters. Visits were made for the purpose of exhorting and strengthening the brethren in the faith. Long preaching journeys were undertaken. The manuscript of Reverend Petrus Schäffer (written to Reverend August Hermann Francke) now in the archives at Halle shows that before the end of the seventeenth century, about the time that Falckner went to Germany, both Petrus

2 Sachse, "Curieuse Nachricht," p. 37; also Sachse, "German Pietists of Pennsylvania," I'694-r708, p. $96 \mathrm{f}$.

3 Journal now in the possession of Mr. Charles J. Wistar of Germantown, Philadelphia.

4 There were Gerbers also in Lancaster County; see Rupp's "History of Lancaster County," p. 189. 
Schäffer and Heinrich Bernhard Köster travelled from Pennsylvania to Virginia on such a mission. ${ }^{5}$ After German settlements had been made in the Carolinas in $1710^{6}$ the preaching and teaching trips of the Pennsylvania German sectarians extended beyond Virginia to what is now North Carolina. Thus in 1722 Michael Wohlfarth, a pietist from Germantown, journeyed on foot from Philadelphia by way of Conrad Beissel's hut on the Mühlbach and through the Valley of Virginia to preach a revival among the Germans in North Carolina. ${ }^{7}$

Now the route of these religious enthusiasts on their journeys from north to south was a well-marked one. It was the great natural avenue formed by the valley between the Blue Ridge and the Alleghany Mountains. This is the highway that from time immemorial had been used by the Indians in their wanderings from north to south or vice versa. It included the series of fertile valleys now known as the Cumberland, the Shenandoah, and the Virginia Valleys. The first white men to set foot upon these regions were the German pietists of Pennsylvania and Virginia. Before the close of the seventeenth century the German settlers, pilgrims, and explorers had begun to pass up and down over this great natural highway with its fertile soil and its well-watered bottoms and long before the middle of the eighteenth century the Germans were buying lands in the Shenandoah Valley and settling there as though it had been one of the outlying districts of the city of Philadelphia.

\footnotetext{
5 Sachse, "German Pietists of Pennsylvania," I694-1708, p. 289; also "Curieuse Nachricht," p. 37, footnote.

6 At Newbern, North Carolina, see Bernheim, "German Settlements and the Lutheran Church in the Carolinas," p. 67 ' ff.; also Williamson's "History of North Carolina."

7 Sachse, "German Sectarians of Pennsylvania," r708-r742, p. 80.
} 
York County is not a part of this great highway but for the pilgrims coming from Lancaster County and the counties east and northeast of Lancaster, York County is the gateway to the Cumberland and the Shenandoah Valleys. The German evangelists and pilgrims from eastern Pennsylvania when they set out to visit their brethren in the South would usually call upon their countrymen in Lancaster County and then crossing the Susquehanna River would make their way across the entire breadth of York County until they reached the Cumberland Valley. ${ }^{8}$ In doing this they followed the path of the Indian trail which led from a point on the Susquehanna afterwards known as Wrightsville, westward along the Kreutz Creek and across the Codorus Creek to a point one and one fourth miles beyond the present city of York and thence northwestward by MacAllister's Mill and through Wakely's (Moore's) Gap in the South Mountains to Carlisle on LeTorts Spring in the Cumberland Valley. Or else, instead of turning northwestward after leaving the site of York they continued southwestward and thus followed the entire course of the valley which extends across the width of the county from Wrightsville through York and Hanover and into Maryland. ${ }^{9}$ These were well marked paths. They were in almost constant use by the aborigines before the white men came to America as a thorough-pass from the wilderness in the south and west to the wilderness in the north and

8 Heinrich Sangmeister in his "Leben und Wandel" tells how he and his companion Brother Antonius left the Ephrata Cloister and reached the Cumberland Valley in this way. Sachse, German Sectarians, p. 345 .

O The diaries of the Moravians (now preserved at Bethlehem, Pa.) indicate that they usually employed the latter route in their missionary journeys. And in the Virginia Magazine, Vol. 12, p. 55, footnote, we have the general statement: "The first part of the journeys of these Moravian missionaries was always the same. From Bethlehem by way of Lebanon, Lancaster, York, Pa., Frederick and Hagerstown, Md., to the Potomac." 
east. Long before permanent settlements had been made along the courses of this route its paths were trodden by the German missionaries and pilgrims on their way to the great valley highway that led to their brethren in the south. And when the county of York began to be populated and the need of roads began to be felt, a large part of this old Indian trail which had furnished the route for the missionaries was constructed into the "Monacacy Road" (I739). With the construction of the "Shippensburg Road" in I749 and the "Carlisle Road" in I75 I, the several branches of the historic missionary route from the Susquehanna River to the Cumberland Valley disappeared entirely beneath the roadbed of the public highways. ${ }^{10}$ It is worthy of note that the Germans should have been the first white men to set foot upon these regions which were to be so largely settled by Germans less than half a century later and which were to furnish the outlet for so large a body of German immigration to the south and the west.

After the valleys of York County had been in use for some years as a thoroughfare for the German pilgrim, the explorer and the trader began to interest themselves in these districts. The first traders appeared shortly after the beginning of the eighteenth century. John Harris an Englishman settled at the site of Harrisburg in 1705 . He opened a trading station and carried on an extensive business with the Indians on both sides of the Susquehanna River both north and south of his station. The Indians in York County were situated chiefly along the river and Harris purchased large quantities of skins and furs from them. But the chief pioneer Indian traders along the lower Susquehanna were French Canadians. Prominent

10 See, for example, Gibson's "History of York County," p. 32 I f. 
among them are the names of Martin Chartier, Peter Chartier, Peter Bazaillon, and James LeTort. They all had their stations on the east side of the river but carried on a large business in trading with the Indians west of the river.

The first man to explore the county was a representative of the German Mennonites from Switzerland. It was the explorations of Lewis Michelle from Bern that led to the first Pennsylvania survey within the present limits of York County. Michelle (or Mitchel) was employed by his fellow countrymen and co-religionists of the canton of Bern and sent to America in 1703 or 1704 to search for a convenient tract of vacant land in Pennsylvania, Virginia, or Carolina, that might serve as a suitable place for the settlement of a Swiss Mennonite colony. ${ }^{11}$ In the course of this search he came in 1706 to the Conestoga region in the western part of Lancaster County. On February 24, I707, the Conestoga Indians made formal complaint against Michelle for his wanderings among their lands, and for having pressed their people into service as guides and assistants. ${ }^{12}$

Michelle was a miner according to the testimony of Governor Evans, and for that reason received the encouragement and support of the Pennsylvania government in his explorations. ${ }^{13}$ For the early colonial governments

11 A. Stapleton in his "Memorials of the Hugenots in America," speaking of the French traders in the Conestoga Valley of Lancaster County, says, p. 89: "It is worthy of note that Lewis Mitchelle the advance agent and prospector of the Bernese Mennonites, spent a number of years with these traders $(1703-1707)$ on terms of intimacy and was accused by the authorities on the occasion of a misunderstanding of having led the Frenchmen here."

12 Colonial Records, II : 404 f. Also Rupp's "Lancaster County," p. $54 \mathrm{f}$. 13 "The Governor added that he found he (i. e., Michelle) had some notion of mines, and had his thoughts much bent that way; that he was 
were always keenly on the alert for even the slightest indication of mineral wealth in the soil of the new land and they always encouraged the search for mines, at the same time exercising care to pre-empt for themselves the exclusive rights of exploitation. At one time Governor Evans was strongly suspected of conniving with Michelle to secure personal gain from the discoveries of this roving prospector. In I 708 William Penn wrote from England to James Logan, his secretary: "Remember the mines which the Governor yet makes a secret, even to thee and all the world but himself and Michelle."

But the explorations of Michelle west of the Susquehanna bore their first real fruit under the governorship of Sir William Keith, a shrewd and enterprising Scotchman who was quick to develop the natural resources of the province and who also was not beyond turning those resources partly to his own personal benefit. Governor Keith was the first governor to lead the proprietary surveyors beyond the Susquehanna River and into the present limits of York County. This first survey was made in 1722 and was one of two surveys made within the present limits of our county in the month of April of that year. Governor Keith's survey was the first and was made secretly on April 4 and 5. The governor afterwards gave as his reason for making this survey that he wished to prevent the obnoxious intrusions of the Marylanders in this part of Pennsylvania soil. The circumstances under which this survey was made throw much light on the historical background of the earliest German settlements in the county.

willing to let him proceed, and had not discouraged him; that he advised him to take some Indians with him; that of the persons before mentioned, the Governor had ordered two that he could confide in to be there, that he might have a full account of their proceedings." Col. Rec., II: 405. 
Sir William, it would seem, was amply justified in the swift and sudden measures he took to secure the territory west of the river. Delay might have been costly. The governor explained his action at the meeting of the Provincial Council in Philadelphia on April 16, 1722, in these words:

Upon some information I lately received that the Indians were like to be disturbed by the Secret and Underhand Practices of Persons, both from Mary Land and this Place, who under the Pretence of finding a Copper Mine, were about to Survey and take up Lands on the other side of the River Sasquehannah, contrary to a former Order of this Government; I not only sent up a Special Messenger with a Writ under the Lesser Seal to prevent them, but took this Occasion to go towards the Upper parts of Chester County myself in order to Locate a small quantity of Land unto which I had purchased an original Proprietary Right; And understanding further upon the Road, that some Persons were actually come with a Mary Land Right to Survey Lands upon Sasquehannah, fifteen miles above Conestoga, I pursued my course directly thither, and happily arrived but a very few hours in time to prevent the Execution of their Design. Having the Surveyor General of this Province along with me in Company, after a little Consideration, I ordered him to Locate and Survey some part of the Right I possessed, viz.; only five hundred acres upon that Spot on the other Side Sasquehannah, which was like to prove a Bone of Contention, and breed so much mischief, and he did so accordingly upon the 4th and 5th days of this Instant April, after which I returned to Conestogoe, in order to discourse with the Indians upon what had happened. ${ }^{14}$

He was none too soon with his scheme to forestall the Maryland survey. For a company of people under Maryland authority and in partnership with the Maryland Proprietor was busy sinking shafts and prospecting for mines

14 Col. Rec., II: r6o. 
in that region. They were already operating a mine farther south along the Susquehanna and had designs upon the very tract which Governor Keith had reserved. Among the unpublished Calvert Papers ${ }^{15}$ is the certificate of a survey of 200 acres made April 24, I 722, by Deputy Surveyor John Dorsey of Maryland "by virtue of a warrant granted unto Philip Syng and Thomas Browne both of the City of Philadelphia in the Province of Pennsylvania out of his Lordships Land Office bearing date of March 28th, I 722." This tract was known as "Partner's Adventure." Another of the Calvert Papers gives an account of the examination of Philip Syng, ${ }^{16}$ May 28, 1722 , before the Governor and Council of Pennsylvania, on the charge of having surveyed land under a Maryland warrant within the bounds of the Keith tract. ${ }^{17}$ The evidence in this examination shows that the survey on account of which Syng was apprehended and committed was the Partner's Adventure of 200 acres surveyed by John Dorsey. For this a warrant had been issued as early as March 28, I722. Governor Keith therefore was just in time with his survey of April 4 and 5 to make good the Pennsylvania claim.

The keen disappointment of the Marylanders at their exclusion from this region and their further designs upon the land are manifest from the following letter of July I9, I 722, from the Secretary Philemon Lloyd to Lord Baltimore and Co-Partners in London:

I did myself the honor of writing to you of June I $722 \ldots$ have seen Roach, Sing and Brown; the 3 remaining partners in the

15 No. 274. In the Maryland Historical Society, Baltimore, Md.

16 No. 273. The warrant for his arrest (among the Calvert Papers) is dated May 27, r722, and designates Philip Syng as a silversmith.

17 See also Col. Rec., III: 176 . 
adventure. They seem very much disconcerted at the loss of their mine upon Susquehannah, of which I sent the ... in my (last). I have received at their hands 2 ps of Oar: the one copper and Iron the other silver and iron. The mine is so strictly guarded that they tell me they could not possibly gett any more, (but) promise a larger quantity against the time that I come up to them. Which I design in six or seven days at the farthest and will then go to the place where they have several men at work in opening a copper mine, much lower down in Maryland.

Gentlemen, According to the worth and circumstances of this and other mines, I shall find myself under a necessity of doeing something with the discoverers rather than be wholly shut out from these first undertakings in case the land be allready taken up; but if not I will then lay warrants wherever I can hear of any probability of a mine. Schylers and the mine upon the Susquehannah hath made such a noise in the world, that the woods are now full of mine hunters. Many discoveries are already made; but the worth of them unknown untill shafts shall be sunk to find out the largeness and quality of the vein. Upon which account I humbly propose: [here follow four propositions to encourage the finding and reporting of mines]

Publick reports concerning the value of the mine upon Susquehannah are various and uncertain, especially of late, they have given out that the Governor \&c after a great deal of pains and cost are about to quit it. On the other hand Sing, Roach, and Brown tell me, that such reports are spread abroad on purpose to give . . . oppertunity of conveying away the oar with little or no notice, they allso . . . they came from Philadelphia, 7 Waggons were in waiting near . . . transport the oar down to New Castle which is 50 miles distance, \& I had . . . some persons tell me allso that a much better way be ... to the head of one of our rivers with 30 miles land carriage.

I am not a little concerned that the reserve of I0,000 Acres formerly advised of hath not been executed. I know not by what means the Pennsylvanians had notice of it, but before our surveyor 
went up (he was out of the way for some time after I sent the warrant to him) they had posted souldiers all about the woods So that our officer dared not to go and execute the warrant. However I am resolved to be up among them and to lay the reserve if possible; notwithstanding if Sir William Keith hath laid out all the adjacent lands for young Penn by name of Springetts Bury qr 75,520 Acres though I believe twice that quantity may be thrust into those bounds, by reason of the terms more or less; as you will see they are there made use of in the enclosed copy of warrant.

As soon as Sing Roach \&c went up; a warrant was issued out by Sir William and Sing taken upon the mine: thence carried to Philadelphia and committed to the city goal, as you will perceive by the inclosed papers which I have purposely transmitted that the rigorous methods of these people may be known. I design however to make a survey there with all imaginable secrecy, but should be heartily glad if a proper instrument were sent over (for) the taking the Lat. of the place, or that some publick directions were given to the Government for the making an (exact) discovery of the line of 40 North. ${ }^{18}$

The second survey was made on April ro and I I, and covered much the same territory as Keith's survey. It was made upon the order of Penn's Commissioners of Property. The Commissioners afterwards gave as their reason for making the survey that they had been " informed that the Governor (Sir William Keith) had gone towards Susquehanna and had taken Jacob Taylor with him, which gave them some apprehension of a design which he might have on a parcel of land on the other (west) side of the Susquehanna where was supposed to be a copper mine."19 The region covered by these surveys afterwards for some years bore the title "Keith's Mine Tract." There can be

18 The published Calvert Papers, No. 2, p. 25 ff. "Fund Publications." 19 Minutes of the meeting of the Commissioners of Property held in Philadelphia, April r6, 1722. 
little doubt therefore that the first authorized survey in York County was incited by the hope of finding some mineral or ore, either copper or gold, and that attention was directed to this region by the explorations of Lewis Michelle, the Mennonite miner, whose prospecting for mines in 1706 had led to the formal complaint of the Conestoga Indians. It is not at all surprising that Governor Keith was well informed of the movements of this advance agent of the Mennonites. For he was keenly interested in the development of the natural resources of his province and he also seems to have been generally on favoring terms with the Germans. For it was he who in 1723, of his own motion and with the subsequent disapproval of the Proprietary, placed the Germans from Schoharie, New York, in the Tulpehocken Valley.

Just how much of the present area of York County was covered by the explorations of Michelle it is not possible to ascertain but it seems certain that they extended over the present townships bordering on the river from Newberry south, and at times must have penetrated as far westward as the Cumberland Valley. ${ }^{20}$ Much of this territory afterwards became very familiar soil, not only to the German Mennonites but also to Germans of other religious faiths.

20 For the formal complaint of the Indians (supra, p. 5) stated that "divers Europeans, namely: Mitchel (a Swiss), Peter Bezalion, James le Tort, Martin Chartiere, the French glover of Philadelphia, Flranck, a young man of Canada, who was lately taken up here, being all French men, and one from Virginia, who also spoke French, had seated themselves and built houses upon the branches of the Patowmack, within this government, and pretended that they were in search of some mineral or Ore, \&c." Col. Rec., II: 403 f. 


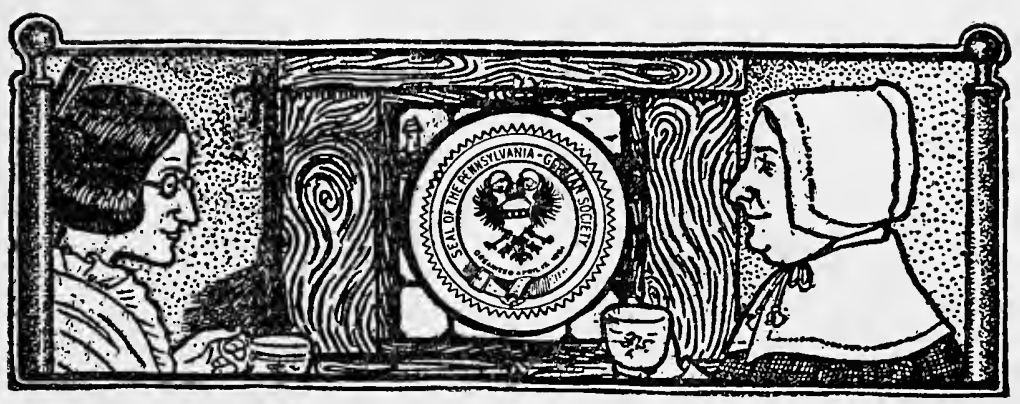

CHAPTER II.

\section{The First Settlers.}

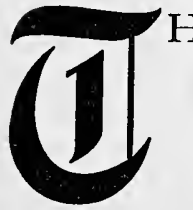

$\mathrm{HE}$ earliest attempts at settlement within the present limits of the county were made before the land had been purchased from the Indians, hence before any kind of title could be given according to established usage. Those who thus entered unpurchased Indian lands were known as squatters. The first white squatter on the territory west of the Susquehanna was John Grist (otherwise Crist, Krist, Greist). He was an Englishman who came to York County from Hempfield Township, Lancaster County, in I7I9 or $1720 .{ }^{1}$ Grist was accompanied in this move by several other persons. They settled near the mouth of Kreutz Creek known in Keith's survey of I 722

1 The fact referred to in footnote 20 of Chapter $I$ that Michelle and others had, according to testimony of the Indians in 1707 , "seated themselves and built houses upon the branches of the Potowmack within this Government" can hardly be taken to mean that they were the first squatters west of the Susquehanna. For they were merely prospectors and adventurers. They certainly made no substantial improvements such as would constitute their houses a "settlement" or "plantation." They quickly moved on to other fields of exploration. In fact Michelle had already many weeks before the complaint of the Indians moved on to Maryland soil. Col. Rec., II : 404 . 
as "White Oak Branch." We are able now to determine very definitely the exact spot where Grist settled and planted his corn. Two drafts of the Keith survey are in existence, one in York and one in the Department of Internal Affairs at Harrisburg. The draft at Harrisburg identifies the settlement of John Grist with the habitation of Captain Beaver, an Indian. The draft in York fixes the habitation of Captain Beaver at about the spot now covered by the Pennsylvania Railroad Station at Wrightsville. This then was the location of Grist's house and improvement. ${ }^{2}$

But the new settlement was very short-lived. Grist soon came into conflict with the Indians who resented his intrusion upon their domain. And in $172 \mathrm{I}$, upon complaint of the Indians and after repeated warnings and threats from the Commissioners of Property, he was fined and imprisoned in the jail at Philadelphia and was given his liberty only out of compassion for his poor family and on condition that he and his "accomplices" would remove at once from the west side of the river and that he would be placed under heavy bond for his good behavior. This was " judged absolutely necessary for the quiet of the Indians, and also to prevent such audacious behavior in contempt of the authority of this government in the time to come."3

2 It is evidently not accurate when Rupp says ("History of Lancaster and York Counties," p. 529') that Grist was accompanied by "divers other families," for the provincial authorities deal with Grist alone and the "divers other persons" mentioned in the Colonial Records were probably only his associates in labor.

${ }^{3}$ Col. Rec., III : 137 . This same John Grist afterwards, in I'738, settled 298 acres on the Bermudian Creek in Manchester Township in the western part of York County, receiving his final warrants for the same on July 23, r742 and October 25, r747. Lancaster County Records. 
It might seem that this treatment was severe enough to serve its purpose of preventing any further attempts at squatting west of the Susquehanna. Nevertheless it was not long until others crossed the river from Lancaster County and settled on the west bank. In 1722, shortly after making the survey of Keith's Mine Tract, Governor Keith made a treaty with the Indians guaranteeing them the territory south and west of the Susquehanna for their exclusive possession. But in spite of this agreement it was shortly thereafter, perhaps even beginning in that same year, that three Englishmen, Edward Parnell, Paul Williams, and Jefferey Sumerford, and one German, Michael Tanner, ${ }^{4}$ took up their abodes on the west side of the river opposite the Indian town of Conojahela, about three and a half miles south of the former settlement of John Grist. ${ }^{5}$ Here these intruders remained until late in the year 1727 and that too not without the knowledge of the Pennsylvania authorities. ${ }^{6}$ But in the fall of 1727 upon the complaint of the Conestoga Indians they were removed by order of the deputy governor and council. And again for

4 Tanner could not have joined the rest until 1727 , for he did not reach the port of Philadelphia until September $27^{\text {th }}$ of that year.

5 It is a confusion of facts when Carter and Glossbrenner, the first historians of the County, assert that these men had come from Maryland and were known as "the Maryland intruders." They were indeed intruders upon the territory of the Indians but they had come from Pennsylvania.

6 For Wright and Blunston in their report to Governor Gordon in 1732. state that until about two years before 1729 Parnell and the others had been settled west of the river and "for several years had paid uninterrupted acknowledgement to this Province." Archives, I: 364 and Col. Rec., III: 470. The deposition of Tobias Hendricks (Dec., r732) states that "during the continuance of the said Parnel, Williams and Others there, they paid taxes to this Province, Applied there for Justice, and in all cases acknowledged themselves Inhabitants of Pensylvania, until they were $\mathrm{Re}$ moved from thence by Order of the Governor of Pensylvania, at the Request of the Conestogoe Indians." Archives, I: 362 . 
a short interval the lands west of the broad river lay vacant for the exclusive convenience of the Indians.

By this time it had become evident that no permanent or successful settlement could be made west of the river without securing either the consent of the Indians or the authorization of the colonial government. Accordingly the next effort at pioneer improvement on the new soil proceeds with the consent of the secretary of the province. This first authorized settlement within the present limits of our county was made in I728, a few months before Lancaster County was organized and separated from Chester County. In the summer of that year John Hendricks removed from the banks of the Conestoga about three miles north of the Susquehanna and under the authority of government settled west of the Susquehanna upon the tracts from which John Grist and his companions had been compelled to remove in $\mathrm{I} 72 \mathrm{I}$. The circumstances attending this settlement will help us to understand something of the conditions under which the earliest settlements in York County took their beginnings.

Hendricks's removal to the west side of the river had been under contemplation for several years. The hunting-trips of Hendricks and his relations had often taken them across the river, and thus they had become fairly familiar with the soil on the west bank. Early in the year I 727 John Hendricks had applied to James Logan, secretary of the Province, for permission to take up land and settle west of the river. At the same time a similar application was made by Joseph Chapham. Hendricks told Logan that the Indians west of the river were desirous that that he should settle there. Now Logan had heard that some people from Maryland were about to make surveys 
on those lands. Accordingly upon the application of Hendricks and Chapham, Logan ordered Samuel Blunston, a magistrate located on the east bank of the Susquehanna, to survey a tract west of the river opposite Hempfield embracing about $\mathrm{I}, 000$ or $\mathrm{I}, 500$ acres. This was to be surveyed to William Penn, grandson of the first proprietor, and was to be regarded as part of the 10,000 acres devised by the proprietor to his grandson. It was hoped that this arrangement would both forestall any claim to the land that the Marylanders might put forth and at the same time give no offense to the Indians. Logan also instructed Blunston that if Hendricks and Chapham could secure the consent of the Indians, they together with Hendricks's brother James should be permitted to make settlement on part of the tract west of the river.

In July, 1727 , Blunston crossed the river and marked the four corners of a tract such as he had been ordered to survey. The actual survey was not then made because, as he explained, "at that time the weeds being so high we could not chain it nor carry an instrument to any purpose." Meanwhile Chapham had given up his intention of settling there and had moved to Carolina. Moreover the attitude of the Indians had become such that John and James Hendricks did not regard it as a safe venture to settle west of the river. For their brother Henry together with one Thomas Linvil had during the summer settled as squatters on the Codorus Creek at a point twelve miles west of the Susquehanna but the violent opposition of the Indians had forced them to withdraw. Thus no authorized settlement was effected in that year.

But John Hendricks persisted. In the fall of the year I 727 he appealed to Logan a second time for permission 
to settle on the tract which had been marked off. But he was now informed that since the Indians insisted upon their rights and were determined that there should be no settlements of whites within their domain, no such permission as Hendricks sought could be granted by the authorities. However during the year I 728 the Indians began to grow cool in the assertion of their rights as over against the Pennsylvanians. For they began to realize from sad experience that if they hindered the citizens of Pennsylvania from settling in those parts the Marylanders would occupy them by force without any consideration for the rights or feelings of the Indians. Marking this change of sentiment among the aborigines John Hendricks during the summer of 1728 removed across the river with his wife Rebecca and took up his abode upon the former plantation of John Grist. ${ }^{7}$ This he did without any further license than that which he had already received, namely, permission of the secretary of the Province to settle on a part of the tract marked off for William Penn, on condition that he first secure the consent of the Indians. As the Indians never objected to Hendricks's settlement there this settlement was always regarded by the authorities as legal and authorized. ${ }^{8}$ The tract on

7 Local historians following Carter and Glossbrenner have always assigned 1729 as the date when both John and James Hendricks settled west of the river. But these statements are erroneous, as is evident from the clear and reliable account of Samuel Blunston (see Appendix $A$ ) and from the provisional warrant issued by Thomas Penn in I733 (vide infra, p. 27). This date is also attested by a third document, a letter from Samuel Blunston to Richard Peters dated March 25, I740, in which he says: "Inclosed herewith is a draught of the tract of land I bought of John Hendricks ... the land was surveyed to and settled by John Hendricks in the year $\mathbf{1} 728$ by order and consent of the proprietary commissioners." Penna. Archives, Second Series, Vol. VII, p. 219.

8 For example, the Provincial Council makes reference in 1737 to " John 
which Hendricks lived was formally surveyed to him by Blunston during the last week of November, I729. It included 600 acres and constituted about one half, "the uper side and best part," of the tract originally marked off for the proprietor. ${ }^{9}$

The proprietary warrant for this survey and settlement was not issued until March 20, I733. It was then issued on behalf of John Hendricks, James Hendricks, and Joshua Minshall. For John Hendricks did not long enjoy the distinction of being the only authorized settler west of the river. About the year I73 I James Hendricks, his brother, came and settled on a part of the tract on which John lived "it always being understood to be their equal right." But in the early spring of 1732 James was accidentally shot and killed by his father while they were hunting turkeys, and his widow sold out her rights in the property to Joshua Minshall. Minshall settled on the land which he had thus bought and when Thomas Penn the following spring approved the survey and issued a conditional grant it read as follows:

Wheras upon the Application of John \& James Hendricks \& some others, Inhabitants of Pensilvania the Commissioners of Property did in the year I 728 order Samuel Blunston to lay out a Tract of Land of Twelve hundred Acres lying on the West Side of Susquehannah opposite to Hempfield; which Land was then settled by the said Parties, and is now in the Possession of the said John Hendricks and Joshua Minshall, who holds in right of the said

Hendricks, who for some years lived on the west side of Susquehannah, on a Tract of Land laid out to him by the Authority of this Government." Col. Rec., IV: 150.

${ }^{9}$ The draft of this survey was promised to Logan (as per Blunston's Letter). If it was ever made it has since been lost. But the location of the tract is well known, being identical with the former plantation of John Grist. 
James Hendricks; and it appearing to me that the said John Hendricks \& Joshua Minshall are settled upon the said Land by regular Surveys-ordered to be made in the Year I728 of which I approve and will order a Patent or Patents to be drawn for that share of the Land laid out to the said John and James Hendricks to John Hendricks and Joshua Minshall as soon as the Indian Claim thereon shall be satisfied-on the same Terms other Lands in the County of Lancaster shall be granted. Philadelphia, 2oth March $1732 / 3 \cdot{ }^{10}$

It has usually been assumed that these first settlers within the present limits of York County were Englishmen. It is impossible to trace them farther back than their settlement in Lancaster County, and in the absence of information to the contrary they have been regarded as English. The earliest historians of the county, Carter'and Glossbrenner, in their "History of York County" take the English nationality of the Hendrickses for granted. "The earliest settlers were English; these were, however, soon succeeded by vast numbers of German immigrants." In this they are followed implicitly by all the other historians of the county from Day to Gibson and Prowell. Thus Day quotes the above authors with approval and remarks: "John and James Hendricks in the spring of I 729, made the first settlement. ... They were soon followed by other families, principally Germans, who settled around them within ten or twelve miles."11 Other writers have been content to accept the statement of these early authorities on the history of the county. Their conclusion is doubtless drawn from the associations and the names of the Hendrickses.

They came from an English Quaker community in the

10 Now in the Land Office at Harrisburg.

11 Historical Collections of the State of Pennsylvania, p. 693. 
township of Conestoga. Here in I7 55 "James Hendricks and company" had taken up a tract of 1,100 acres on the Conestoga Creek. This tract was divided out among the members of the "company" and became a strong Quaker community. This James Hendricks was the father of James and John, the earliest settlers west of the river, and associated with him in his "company" were such men as Jeremy Langhorne, Thomas Baldwin, David Priest, and Tobias Hendricks. These families were closely intermarried. Thus John Hendricks was married to Rebecca, daughter of Thomas Baldwin. This would seem to indicate also religious affinity between the Hendrickses and the Baldwins, who were English Quakers. ${ }^{12}$

Moreover their immediate associates east of the river were in all cases English. The elder James Hendricks kept an ordinary where the highway from Philadelphia and Lancaster forded the Conestoga Creek. When the Hendrickses migrated west of the river their property on the Conestoga was bought by an Englishman, John Postlethwait. John Hendricks's first petition to settle west of the river was made jointly with Joseph Chapham. Here again the name is unmistakably English as is also the case with Thomas Linvil, the man associated with Henry Hendricks, brother of John and James, in the effort made in I 727 to affect a settlement on the Codorus twelve miles west of the Susquehanna. Moreover the widow of James Hendricks sold out her rights to the English Quaker, Joshua Minshall. And afterwards when John Hendricks removed from Hellam Township to Manchester Township he took up land adjoining Francis Worley, another name prominent among the Quakers. These close asso-

12 Rebecca Hendricks in her deposition of Dec. 29, $\mathbf{1 7 3 2}$, is specifically designated "one of the People called Quakers." Archives, I: $36 \mathrm{I}$ f. 
ciations of the Hendrickses with the Quakers may be held to justify the conclusion that they were themselves Quakers and Englishmen. It can hardly be argued as against this conclusion that John Hendricks took up arms and participated actively in the border warfare between the Marylanders and the Pennsylvanians. For it is a well-known fact that in spite of their scruples against armed force, the hardy pioneer Quakers did sometimes in cases of emergency and for reasons of self-defense join in the appeal to arms.

But when consideration is had for the names of these earliest settlers themselves the argument for their English nationality seems less conclusive. The name Hendricks may be either English or German. It is of frequent occurrence among the pioneer Germans of Pennsylvania. The name Hendrick appears repeatedly, both as Christian name and as surname, in the lists of German immigrants who arrived at the port of Philadelphia between 1727 and $1775 .^{13}$ The transition from Hendrick to Hendricks, like that from Myer to Myers, was easy and quite usual. And although John and James Hendricks were located on the banks of the Conestoga before these lists of German immigrants began to be kept in Philadelphia, nevertheless it is an established fact that there were Germans in Pennsylvania by the name of Hendricks (not merely Hendrick) early in the eighteenth century. For in the list of Germans naturalized by act of the Assembly September 29, I $709,{ }^{14}$ are found the names of Wilhelm Hendricks, Henrich Hen-

13 Instances of such names are pointed out by H. L. Fisher in Gibson's "History of York County," p. 222. These lists of immigrants are to be seen in the Division of Public Records at Harrisburg. They were edited and published in substantially correct form in 18.56 by Professor I. Daniel Rupp, Rupp's "Collection of Thirty Thousand Names, etc."

14 Col. Rec., II : 493. 
dricks, Gerhart Hendricks, and Lorentz Hendricks. ${ }^{15}$ So far therefore as the family name of John and James Hendricks is concerned it is altogether possible that they were Germans.

Nor does the argument from their Christian names exclude the possibility of the German nationality of these first settlers. The Christian name James is indeed a good Quaker name and may be regarded as a strong indication of English heritage. For it occurs quite often among the kin of the pioneer settlers west of the Susquehanna. Their father was named James. And John had a son named James. ${ }^{16}$ But too much weight must not be attached to the inference from names alone as they occurred in those days of commingling races and languages. For as a matter of fact, in the second generation of Germans in America the name James does sometimes occur. And it may perhaps have occurred, by translation from the German, even in the first generation. For instance, as early as 1738 , at the organization of the German Baptist Church of the Little Conewago, one of the first elders of the Church bears the name James Hendrick. ${ }^{17}$

15 Rupp's "Collection," p. 43r. Michael Hendricks paid the yearly quitrent in Frederick Township, Philadelphia County, before 1734. Rupp's "Collection," p. 472.

${ }_{16}$ There was a James Hendricks in the western part of Lancaster County even after the death of James the brother of John Hendricks in 1732. He was connected with the first use of violence in the border diffculties west of the river. He was a carpenter, lived east of the river, and was employed by James Patterson in 1733 to make trips across the river to look after Patterson's horses there. We have two depositions made by him. In the one he is called a Quaker and makes affirmation (Nov. 25, r732). In the other he takes oath (Apr. 7, 1733). In both cases he makes his mark for a signature. Archives, I: 348 f. and 399 f. Also Col. Rec., 4: 6.55 .

17 See Falkenstein, "History of the German Baptist Brethren Church," p. 97 . 
Moreover it is a significant fact that James Logan in a letter to Samuel Blunston of May IO, I $727,{ }^{18}$ when he has occasion incidentally to refer to the younger James Hendricks erroneously calls him Hendrick Hendricks. This is a purely German name and was the correct name of another brother of James and John. Samuel Blunston afterwards calls this third brother Henry, which is but the English translation of Hendrick. Then too, in the course of their correspondence both Logan and Blunston refer to the father of James and John as Jacobus. This is the German for James and this fact taken in connection with the occurrence of the German name Hendrick among the sons of Jacobus raises a high degree of presumption in favor of the German nationality of these Hendrickses.

Several years later when the Germans west of the river felt that as a class they were being treated with injustice and subjected to indignities they united among themselves to assert their rights and on this occasion their principal leaders and spokesmen were two men named Henry Hendricks and Michael Tanner. These Samuel Blunston speaks of as "the most principal Note among those Germans."19 The identity of this Henry Hendricks with the Henry Hendricks who was a son of Jacobus Hendricks cannot be proved beyond doubt, but neither can it be successfully denied. It is, however, quite conceivable that Henry Hendricks, son of Jacobus, having made an unsuccessful effort in 1727 to settle on the banks of the Codorus, should have repeated the effort after his brothers had succeeded, that he should have been among the first to settle in that region when settlers began to crowd into it, and that this priority as well as his former English associations

18 See Appendix $A$.

19 Col. Rec., IV : 57 and 75. 
should have marked him together with Michael Tanner, another of the earliest settlers, as leaders among their countrymen.

A similar inference may be drawn from the conduct of John Hendricks after he settled on the west bank of the river. For some years he was quite content and loyal to the Pennsylvania government under whose authority he had settled there. But then he became dissatisfied with the amount and the location of the land which had been assigned to him. In the spring of $\mathrm{I} 735$ he appeared before the proprietaries and complained of the "unfair and dishonest usage" he had received at the hands of John Wright and Samuel Blunston in relation to the land west of the Susquehanna. This was the occasion of Blunston's informing correspondence cited above. Blunston's explanations and endeavors evidently did not satisfy Hendricks for from this time forth he sympathizes warmly with the Marylanders. In I 736 we find him harboring them on his plantation and giving them aid in their aggressions. And in January, I737, we find him imprisoned in the jail at Lancaster for "having unhappily engaged himself on the side of Maryland and been concerned in some of their late riots." ${ }^{20}$ It is highly improbable that if John Hendricks had been an English Quaker in good standing he would have manifested such violent opposition to the Quaker government or such acrimony against such prominent individuals among the Quakers as were John Wright and Samuel Blunston. Nor would it have been necessary for these Friends to bring about his imprisonment and to bind him to keep the peace. This would have been a very unusual proceeding of Friends against a Friend. The prob-

20 Col. Rec., IV: 150. 
ability is that if John was not a German he was at least not bound to the English Quakers of Lancaster County with such strong bonds of intimacy and nationality that they could not be severed.

Nevertheless before the Hendrickses crossed the Susquehanna they were evidently regarded as Englishmen by their fellow-citizens in Chester County. For in an old assessment list ${ }^{21}$ for "Conestoga," Chester County, which gives the names of all the inhabitants of the Conestoga district in the year I7 8 together with the rate for each, the inhabitants are distinguished as "English" and "Dutch." Here we find the names of James Hendricks and John Hendricks listed among the "English inhabitants."

A similar inference may be drawn from the case of the Tobias Hendricks mentioned above as one of the members of "James Hendricks and company" settled on the Conestoga in 17 I 5. Here the names, both Christian and surname, might be either English or German..$^{22}$ But this Tobias Hendricks was certainly regarded as English, for he became one of the magistrates of the peace for Lancaster County about $1727^{23}$ and served repeatedly in that capacity. His signature, still to be found on many documents in the Division of Public Records at Harrisburg, is always in English script. From the appearance of his signature in 1737 and from the fact that he died as an old man in 1739 he seems to have belonged to the generation

21 In the court house at West Chester. Copied by Gilbert Cope, Esq., and published in Egle's "Notes and Queries," Second Series, p. r3 1 .

22 The Christian name Tobias is of frequent occurrence among the Germans of Pennsylvania and John Tobias is the full name of a German who

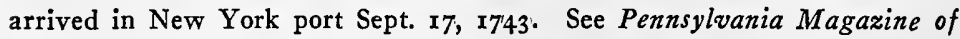
History and Biography, Vol. 33, p. 232.

23 According to his own affirmation. Archives, I: 362 . 
of the elder James Hendricks and was probably his brother. ${ }^{24}$

But here again midst the conclusive evidence for the English nationality of Tobias Hendricks there are clear indications of close relationship with the Germans. For Tobias Hendricks, Jr., second son of the magistrate, very early associated himself with the Germans of York County in religious affairs. He was one of the founders of the German Lutheran Congregation of the Codorus. In the baptismal records of that Church his name appears as one of the heads of families in that congregation. All the other members of the Church were pure Germans. But it is a significant fact that a slight distinction is made in the Church Record between Tobias Hendricks and the other members of the Church. Pastor Stöver, who kept the record, made all the entries in deep German script with the sole exception of the entry concerning Hendricks. His name is written in English script. The words of the entry are written in the German language and in German script but the English (or Latin) name of one of the children baptized is also in English script like the superscription "Tobias Hendricks." 25 This is a clear indica-

${ }^{24} \mathrm{He}$ died in the Cumberland Valley west of the river in Nov. 1739 , leaving a wife, Catherine, one daughter, Rebecca, and six sons. Egle's "Notes and Queries," Vol. II, 1896, p. 264. He was the ancestor of VicePresident Thomas A. Hendrix.

25 This record is in the possession of Pastor Enders of York. The entry referred to is as follows (the words in English script are here in italic):

\section{Tobias Hendrick}

Geb.

Getauft

[Here are records of baptisms of two sons, Joh. Jacob and Joh., and two daughters,

Elizabetha and Rebecca.]

I 744

Jan. 30.-Eine tochter Veronica zeug. Joh: Wolf.-April 15. 
36 German Element in York County, Pa.

tion that Tobias Hendricks, though associated with the Germans in their worship, was nevertheless regarded by Pastor Stöver as English.

What conclusion may we draw from these considerations? It is highly probable, but remains without positive proof, that these Hendrickses were of German descent, that their ancestors one or two generations previous were Mennonites in Switzerland or in the Rhine Valley and had fled before persecution and found refuge in England; that there they quickly associated themselves with their English brethren in the faith, the Quakers, and with them came to America. In this case they might be called Englishmen of German descent, and this would account for their German spirit of enterprise in pushing across the Susquehanna and locating where they did, while at the same time it would account for their English associations and the English form of their Christian names. Certain it is that soon after their location in York County the Hendrickses were close associates of the Germans who followed them into the county. They sympathized with them in times of adversity and coöperated with them in matters of religion. But while there were these strong bonds of sympathy and coöperation, perhaps even ties of blood between these pioneer Hendrickses and the early Germans in the county, nevertheless the places from which they came, their associates before their migration, together with the other evidence in the case, seem to leave little room for doubt that John and James Hendricks were regarded as Englishmen when they crossed the Susquehanna and that the honor of the first authorized settlements in York County cannot be claimed for the pure Germans. 


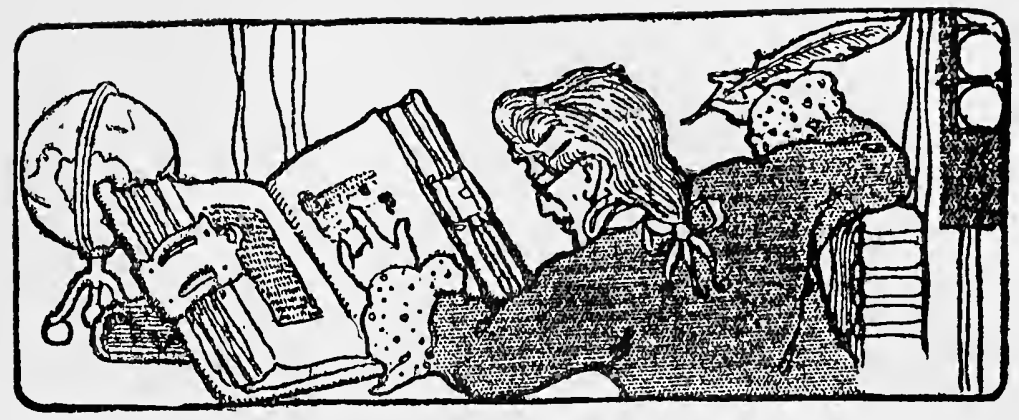

CHAPTER III.

The First Settlement.

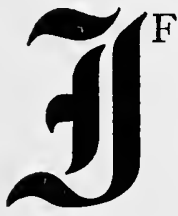

F the first individual settler in the county was not a German the first community of settlements did undoubtedly consist of German settlers and those parts of the county which were first tamed and subdued to the purposes of civilization have from the beginning borne the stamp of German language and culture.

It was in that same valley of the Kreutz Creek where the Hendrickses were settled and where unsuccessful efforts at permanent settlement had previously been made that the first stream of newcomers from the eastern side of the Susquehanna deposited itself. It followed very closely upon the settlement of John Hendricks in 1728. Even before that settlement was consummated many of the settlers east of the river had begun to manifest a desire to settle on the west bank. The Shawannah Indians of the village opposite Hempfield had removed into the interior. The false impression had got abroad among the people east of the river that the Indians of the Five Nations had resigned their claims to the lands on this part of the Susquehanna, and a letter of August IO, I727, from James 
Logan to Samuel Blunston indicates that not a few citizens of Pennsylvania were prospecting daily on the lands beyond the river with a view to staking out claims and settling there. We have one instance of this in the effort of Henry Hendricks and Thomas Linvil mentioned above. ${ }^{1}$ Such settlements were, however, prevented for the time being. But when the opposition of the Indians subsided and when Hendricks had made a beginning, a veritable tide of immigration began to rise and sweep into the new territory. Many of these settlers took the trouble to secure the permission of the proprietary representative. Others settled irregularly though not without the knowledge and tacit consent of the government. It is known, for example, that Caspar Spangler settled in the valley in I 729 and that Tobias Frey had settled there prior to I $733 .^{2}$ Already in November, I729, Blunston could write to Logan: "Many people out of this province are for removing over the River so that I doubt not but another year will settle most of the habitable land for they flock over daily in search. The remainder of that by Hendricks would have been settled before now had they not been prevented."3

These settlers all took up their claims in the valley of the Kreutz Creek stretching westward and southwestward from John Hendricks's property. Hendricks's plantation was the oldest and therefore the best known of the plantations in that neighborhood and so was used to designate the location of other places. A number of these settlers afterwards in their depositions in referring to the location of their plantations would regularly affirm that they were

\footnotetext{
1 Vide supra, p. 25.

2 "The Spengler Families With Local Historical Sketches," pp. I7 and I38.
}

3 Vide Appendix $A$. 
situated a certain number of miles westward or southwestward from John Hendricks. ${ }^{4}$ The nationality of these earliest settlers in the community of the Kreutz Creek was almost without exception German. This fact is important for the subsequent history of the county and for a while it entailed rather serious consequences upon the settlers themselves. Carter and Glossbrenner remark: "The earliest settlers were English; these were however succeeded by vast numbers of German immigrants. . . . Most of the German immigrants settled in the neighborhood of Kreutz Creek. ... In the whole of what was called the 'Kreutz Creek Settlement' (if we except Wrightsville) there was but one English family, that of William Morgan." We have it upon the same good authority that the first tailor in the county was Valentine Heyer, that the first blacksmith was Peter Gardner, that the first shoemaker was Samuel Landis, who had his shop somewhere on the Kreutz Creek, that the first stone dwellings were built in 1735 on the Kreutz Creek by John and Martin Schultz. The first schoolmaster was known by no other name than "Der Dicke Schulmeister." Thus all the known arts of that primitive civilization among the county's first inhabitants were in the hands of Germans. The number and names of these earliest German settlers in the Kreutz Creek settlement, their legal status and their distressing experiences in their new homes we shall be able to understand after we have taken a glance at a parallel effort at settlement that was being made by Marylanders.

This Maryland settlement within the present limits of York County centered about the spot from which Parnell and others had been compelled to remove in 1728 . The

4 For example, Pennsylvania Archives, I: 523, 524; Col. Rec., III: 6r3. 
settling of the Marylanders here began in the year 1729 and grew rapidly during the next few years. Already on November 30, I729, Blunston wrote to Logan "All the land about Parnels ${ }^{5}$ is surveyed and settled by Marylanders." Afterwards when the dispute concerning the boundary had become acute the Marylanders sought to establish their claim to the region by proving their priority in time of settlement. For in I736 after the undignified controversy between the provinces had led to forceful conflicts and among other acts of violence the house of Col. Thomas Cressap, a Marylander settled at the mouth of Cabin Branch on the west bank of the Susquehanna, had been burned over his head, evidence was adduced to show that a number of persons living in the immediate neighborhood of Cressap's house had held lands under Maryland warrants for several years. Thus the evidence of Stephen Onion, taken at Annapolis on January I 2, I736, and preserved in the unpublished Calvert Papers, ${ }^{6}$ indicates that in 1729 Onion had secured a warrant from the Maryland office for "Pleasant Garden" which he sold to Thomas Cressap who settled and built "soon after it was surveyed"; that by virtue of a warrant from the Maryland office in the same year Jacob Herrington surveyed and "soon thereafter settled" a tract of 8 I acres called "Bulford"; that in 1730 by the same authority Thomas Bond secured a tract of 460 acres called "Bond's Mannour" and settled thereon William Cannon and John Lowe; that by virtue of warrant dated December 19, I729, Onion had surveyed on June 2, I730, a tract of 600 acres called "Conhodah" and had occupied the same in February,

5 Parnell evidently had been located there long enough to give his name to the place.

6 No. 3 I9. 
1732 ; that in 173 I Onion had secured a tract of 290 acres called "Smith's Choice" which was occupied by William Smith. "And this deponent also saith that before the improvements made on the said lands by the said settlers there were no improvements on them that this deponent saw but a few Indian Cabbins and a little hutt made of logs and a small quantity of ground cleared by a White Man who was driven away by the Indians as this deponent was informed and which hutt was sometimes empty and at other times possessed by the Indians and that no white person or persons was or were settled on any of the lands to this deponent's knowledge or that he hath heard of when the people herein beforementioned settled and improved the same, and further this deponent saith not."

Now Cressap's log house is known to have stood upon the spot cleared and improved by Edward Parnell and others and relinquished by them on order of the Pennsylvania government in 1728 . It was therefore about three and one half miles south of the property of John and James Hendricks. ${ }^{7}$ The other tracts referred to in Onion's deposition adjoined the Cressap property. For on March 1, 1736, Rachael Evans testified that her husband Edward Evans lived "about one and one half miles from Cressap's late dwelling house"; that Jacob Herrington lived one and one fourth miles westward from Cressap; that William Smith lived two miles westward from Cressap; and that Robert Cannon lived one and one half miles north from Cressap. Adjoining Cannon was John Lowe less than a mile westward from Cressap's house. ${ }^{8}$ No dates are given

7 The foundations and cellar of the house are still to be seen on the Maish property in Lower Windsor Township. A photograph of these remains in the possession of the York County Historical Society.

8 No. 319. 
for the actual settlement of these persons except in the case of Stephen Onion himself, and this date (February, I732) in all probability refers not to his first occupation but to a later location. But from other sources it would appear that Thomas Cressap was the first settler there. For on September I3, I73 I, Governor Gordon of Pennsylvania complained to Governor Calvert of Maryland because for several months he had heard rumors about grants from the Maryland Office for lands on the west side of the Susquehanna. Two weeks later the Indian Captain Civility complained to Samuel Blunston of Lancaster County because Cressap had settled at Conejohela and had been disturbing the peace of the Indians there. And the following January Cressap himself declared under oath that he had been living on the west side of the Susquehanna since March 16, I731.9 Stephen Onion seems therefore to have been the first Marylander to take out a warrant for land in that neighborhood and Thomas Cressap seems to have been the first settler. But as Onion's warrant was not secured until I729 and as Cressap did not settle there until I $73 \mathrm{I}$ it is clear that the Maryland settlements could not have followed very closely upon that of John Hendricks and certainly the closing sentence in Onion's deposition is a mistake. Priority of authorized settlement in the Kreutz Creek Valley cannot be maintained for the Maryland settlers even if this had constituted a valid claim to the territory. But from the foregoing it is evident that the settlements under Maryland authority were early enough and numerous enough and far enough north to constitute a real source of apprehension to any others who might claim jurisdiction over those parts.

9 Archives, I: 2:91, 295, and 3 Ir. 
Now it was the bitter conflict between the English citizens of Maryland gathered about Thomas Cressap at the mouth of Cabin Branch and the German citizens of Pennsylvania whose plantations stretched westward and southwestward from John Hendricks along the Kreutz Creek Valley, that shaped events among the very earliest inhabitants of our county and occupied the attention of both the settlers and the provincial authorities for several years. And it is from the documents pertaining to this conflict that we draw much of our information concerning those earliest settlers. ${ }^{10}$

10 This conflict was one of the incidents in the general contention between the two provinces concerning the boundary. William Penn received his title to Pennsylvania from the British Crown in 1681, and for more than eighty years thereafter the boundary lines between his province and Maryland were the source of almost constant dispute. There is now a bulky literature pertaining to this controversy and its tedious negotiations. Many of the documents bearing on the dispute are found scattered over the Archives and Colonial Records of the two provinces, and many of them remain unpublished among the "Penn Papers" in the Historical Society of Pennsylvania at Philadelphia, in the Department of Internal Affairs and the Division of Public Records at Harrisburg, and in the Maryland Historical Society at Baltimore (vide, e. g., Pennsylvania Archives, Second Series, Vol. VII, pp. 30I-400; for other literary references see Winsor's "Narrative and Critical History of America," Vol. III, p. 5If). A brief statement of the issues involved and the facts of the negotiations is found in the article by J. Dunlop, "The Controversy between William Penn and Lord Baltimore," in the "Memoirs of the Historical Society of Pennsylvania," Vol. I, pp. 1613-204. A popular statement of the case in brief compass is Chapter XI of Sydney George Fisher's "The Making of Pennsylvania."

Suffice it to say here that the whole difficulty concerning the southern boundary of Pennsylvania grew out of ignorance on the part of the proprietors in England as to the location of the 4oth degree of latitude in America. Lord Baltimore's grant (1632) was merely for the unoccupied part of Virginia from the Potomac northward, a very indefinite description. But in Penn's grant of $\mathbf{r} 68 \mathrm{I}$ the province of Pennsylvania is described as bounded " on the south by a circle drawn at twelve miles distance from Newcastle, northward and westward unto the beginning of the 4oth degree of north lattude and thence by a straight line westward." Now the "begin- 
It follows from the conditions of haste and irregularity under which the first surveys west of the Susquehanna were made and from the circumstances of intercolonial strife

ning of the 4oth degree" from the equator is the 39 th parallel. But the 39 th parallel runs just north the present city of Washington. And the 4oth parallel runs somewhat north of Philadelphia. Neither of these parallels falls within 12 miles of Newcastle. Thus the boundary was uncertain and while the propietary negotiations dragged on in England a petty border warfare began in America. The disturbances began east of the Susquehanna where the Pennsylvanians contended for lands as far south as the mouth of the Octoraro Creek, about 5 miles south of the present border. In $\mathbf{1}_{723}$ both proprietors agreed to abstain from making further grants in the disputed territory for eighteen months or until satisfactory adjustment could be made. But years passed and no conclusion was reached. By 17132 the controversy was carried into the region west of the Susquehanna, and here the Marylanders laid claim to the lands at the mouth of Cabin Branch and in the Kreutz Creek Valley, nearly thirty miles farther north than any point claimed by them east of the river. Their object was to extend the Maryland domain west of the river as far north as the 4 oth parallel of latitude. This region west of the river and within the present limits of York County, was the chief scene of the border warfare and the disturbances here are known as "Cressap's War."

In 1732 the proprietors of the two provinces agreed to have the boundary line surveyed. This agreement placed the southern boundary of Pennsylvania on a parallel of latitude fifteen miles south of a parallel passing through the most southerly point in Philadelphia. But because of other stipulations in this agreement it proved distasteful to Lord Baltimore and under various pretexts he delayed its fulfillment and refused to let the survey be made. So the acrimonious correspondence between the provinces continued but without effect. In 1735 the Penns began a suit in equity against Baltimore to compel him to fulfil his contract. This was not ended until 1750 , when it was decided in favor of the Penns. Meanwhile repeated appeals came from America asking that a provisional line be run in order to allay the hostilities between the inhabitants of the provinces. This resulted in an order from the King establishing the "temporary line of 1739 " fifteen and one fourth miles south of Philadelphia on the east side of the Susquehanna and fourteen and three fourths miles south of Philadelphia on the west side of that river. The pending proceedings in chancery resulted in 1750 in a decree that the agreement of 1732 should be carried into specific execution. But forthwith a dispute arose as to the proper methods of mensuration. This was not settled until 1760 . In 173.6 
attending the first settlements there, that the legal status of the earliest settlers is not easy to determine. It probably was not in all cases clearly defined at the time. The Marylanders took out their claims and settled under ordinary warants from the Maryland Office. This gave them a certain advantage over those who came from Pennsylvania. For according to established custom and law in Pennsylvania no titles whatever could be granted to lands until they had been purchased from the Indians. The government of Pennsylvania did not begin to issue even temporary licenses until I733. John and James Hendricks had settled on Indian territory before that time but this was by special permission of the proprietary government and then only on condition that they first secure the consent of the Indians. Their formal license was not issued until March, I733, and even this was only a temporary license. But in Maryland no such custom obtained with reference to the lands of the Indians and the Maryland authorities did not hesitate to grant permits to settle on lands that had never been purchased from the natives.

The Maryland government did indeed early recognize such a purchase as desirable for the security of its people. For Philemon Lloyd, the proprietary agent at Annapolis, in a letter of October 8, I722, to the "Co-Partners" in London urges at great length a treaty with the Susquehanna Indians and then remarks,

I do assure you Gentlemen that something of this Nature is very necessary to be don; for now, that we are about Lycencing our

two expert surveyors, Charles Mason and Jeremiah Dixon, were sent to America to supervise the survey of the boundary. This survey, carrying out the agreement of 1732, was completed on December 26, 1767, and has given us the famous Mason and Dixon Line, celebrated now as the dividing line between the two sections of the country during the Civil War. 
46 German Element in York County, Pa.

People, to make Remote Settlements, we must likewise use the Proper Measures to protect them; for the Lands next above our Settlements upon the west side of the Susquehannah, and all along upon the West side of Baltimore County, are cutt off \& separated from the Present Inhabited Parts by large Barrens, many Miles over; so that as yet, the setlers there can expect very little Communication with us; yet if they should be Cutt off \& Murthered by the Indians we must insist upon Satisfaction for the security of our present Outer Inhabitants; which may involve us in a fatall War. But by this Means of Purchasing those Indian Rights, we may think ourselves pretty secure, as well from those Indians themselves as from any strange Indians that shall traverse those Woods. ${ }^{11}$

Nevertheless no such purchase was ever made by Maryland and hence the Marylanders who took up lands within the limits of our county must be regarded as squatters and not as authorized settlers. They had warrants, it is true, but the validity of these warrants was always denied by the Pennsylvania authorities who claimed that whole region under the terms of the royal grant to William Penn.

Not until January, I733, did the proprietary government of Pennsylvania begin to issue its first licenses to take up land west of the river. The settlements that had been made there by Pennsylvanians before 1733 had been permitted by the government authorities with the consent of the Indians but no titles had been given. It was hoped that the lands west of the Susquehanna would soon be purchased from the aborigines and thus the Indian policy of the Penns might be carried out. Thomas Penn (son of William Penn, Sr.) arrived in the province August, I 732, and John Penn (eldest son of William) came in October, I734. ${ }^{12}$ But the Indian purchase west of the river was

11 Calvert Papers, No. 2, p. 54.

12 John Penn returned to London the following year to care for the interests of Pennsylvania in the boundary dispute with Lord Baltimore. Thomas Penn remained in the province until r74r. 
not consummated until late in the year $173^{6}$. Meanwhile the incursions of the Marylanders which Governor Keith more than a decade before had made the excuse for his survey of the "Mine Tract," were becoming a real menace to the proprietary rights in that region. The settlers from Maryland and under Maryland authority were pushing farther and farther north and were growing constantly bolder and more annoying along the west bank of the Susquehanna. The provincial authorities of Pennsylvania became convinced that active measures must be taken to secure the rights of their province in that region.

The Maryland authorities had long before felt that special inducements ought to be offered to settlers in that region. Their custom did not prevent them from issuing full warants for settlements on Indian lands. But even this, they felt, was not enough and ten years before the government of Pennsylvania took any measures to settle the new territory the proprietary agent at Annapolis had urged the granting of easy conditions for payment of warrants in order to induce citizens of Maryland to settle in this district west of the Susquehanna. Thus Philemon Lloyd, in the letter quoted above, writes:

If this Place were well Seated, it would be a good Barrier unto the Province on that Side \& doubt not, but that it would in a few years, bring on the Planting of that other Vast Body of Rich Lands, that lyes something more to the Westward; \& would likewise secure our Country against the Claims of the Pensilvanians on the North side; for we are allready Seated to the Northward of that Line, which I lay down for the true Location of Pensilvania upon the Back of the I2 Mile Circle, as they have encroached upon us to the Southward of that Line about Octeraro, \& to the Eastward of it, which seems to be occationed by our own too great Supiness; \& makes me so desirous now, of Seating farther up the 
Susquehannah; \& if his Lordship should be pleased to grant 7 or Io years Time for the Payment of the Ffines for Lands in those remote parts; he will, I verily am perswaded have his back part of his Country Seated, by more than Io years the sooner, . . . . There are other Advantages, that will Acrrue from Setling the Remoter Parts of the Province, by Conditional Warrants as above proposed: the Scotts Irish, \& Palatines, after the news of so great Concessions, will I imagine fflock apace in, \& Even some from Pensilvania it Self;

But even without such special inducements as were here proposed, the Marylanders, as we have seen, were flocking to the west bank of the Susquehanna much to the annoyance of the provincial government and the Lancaster County authorities just east of the river and to the great unrest of the Pennsylvanians who had settled west of the river.

In order to counteract these annoying encroachments the proprietary agents of Pennsylvania began to adopt the policy of encouraging citizens of Pennsylvania to cross the Susquehanna and settle west of the river acknowledging the jurisdiction of Pennsylvania in that region. For this purpose in January, I733, they commissioned Samuel Blunston, who lived near the river, ${ }^{13}$ to issue temporary licenses to such persons as were willing to take up lands on the west side of the river and settle there. These licenses were afterwards confirmed by the proprietor on October $3^{\circ}, 1736$, as soon as the lands could be purchased from the Indians. The full text of one of these confirmed Blunston licenses was presented as evidence in the case of Nicholas Perie in 1748 . It is of special interest because it was doubtless the same form that was used by the proprietor

${ }^{13}$ At Wright's Ferry, where Columbia now stands. 
in confirming the licenses of all the early German settlers in the county.

Pennsylvnia ss:

Whereas, sundry Germans and others formerly seated themselves by our Leave on Lands Lying on the West side of Sasquehanna River within our County of Lancaster, \& within the bounds of a Tract of Land Survey'd the Nineteenth and Twentieth Days of June, Anno Domini, I722, containing about Seventy thousand Acres, commonly called the Manor of Springetsbury;

And Whereas A Confirmation to the Persons seated on the same for their several tracts has hitherto been delayed by reason of the Claim made to the said Lands by the Indians of the Five Nations, which Claim the said Indians have now effectually released to Us by their Deed bearing date the Eleventh Day of this Instant, October;

And Whereas Nicholas Perie, one of the Persons living within the said Manor, hath now applied for a Confirmation of Two Hundred Acres, part of the same where he is now Seated;

I do hereby Certify that I will cause a Patent to be drawn to the said Nicholas Perie for the said Two hundred Acres (if so much can be there had without prejudice to the other settlers) on the common Terms other Lands on the West side of Sasquehanna River are granted, so soon as the said quantity shall be Survey'd to him \& a return thereof made to me

October 30th, 1736.

Tho. Penn. ${ }^{14}$

The nature of these licenses reflects the primitive methods of granting lands. They were variously known by the government as "licenses," "grants," and "certificates."15 They were not real warrants but merely approved the making of a survey and promised to order a patent to be drawn at some indefinite future time. They thus secured the

14 Col. Rec., V: 2 rg f.

15 Vide Hamilton's Warrant for Resurvey, infra, p. $53 \mathrm{f}$. 
settler in his right to his settlement. The licenses had all the essential features of warrants with the single exception that they showed no previous payment of purchase money. In the litigations that arose long afterwards over these tracts the Blunston licenses were regarded by some as mere locations, by others as actual warrants. The distinction was made in the courts between "warrants on common terms" and "warrants to agree." The former were warrants issued for lands that were not reserved by the proprietor but were offered to the public at a fixed price. The latter were contracts for the possession of lands which had been surveyed from the common stock as manors, had thus been withdrawn from the public market, and so could be acquired only by special agreement. ${ }^{16}$ The Blunston licenses were issued for lands that were supposed to lie within the Springettsbury Manor ${ }^{17}$ and so could be acquired only by special contract or "warrants to agree." But as a matter of practice they were always issued on common terms. Note, for example, the closing sentence in the Hendricks warrant, "on the same Terms other Lands in the County of Lancaster shall be granted" 18 and the closing sentence in the Perie warrant, "on the common Terms other Lands on the West side of Sasquehanna River are granted."19 These Blunston licenses afterwards played a very conspicuous part in the judicial investigation into the validity of the claim to these manorial lands west of the river. ${ }^{20}$

${ }^{16}$ Decisions of the Supreme Court of U. S., Wheaton, Vol. IX, p. 35, Curtis edition.

17 They were afterwards by the resurvey of 1768 actually comprehended in that manor.

18 Vide supra, p. 28.

19 Vide supra, p. 49.

20 Dallas Reports, Circuit Court, Pennsylvania District, Vol. IV, pp. 373- 
Samuel Blunston kept a careful list of the persons to whom he issued permits to settle west of the river together with the approximate number of acres allowed to each one. This list he transmitted from time to time to the Land Office in Philadelphia. It was preserved in that office until I 762 but has since disappeared. ${ }^{21}$ There is, therefore, no way of ascertaining directly the names and exact locations of the earliest settlers in the county. For no surveys of their tracts were made at the time. Blunston had surveyed in person the tract upon which John and James Hendricks had settled. He had laid out a tract of I,200 acres and had assigned one half of it to Hendricks, "the uper side and best part." This was done by special order of the secretary of the province and the exact location of this tract is well known. But when he issued his conditional grants $\left(1733^{-1736)}\right.$ he did not undertake the work of making the surveys and the new territory was well dotted with settlers before any surveys were made. ${ }^{22}$ Thus on March I 8, $1735,{ }^{23}$ Blunston wrote to Thomas Penn:

380. "Blunston's Licenses have always been deemed valid: and many titles in Pennsylvania depend upon them. ..." Ibid., p. Irr. Wheaton's Reports, Vol. IX, pp. 34-73.

21 Vide Governor Hamilton's Warrant for Resurvey of Springettsbury Manor, infra, p. 53 f. Perhaps it was on the occasion of this resurvey that the list of permits disappeared.

22 For some years, in fact, it was the express policy of the Pennsylvania government to avoid making surveys in this region. For Governor Gordon wrote to Governor Ogle on July 26,1732 , and speaking of the agreement of $x_{723}$ he said that convention "notwithstanding the numerous Settlements made by those who forced themselves upon us from Ireland and Germany, has been so punctually observed by our office that there has not been one Survey made, as is affirmed to me by Order of that Office, within the Limits which it was conceived Maryland either could or would claim." Archives, I: 338 .

${ }^{23}$ The date of the letter is March 18, 1734, but this was under the old method of dating. Under the modern method this would be March 18, 
Though as much care as possible has been taken to prevent disputes yet many are like to arise which can never be well adjusted without surveying to each their several tracts. And as warrants are already lodged here for that purpose I make bold to propose that a surveyor of sense and honesty (if such can be had) might be sent up as soon as possible for that service, which if done with expedition I am certain would be greatly for your interest and the only sure means of a regular settlement for I do not think it proper at this critical juncture to leave the people room to quarrel among themselves. Beside in a country so scarce of water as that is if the people are alowed to be their own carvers a great part of the land will be rendred uninhabitable. This as well as the other should be timely prevented. The people are now settling building and improving daily. This is the season for surveying which cannot so well be done in any other season as the six or eight weeks coming. This I thought to mention though I know of no person in these parts to recommend yet doubtless such may soon be had. . . . I should be glad to know thy mind herein that I may be able to give the people an answer for they are generally desirous and expect it will be done.

It is not at all certain that such surveys were ever made. No drafts of these settlements are known to exist. There is no trace of the confirmed warrants in the Land Office at Harrisburg. The individual surveys had evidently not been made when the Blunston licenses were confirmed in I736, and the words of Governor Hamilton's warrant for the resurvey of Springettsbury Manor leave little doubt that at least so far as most of the tracts were concerned no such surveys had yet been made in $1762 .{ }^{24}$ We are left

r735. We shall hereafter give all dates as they would be under the modern method.

24 The original survey of Springettsbury Manor, made in $\mathbf{1 7 2 2}$, is still in existence. It either had been mislaid or else was being purposely suppressed at the time the resurvey was ordered in 1762 . It has recently been discovered by the Hon. Robert C. Bair, of York, and was published in the 
therefore to inference and incidental allusions for our information concerning the names, the nationality, and the location of the earliest settlers in the Kreutz Creek Valley.

But such sources of information are not entirely lacking. It is clear in the first place that the Kreutz Creek Valley was from the beginning regarded as settled predominantly and almost entirely by Germans. For example, in Governor Hamilton's warrant of May 21, I762, for the resurvey of Springettsbury Manor, it is set forth that the manor was originally surveyed for the use of the proprietor on the I 9 th and 20 th of June, I 722 , and that

sundry Germans and others afterwards seated themselves by our leave on divers parts of the said manor but by reason of some claim made to those Lands by the Indians of the Five Nations (which they afterwards released to us by their Deed of the IIth day of October, 1736 ) the confirmations of the parts so seated in the said manor were for some time delayed. And whereas, upon our obtaining the said Release from the said Indians we did give to each of the persons so as aforesaid settled on our said Manour License or Certificate bearing date respectively the 3oth day of October in the year last aforesaid, thereby promising that we would order a patent to be drawn to each of them for their respective Settle-

Pennsylvania Annual Report of the Secretary of Internal Affairs, 1905, Part I, Map $E$, where it is shown to differ widely from the relocation made under Hamilton's orders. But the words of Hamilton's warrant indicate clearly that surveys for the grants to individual settlers had not been made systematically and were really not in existence.

In the Proceedings of The Supreme Executive Council, January 25, 1787 (Col. Rec., XV: 153), there is a suggestion as to what became of such copies of patents for tracts within the Springettsbury Manor as were recorded in the secretary's office. The secretary was there instructed to deliver to the attorney of the Penns the copies of warrants which had been issued for such tracts, and the proceedings of the council on September 22, 1788, indicate that these instructions were carried out and that "several inclosures" had been thus delivered. 
ments and plantations in the said Manor as soon as surveyed making in the whole by Computation 12,000 Acres or thereabouts, as in and by a Record and particular list of such Licenses or Grants remaining in our Land Office more fully appear. And whereas the survey of our said Manor is by some accident lost or mislaid and is not now to be found but by the well known Settlements and Improvements made by the said Licenced Settlers therein and the many Surveys made round the above said Manor and other proofs and Circumstances it appears that the said Manor is bounded on the East by the River Susquehannah, on the West by a North and South Line West of the late Dwelling plantation of Christian Esther, otherwise called Oyster (to which said Christian one of the said Licences or Grants was given for his Plantation) Northward by a Line nearest East and West Distant about three Miles North of the present Great Road leading from Wright's Ferry through York Town by the said Christian Oysters plantation to Monocksay and Southward by a Line near East and West distant about three Miles of the Great Road aforesaid. And whereas divers of the said Tracts and Settlements within our Manor have been surveyed and confirmed by patents to the said Settlers thereof or their assigns and many of them that have been surveyed yet remain to be confirmed by patent and the Settlers or possessors thereof have applied for such Confirmation agreeable to our said Licences or Grants whose requests we are willing and desirous to comply with and we being also desirous that a compleat Draught or Map and return Survey of our said Manor shall be replaced and remain for their and our use in Your Office and also in our Secretary's Office. ...

The "well known settlements and improvements" of these "sundry Germans and others" were Hamilton's chief means of determining again the bounds of the manor, the original survey of which had been temporarily lost. The Blunston licenses confirmed by Thomas Penn in 1736 
totaled about $\mathrm{I} 2,000$ acres. ${ }^{25}$ The entire manor as relocated under Hamilton's orders embraced 64,520 acres. The Blunston licenses therefore covered about one fifth of the manor. In the subsequent litigation concerning these manorial lands the number of licenses confirmed by Thomas Penn is stated to be fifty-two. ${ }^{26}$ Now there is abundant evidence to show that with very few exceptions these fifty-two licensed settlers occupying one fifth of the entire fertile valley afterwards included in the Springettsbury Manor were Germans.

25 The usual grant to each settler in those days was 200 acres. The grant to John Hendricks was in this respect also an exception.

26 In February, 1824 , in the case of Kirk and others, Plaintiffs in Error, vs. Smith, ex. dem. Penn, Defendant in Error, tried before the Supreme Court of the United States, evidence was produced showing that the number of licensed settlers on Springettsbury Manor in 1736 was fifty-two. Chief Justice Marshall delivered the opinion of the Court on that occasion and said among other things:

"Now it appears from the statement of the testimony made in the charge of the court to the jury, which is the only regular information of the evidence given in the case, that an agreement was entered into, in 1736 , between the proprietary and a number of the inhabitants, by which he agreed to make them titles for certain specified quantities of land in their possession on the common terms. This agreement is stated to have been afterwards carried into execution. The contract, as stated, contains unequivocal proof of having been made under the idea that the survey of 1722 was valid, that it related to lands within the lines of that survey, and that the lands within its lines were considered a manor. That survey may not have been attended with those circumstances which would bring it within the saving act of $\mathbf{1 7 7 9}$, and certainly, in this cause, is not to be considered as a valid survey of a manor. It was nevertheless believed, in 1736 by the parties to this contract, to be a manor: and those proceedings which took place respecting lands within it, are consequently such as might take place respecting lands within a manor. We find sales of lands made to fiftytwo persons upon the common terms, and grants made to them according to contract. When the final survey was made, comprehending these lands as being part of the manor of Springettsbury, were they less a part of that manor because they were granted as a part of it before the survey was made?" Wheaton's Reports, Vol. IX, February Session. 
For it must be remembered that the purpose of the proprietary agents in encouraging settlements beyond the Susquehanna was to preempt that soil for those who acknowledged the claims of Pennsylvania as over against the claims of "the Maryland intruders." This was not an afterthought on the part of the Pennsylvania government, as was so often claimed by the Maryland authorities in the trying times that followed. Pennsylvania's claim to this soil was a consistent one. From the time of the arrest of Philip Syng on Keith's Tract in 1722 and the original survey of Springettsbury Manor in that same year, to the final adjustment of the difficulties almost half a century later, Pennsylvania never relinquished her claim upon this region and never consented to recognize the Susquehanna as the boundary between herself and Maryland. This claim was recognized by Parnell and his associates in 1728 and it was only with the advent of Col. Thomas Cressap that the claims of Pennsylvania in this region were aggressively denied and withstood. The property of these earliest settlers in our county, therefore, became at once the immediate bone of contention between the two colonial governments in their border difficulties. It is through the recorded transactions incident to these border difficulties that we learn how large a proportion of the earliest settlements in the county were made by Germans, and these records, replete in their references to the "unfortunate" Germans, also tell us something about their names, their position and their purposes.

Thus on December IO, I736, the deposition of Michael Tanner was taken by Magistrate Tobias Hendricks as evidence in the case of Thomas Cressap the instigator and leader of the Maryland intruders. This Tanner was the 
same young German who had settled west of the river in the company of Edward Parnell and several other Englishmen and upon the complaint of the Indians had been expelled in 1728 . From his deposition we learn that he had persisted in his effort to settle west of the river and on September I7, I734, had made an authorized settlement of 200 acres six miles southwest of John Hendricks. This time he was not accompanied by English companions for now it was chiefly the Germans who seem to have been attracted across the river. Tanner also declares that in I 734 and 1735 Cressap with pretended authority from Maryland had surveyed upwards of 40 tracts of land for the Germans living in those parts. ${ }^{27}$

27 Michael Tanner (afterwards Danner) was a native of Mannheim, Germany. On September $27, \mathbf{1 7 2 7}$, when he was thirty-one years of age, he and his wife arrived at the port of Philadelphia. He passed the winter among his countrymen in the western part of Lancaster County. The following spring he crossed the Susquehanna, selected a tract of land near the mouth of Cabin Branch, where Parnell, Summerford and Williams had taken up their abodes. But when he applied to the government for permission to settle there and make improvement, it was refused and in the fall of the year he was required to remove from the west bank. In 1734 he secured a Blunston license and effected a settlement in the Kreutz Creek Valley. Here he soon became involved in the Cressap disturbances. During these difficulties and for some years thereafter Tanner was the spokesman for his countrymen west of the river (for example, Col. Rec., IV: 75). He stoutly resisted the claims of the Marylanders, rejecting their promises and ignoring their threats. In 1736 he was surprised and captured by the Marylanders while he was helping to bury one of his neighbor's children and was carried off and imprisoned for a time at Annapolis. Michael Tanner was a leader of men. When a measure of peace was restored in York County he was one of its most prominent citizens. His name appears frequently in the records of the County, as witness to wills, appraiser of property, executor of estates, and viewer of roads. In 1749 he was one of the commissioners to lay off the County. His signature grows constantly more Anglicized with the years, indicating the influence of his contact with English-speaking officials.

In religious faith he was a Mennonite, as is evinced by the fact that 
From similar depositions we learn that Balzer Springler (otherwise Spangler) ${ }^{28}$ in the beginning of 1733 under a Pennsylvania grant had settled and improved a tract of land on Codorus Creek twelve miles west of John Hendricks, but that he had been ejected by Cressap to make room for another German, John Keller; that late in I 733

he "solemnly affirmed according to law" instead of taking oath. It was under his leadership that the Mennonites coming from Lancaster County began to settle the rich farming lands in the Conewago Valley near Digges' Choice in 1738. He was afterwards a close friend of the Scotchman Richard McAllister, and it was probably due to Tanner's influence that McAllisterstown received the name of Hanover. His son, Jacob Danner, was the first elder of the German Baptist Church of Codorus, ri miles southeast of York, organized in 1758, and became involved in the famous religious controversy with Jacob Lischy. Vide Archives, I: $524 \mathrm{f}$. Division Public Records, Harrisburg, Provincial Papers, Vol. VI: 4, 15, 23. York and Lancaster County Records, passim.

28 John Balthasar Spangler was the eleventh child of Hans Rudolph Spangler. Born November 29, 1706, at Weiler-Hilsbach in the Palatinate on the Rhine, and married in April, 1732, he migrated to America and arrived at the port of Philadelphia on October Ix, I732. The following spring he made his way westward across the Susquehanna armed with a Blunston license for a tract on the Codorus Creek but he was forcibly prevented by Cessap from executing this grant. He soon succeeded however in gaining permanent possession of another tract of 200 acres. This he purchased from his countryman Tobias Frey and it lay one mile east of the Codorus, just south of the Peachbottom Road (now Plank Road) where it crosses the Mill Creek, in what is now Spring Garden Township. He gradually added to his possessions until in 176,3 he owned 483 acres. Part of this land has been incorporated in the city of York. Balthasar Spangler had been preceded to America and to York County by his elder brother Caspar and he was accompanied to the New World by his brothers George and Henry. Balthasar was one of the patriarchs in the early history of the County. When the town of York was laid out in ryili he was one of the first persons to take up a lot and build a house. When the first County election was held in I749 Spangler's house was the voting-place. He afterwards kept a public inn there. He was one of the most prominent and influential members of the German Reformed Congregation. He died in I770 possessed of a large estate and survived by six sons and two daughters. "The Spengler Families With Local Historical Sketches," pp. r38 ff. 
Frederick Lather, a German, had taken up his abode near the Codorus Creek, though at the persuasion of Cressap under a Maryland grant; that in I735 Frederick Ebert, a German, apparently without any grant had settled and improved a tract of land near the Codorus only to be expelled the next year by one of Cressap's agents to make room for another German, Ffelty Shults; that Martin Schultz and his wife Catherine were settled in Hellam Township (now York County) prior to I 736 and suffered violence at the hands of the Marylanders. These facts $\angle$ tend to confirm the impression, reflected by other public instruments, that the first people to settle in any considerable numbers west of the Susquehanna were Germans.

In 1736 the "Chester County Plot" was discovered. This was a conspiracy on the part of the Maryland sympathizers living in Chester County, Pennsylvania, "for ousting by force of arms those German families settled on the west side of the Susquehanna within the unquestionable bounds of this province [i.e., Pennsylvania]." Among the court records at West Chester is a document which contains the names of many of the German settlers west of the river in 1736 . It is the record of a "billa vera" against Henry Munday and Charles Higginbotham, instigators of the "Chester County Plot," in which they are charged with having conspired on October 25, I736, against "the lands and tenements of the honorable proprietaries, county of Lancaster, on west side of Susquehanna within the province of Pennsylvania then in the quiet and peaceful possession of

Christian Crawl

Henry Libert

Jacob Huntsecker
Peter Steinman

Henry Pann

Henry Smith 
60 German Element in York County, Pa.

Methusalem Griffith

Michael Tanner

Henry Stands

Martin Shultz

Jacob Welshover

Paul Springler

Andreas Felixer

Ulrick Whistler

Nicholas Booker

Hans Steinman

Conrad Strickler

Caspar Springler

Michael Walt

Peter Kersher

Reynard Kummer

George Pans Pancker

Frederick Leader

Michael Miller

Martin Weigle

Hans Henry Place

Tobias Fry

Martin Fry
Jacob Landis

Henry Kendrick

Tobias Rudisill

Jacob Krebell

Michael Springle

Jacob Singler

Philip Ziegler

Caspas Krever

Derrick Pleager

George Swope

Michael Krenel

Thomas May

Nicholas Brin

Kilian Smith

Martin Bower

George Lauman

Martin Brunt

Michael Allen

Christian Enfers

and

Nicholas Cone"

These forty-eight names are all the names of Germans, except one, that of Methusalem Griffith.

This list indicates very clearly, therefore, that as soon as the valleys west of the Susquehanna were opened to the settlement of white people there was a rapid influx of Germans and that the population there was from the beginning preponderatingly German. It is practically certain also that most of the fifty-two licenses issued by Blunston from I 733 to 1736 and confirmed by Thomas Penn in October, I 736, were taken by Germans. But it must not 
be concluded that all of the Germans in the Kreutz Creek and Codorus Creek Valleys had taken out "Blunston licenses." Most of them undoubtedly had secured these conditional "warrants to agree" before making settlement west of the river. Some however were not impressed with the immediate necessity of securing such license. For the Pennsylvania government was disposed to encourage the migration of its citizens across the Susquehanna and the easiest terms possible were granted. No purchase money whatever was expected until the Indian claim had been satisfied and in many cases the purchase money was not paid for some years even after I736. Moreover, those who chose to settle west of the river as squatters were no longer sought out and expelled. The securing of a Blunston license, therefore, seemed a mere empty formality which might easily be postponed to some more convenient time, and after the migration had once begun many of the people in Lancaster County saw no impropriety in removing and settling west of the Susquehanna River without even consulting the authorities. And so, while most of the settlers in the Kreutz Creek settlement had taken the precaution to secure a formal license for their land, a considerable number had settled there without having secured any license whatever but intending to take out license under Pennsylvania as soon as they should be called upon to do so.

It is worthy of mention in this connection also that there were quite a number who secured Blunston licenses to settle west of the river, but who never availed themselves of their permission and never actually took up their abodes beyond the Susquehanna. For Blunston remarks in his letter to Thomas Penn, March I8, I735, "I had not 
timely notice of this opportunity or I should have sent a list of the persons licensed to settle over Susquehanah which amount to about I $30 .{ }_{29}$ Many of these did not use their licenses, at least for some years, either because they could not find such tracts as they deemed desirable or else because the growing hostilities of the Marylanders deterred them. Hence Thomas Penn found it necessary to confirm licenses to only fifty-two persons and about I 2,000 acres was sufficient to satisfy all their claims.

The above list of persons against whom Munday and Higginbotham aimed their plot, cannot, therefore, be regarded as an exhaustive list of the Germans living in that region. It can be supplemented from another source. For many of the settlers west of the river, both such as had secured Blunston licenses and such as had not, were for a time induced by the dire threats and the alluring promises of the Maryland agents to accept Maryland warrants and surveys and to acknowledge Maryland authority. They soon found however that they had been deceived, that the Maryland authorities discriminated against them because they were Germans, and that their possessions were uncertain under the Maryland proprietary. So they made haste to repudiate their allegiance to Maryland and to acknowledge again the jurisdiction of Pennsylvania in those parts. This action the government of Maryland regarded as "the revolt of the Germans" and it led to serious disturbances in their neighborhood including an invasion of a body of 300 armed men from Maryland and the Chester County plot to force the Germans out of their possessions. Their lands were surveyed to other persons. Their property was stolen, demolished, or burned. Their doors were broken down with axes in the

29 Appendix $A$. 
dead of winter. Their growing crops were destroyed. Their sons and fathers were captured and imprisoned. They were subjected to all sorts of indignities and in some cases were glad to escape with their lives to the east side of the river.

Under date of August I3, I736, a petition of the Germans was delivered to the provincial council at Philadelphia asking that their error in accepting warrants from the government of Maryland be imputed to want of better information, and praying to be received again under the protection of the government of Pennsylvania. The council unanimously declared in favor of receiving the Germans again and of encouraging them in their fidelity. The correspondence concerning this return of the Germans to their allegiance to Pennsylvania helps us to further fix the names and total number of German settlers within the bounds of York County up to the end of 1736 . For on August II, I736, just two days before the Germans petitioned the council at Philadelphia for reinstatement as citizens of Pennsylvania, they wrote a somewhat similar letter to the governor of Maryland apprising him of their intention to acknowledge the jurisdiction of Pennsylvania. This letter was suggested by Samuel Blunston but was not drawn up or signed in his presence. Afterwards in reporting in person to the council in Philadelphia Blunston said that he had learned since coming to Philadelphia that the letter "was signed by about sixty hands." The lieutenant governor of Maryland in writing about this letter shortly thereafter said it was "subscribed with the names of fifty or sixty persons." This document was published in the Maryland Archives. ${ }^{31}$ Only 22 of these

30 Col. Rec., IV : 57 .

31 Md. Archives, Vol, 28: 1oo f. Vide also Col. Rec. Pa., IV: 6r f. 
names of signers are preserved in the Archives. ${ }^{32}$ But in the unpublished Calvert Papers ${ }^{33}$ we have a copy of the original document and this includes also a copy of the signatures. The signatures in this copy number fifty-six and they are identical with the names of fifty-six persons whose arrest was ordered by the Maryland authorities by proclamation on October 21 , I736, "for contriving signing and publishing a seditious paper and writing against his Lordship and this government." 34 These fifty-six names therefore undoubtedly constitute the full list of the signers of the letter of August II, I736. This list includes nearly all of the names mentioned in the document pertaining to the Chester County Plot (which took place in the Fall of that same year) and in addition includes such German names as
George Scobell
Hance Stanner
Tobias Bright
Tobias Henricks
Leonard Immel
Balchar Sangar
Peter Gartner
Michael Reisher

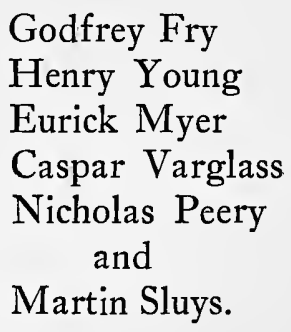

A few more names and locations of German settlers may be gathered from the depositions concerning the arrest of John Lochman, a German living west of the river. From the account of Lochman himself and from that of John Powell, undersheriff of Lancaster County, it appears

\footnotetext{
32 The original document went to England when the whole matter of the boundary dispute was to be reviewed in London, and there it was lost.

${ }^{33}$ No. 7 I7. For the list of signatures vide Appendix $B$.

34 The proclamation also includes in a separate list the names of four Lancaster County officials. These are English.
} 
that on December 24, I735, Robert Buchanan, sheriff of Lancaster County, and three others had arrested Lochman on a writ of debt at his house about seven miles west of John Hendricks's plantation and two miles south of the Little Codorus, within Ioo yards of the main road through the valley, and had taken him eastward past the home of his countryman Peter Gartner, "a Dutch Smith," when, about four miles west of Hendricks's, they were suddenly set upon by a number of Lochman's countrymen living in those parts. Lochman was rescued and the Lancaster County officers were sorely abused. Lochman asserts that there were "5 Dutchmen" in the attacking party and gives their names: Barnett Wyemour, Michl Risenar, Feltie Craw, Francis Clapsaddle, and Leonard Freerour. Powell asserts that there were about twenty or thirty in the crowd but names only six: Bernard Weyman, Michael Rysner, Christian Croll, Francis Clapsaddle, Nicholas Kuhns, and Martin Schultz. He says that these six together with Mark Evans "all live on the West side of Susquehannah River, not above one Mile to the Southward of the house of John Kendricks." This incident therefore gives us the location of Croll, Reisher, Cone and Schultz, and adds the names of Weimer, Clapsaddle, Feerour, Lochman, and Craw (or Kroh) ${ }^{35}$ to the above lists of names. ${ }^{36}$

The Maryland authorities estimated the number of

35 Croll's name was often spelled Crawl, especially by the Marylanders. But that this is not the same person as the Feltie Craw is evident not only from the difference in surnames but also from the Minutes of the Lancaster County Court for September 24, 1736, where it appears that both Ffelty Crow and Christian Croll were tried for disturbing the peace of Lancaster County and assaulting Sheriff Buchanan.

36 Proceedings of the Council of Maryland for 1735, p. 83. Col. Rec., Pa. III: $6 \mathrm{r} 2 \mathrm{f}$. 
Germans in that region at fifty or sixty families. For in a communication of Friday, February $\mathrm{I} 8, \mathrm{I} 737$ (i. e., the spring following the "revolt of the Germans"), from the Governor and Council of Maryland to the King they say ". . . accordingly not less than 50 or 60 families of that nation immediately took possession of those lands and paid their proportion of the taxes and demeaned themselves in every other respect as peaceable subjects of your Majesty and unquestionable inhabitants and tenants of this Province until very lately." 37

Now the petition of August 13, I736, in which the Germans pray the Council of Pennsylvania for reinstatement as subjects of that province, was signed by fortyeight Germans and was entitled "The Petition of Most of the Inhabitants on the West Side of the Susquehanah River opposite to Hempfield in the County of Lancaster." The list of subscribers to this petition ${ }^{38}$ must have been very much the same as the list of signers to the letter of two days previous, and as this number forty-eight embraces "most of the inhabitants west of the River" this document serves to corroborate the conclusion drawn from the Maryland letter and we have a fairly accurate idea of the number and the names of the Germans in this part of our county at the close of $1736 .^{39}$

37 Proceedings of the Council of Maryland for 1737 .

38 The list of signers was not preserved. The petition itself and the statement concerning the number of signers is given in the Colonial Records, IV: 64 f., and in Pennsylvania Archives, Second Series, Vol. VII: 202.

39 The difficulties grew worse during the winter of ${ }^{7} 736-1737$. This was the height of "Cressap's War." The "revolt of the Germans" was made the pretext for many cruelties that were perpetrated upon them. Some of the Germans who had assisted in rescuing John Lochman from the Lancaster County officials had been taken and lodged in the Lancaster County jail. John Hendricks was also imprisoned there for a time because he had harbored the Marylanders on his plantation which they used as a base of 
The improvements of these Germans lay in the fertile limestone valley of the Kreutz Creek stretching southwestward from John Hendricks's plantation, where Wrightsville now stands, to the place where the Kreutz Creek Valley merges into the Codorus Creek Valley, where the city of York now stands. This is the exact region that was included in the Springettsbury Manor when it was resurveyed in I768 under Governor Hamilton's warrant

operations against the Kreutz Creek Settlement. On the other hand, four Germans (Michael Tanner, Conrad Strickler, Henry Bacon, and Jacob Welshover) as they were in the act of burying a child, had been seized by the Marylanders and carried off to Annapolis. After a strenuous resistance, Cressap had been captured and was imprisoned in Philadelphia. But Higginbotham had succeeded to the leadership among the Marylanders at Cabin Branch, whom Samuel Blunston called "that nest of Vilains at Conejohala." Several lives had been lost in the conflicts. The Germans were being subjected to great inconveniences and serious dangers. Eighteen of their number had been seized and lodged in the Maryland jail (Maryland Archives for 1737, May 2.3). The others became terrified when their leaders had been captured and near the end of December, 1736, very many of them deserted their habitations and sought safety east of the river. Early in January, I737, Blunston wrote in a letter to the Council at Philadelphia: "They have left their homes and are come over the River so that there are none left on that side but women and children. . . B Before this happened if the sheriff had gone over he might have had 30 or 40 Dutch to assist him, but now he has none but what he takes with him if he can go over." Archives, I: ${ }_{3}$ I 7 (for the date of the letter vide Col. Rec., IV: 149). This evidently refers to the number of those who lived nearest to the river and who could have been counted on to assist against the Marylanders. Measures were taken to protect them and in a few days they all returned again to their homes and families. On May 23, 1737, Joseph Perry and Charles Higginbotham reported to the Maryland Council that they have " apprehended several Dutchmen and others set forth in proclamation as disturbers of the peace." The twenty-two names which they recite as partial list of those captured include the names of Tanner, Strickler, Bacon, Welshover, Liphart, and others prominent in the history of the Kreutz Creek Settlement (vide Md. Archives for 1737). But by this time the negotiations between the two provinces had advanced so far in the direction of peace that the captives were not long detained in Annapolis. 
of $\mathrm{r} 762$. It has been asserted that the original survey of the Springettsbury Manor was purposely suppressed at the time of the resurvey because the provincial authorities wanted to exchange bad land for good. ${ }^{40}$ However that may be, it is certain that the resurvey, differing widely from the original, was made to embrace part of the most fertile area in the county. It comprehended a tract six miles wide extending from Wright's Ferry along the entire length of the Kreutz Creek Valley to the plantation of Christian Eyster one and a quarter miles west of the town of York. The resurvey thus included nearly all of the plantations of the Germans, if not all, and it thus bears eloquent witness to the superior skill of the Germans in the selection of good soil for their locations.

${ }^{40}$ Dallas Reports, IV : 379. "It is further argued, that the recital of the loss of the survey of $\mathbf{1 7 2 2}$, is a mere pretence, a fraud, to enable the proprietaries to exchange bad land for good."

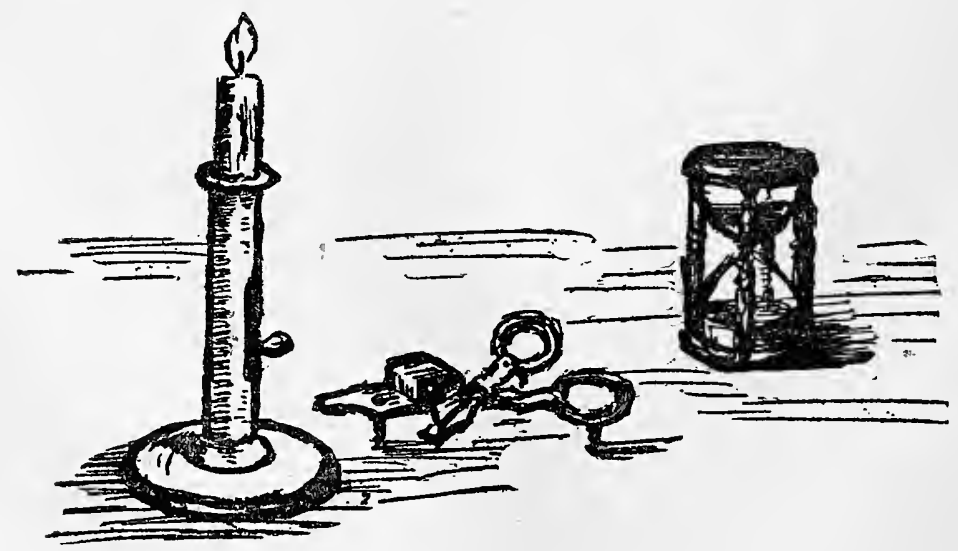




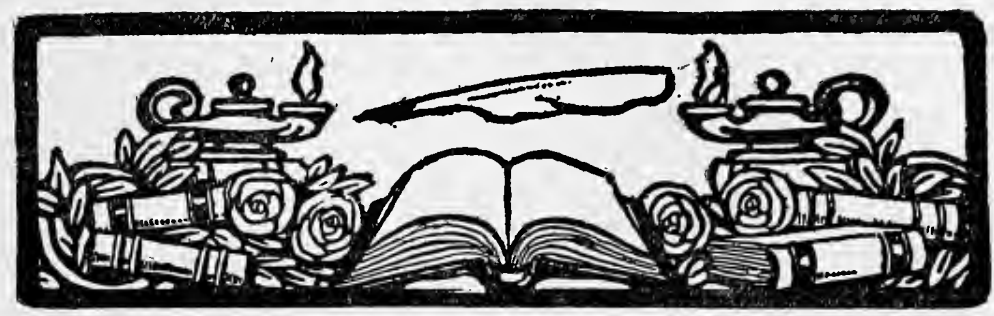

\section{CHAPTER IV.}

\section{Other EARly Settlements.}

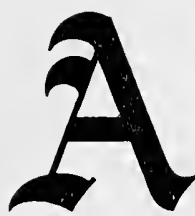

NOTHER German settlement, among the earliest of all settlements within the present limits of the county, was that made where the city of Hanover is now situated. In the time of its beginnings it followed very closely upon the commencement of the Kreutz Creek Settlement, but in its earlier years it did not grow nearly so rapidly as its sister settlement in the eastern part of the county. The history of this settlement furnishes striking instances of the hardships which the German pioneers in our county were obliged to undergo.

This second German settlement was made under a Maryland grant and was therefore the occasion of no little strife between the agents of Maryland and those of Pennsylvania. The original settlement was known as "Digges' Choice," from the owner of the tract upon which the settlement grew up. John Digges was a petty Irish nobleman of Prince George County, Maryland. On October I4, I727, he obtained from Lord Baltimore a warrant

1 In Maryland a custom obtained of naming the tracts for which warrants were granted. For a few instances of this vide supra, p. $40 \mathrm{f}$. These names usually expressed either some quality or circumstance of the tract or some fancy of the warrantee or some aspect of public opinion concerning the venture. 
for 10,000 acres of land. The warrant empowered him to locate the grant "on whatsoever unimproved lands he pleased within the jurisdiction of his lordship." No survey was made for four and a half years but the warrant was kept in force by repeated renewals. Meanwhile under the direction of the noted Indian chief, Tom, Digges had selected for his grant a promising tract of land embracing the whole of Penn Township, in which Hanover is now situated, and most of Heidelberg Township but extending also into what is now Adams County and including parts of Conewago, Germany and Union Townships. The survey was made in April, I732, and embraced 6,822 acres, although the patent was not issued until October I I, I735. The full title of the tract in the return of the survey was "Digges Choice in the Back Woods." Unfortunately for those who afterwards settled in those parts, this tract had 270 courses and these were not marked except on paper, only the beginning boundaries being marked on the tract itself. ${ }^{2}$

Digges's Choice soon began to be settled, and that too by

2 Only about 120 of these courses were indicated on the return of the survey made by the surveyor, Edward Stevenson. About $\mathbf{r}_{50}$ of the courses run on the land were left out of the draft in order to produce a more regular figure. It was this action on the part of the surveyor that led to much of the confusion among the settlers afterwards. This confusion would have been impossible under the Pennsylvania system of making surveys. For under that system trees were marked on the ground and where there were no natural boundaries artificial marks were set up to distinguish the survey. Stevenson's field notes of the original Digges's survey contained 270 courses and embraced the full grant of ro,ooo acres. But the return of the survey did not follow these field notes and there was nothing on the tract itself to indicate the courses. These facts were brought out in the judicial determination of the matter in the case of Thomas Lilly's lessee $v$ s. George Kitzmiller, tried before Justices Shippen and Yeates at York in May, 179r. Vide Yeates, "Reports of Cases in the Supreme Court of Pennsylvania," I: 28-33. 
Germans. Of the many squatters who had begun to cross the Susquehanna about I 730 and locate here and there on the lands of the peaceful Indians, some were attracted to the Digges estate. The Pennsylvania authorities could grant no kind of license before 1733 and then only provisional licenses, whereas on the Digges lands, held under a Maryland grant, full and permanent licenses could be obtained at once. For the charter of the Maryland proprietor, as we have seen, permitted him to authorize settlements in western Maryland irrespective of the Pennsylvania purchase of the Indian title. This fact undoubtedly operated as a special inducement to attract settlers to Digges's Choice. Then, too, Digges took active measures to sell his lands and to start a settlement on his tract. Both in person and through his agents he crossed to the east side of the Susquehanna River where he advertised his acres among the citizens of Pennsylvania and sought to make sales of plantations under his Maryland patent west of the river. This he did even before the survey of his "Choice" was made, and this entire agitation among Pennsylvanians was deeply resented by the Pennsylvania authorities. Thus a letter from John Wright to James Logan, April Io, I 73 I, ${ }^{3}$ tells that the writer had "learned that Thomas Digges had come over the River and gone amongst the Duch to sell lands," 4 that Digges had taken up 20,000 acres of which " 8000 lye between Conewago and Codorus Creeks," and that Wright had "openly resisted" Digges in his effort to induce Pennsylvanians to remove to Mary-

${ }^{3}$ Among the "Official Penn Manuscripts" in the Historical Society of Pennsylvania at Philadelphia.

4 Wright was in error as to the surname, and indeed, the entire letter shows that Wright's information on the subject was inaccurate, though there can be no doubt about the main fact of Digges's propaganda west of the river before April 10, I73I. 
land. Nevertheless Digges's efforts west of the river were not without avail.

The earliest purchase of lands on Digges's Choice and within the present limits of York County ${ }^{5}$-the earliest of which we have any record-was made by Adam Forney on October 5, I73I. As Digges could not at that time give absolute title to the land, no survey having been made and no patent having been issued, he gave Forney his bond for 60 pounds to deliver the title at some future time. ${ }^{6}$ Forney's purchase was for I 50 acres. It covered what is today the heart of the city of Hanover. This was near the "Conewago Settlement" which was also on Digges's Choice, but in what is now Adams County, and which had

5 Other purchases had been made from Digges's tract about a year before this, but they fall within the present County of Adams and they were not made by Germans.

${ }^{6}$ This bond is typical of a number that Digges issued to the earliest Germans who bought lands and made settlement upon this tract: "Know all men by these presents, that I, John Digges, of Prince George's County, in the Province of Maryland, Gent, am held and firmly bound unto Adam Faurney, of Philadelphia County, in the Province of Pennsylvania, Farmer and Taylor, in the full and just sum of Sixty pounds current money of Maryland, to which payment well and truly to be made and done, I bind myself, my Heirs, Executors and Administrators, firmly by these presents. Sealed with my seal and dated this fifth day of October, Anno Domini, r73 I.

"The Condition of the above obligation is such that if the above bound John Digges, his Heirs, Executors or Administrators, shall and will at the reasonable request of the above Adam Faurney, make \& order by sufficient conveyance according to the custom and common usage of the Province of Maryland, a certain parcell of land containing one hundred and fifty acres already marked out by the above named Adam Faurney, near a place known by the name of Robert Owing's Spring, and on the same tract of land where the said Robert Owing now Dwells in the Province of Maryland, then this obligation to be void, otherwise to remain in full force and virtue of Law.

"Sealed and delivered in the Presence of us, George Douglass,

“JoHN Digges."

Johann Peter Zarich.” 
been begun in 1730 by Robert Owings and other Catholics from Maryland. ${ }^{7}$

Adam Forney came to York County from Philadelphia County. He was originally a tailor in Wachenheim-inthe-Haardt in the Palatinate, whither his ancestors had probably come as Hugenot refugees from religious persecution in France. With his wife, Elizabeth Lowisa, and four children he arrived at the port of Philadelphia on October $16,1721 .^{8}$ For a decade he remained in Philadelphia County. By the city magistrates in Germany he was styled "citizen and tailor." In Digges's bond he is

7 Vide John T. Reily's "Conewago: a Collection of Local Catholic History," pp. $39 \mathrm{ff}$.

8 The ancestral family Bible of the Forneys at Hanover records this fact. Forney's name in Germany was Johann Adam Faurney, but, like a great many other Germans with Johann or Hans as an initial surname, Forney dropped the Johann shortly after coming to this country.

9 The certificate of dismissal which he received upon his departure from Wachenheim is still in the possession of his descendants in Hanover. It furnishes evidence of his favorable standing among his fellow-citizens in Germany. The English translation published in "The Forney Family, I690-1893" (pages 2 and 3 ) is as follows:

"We, magistrates, burgomasters and council of the city of Wachenheimin-the-Haardt, certify herewith that before us came the worthy Johann Adam Forney, citizen and tailor here, the legitimate son of the worthy Christian Forney, also a citizen here, and informed us that he, with his wedded wife, Elisabetha Lowisa, have firmly resolved to set out with their four children and effects, on the journey to the island of Pennsylvania and to settle there; but he stands in need of an attested certificate of how he behaved with us and why he departed, such as he can show at the place of his settlement. Which we gave him according to his reasonable desire and truthfully; moreover because we believe it would really be required in order that no one may calumniate our citizen or citizen's children; although we have indeed sought dilgently and earnestly to dissuade him from such departure, yet he remains of his first intention; therefore after steadfast perseverance we have given the said Johann Adam Forney this certificate: That as long as we have known him he has behaved himself honorably, piously and honestly, as well becomes a citizen and artisan, and moreover, 
described as "farmer and tailor." In York County he became farmer and inn-keeper. ${ }^{10}$ Forney made his purchase in $\mathrm{I} 73 \mathrm{I}$ but whether he settled at once upon the tract he bought cannot be ascertained as there is no record of his settlement. But when in I734 Andrew Schreiber settled on the Conewago his nearest neighbors, he tells us, were the family of Adam Forney, four miles distant. ${ }^{11}$ And as Forney marked off his purchase in person in the fall of $\mathrm{I} 73 \mathrm{I},{ }^{12}$ it is highly probable that he settled there immediately or very shortly after that. The new settlement may be said therefore to have actually begun a little more than three years after John Hendricks took up his abode on the west bank of the Susquehanna and almost simultaneously with the first influx of German immigrants into the Kreutz Creek Valley.

Another prominent individual among the first settlers in this new settlement was Andrew Schreiber, lineal ancestor of Admiral Winfield Scott Schley. Andrew Schreiber was born at Alstenborn in the Palatinate in I 7 I 2. His parents, Andrew and Ann Margaretha, together with their chil-

showed himself so neighborly that no one has had any complaint to make of him; he also is bound to no compulsory service or serfdom; he will not be unwilling to give, to show with all readiness to those of his intended residence all affection and kindness. To this true certificate we, the authorities, have affixed our city council's great seal to this statement which is given at Wachenheim-in-the-Haardt, the 7 th of May, 172r."

${ }^{10}$ The Moravians, Leonard Schnell and Robert Hussey in the diary of their missionary journey from Bethlehem, Pa., to their brethren in Georgia, November 6, 1743 to April ro, 1744, remark that after leaving York on November 15, "Towards evening we came to the district which is called after the river "Canawage." We lodged in an inn. The name of the inn-keeper is Adam Forny. He complained much about ministers and their useless efforts." Virginia Magazine of History and Biography, Vol. XI, $1903-4$, p. $37 \mathrm{r}$.

11 Vide "The Shriver Family, 168:4-r 888," Samuel S. Shriver, p. I4. 12 According to the text of Digges's bond quoted above, footnote 6 . 
dren, after "having borne many adversities,"13 emigrated to America arriving in Philadelphia late in the year I72I. The family first settled at Goshenhoppen, near the Trappe, on the Schuylkill River. Here Andrew the younger married Ann Maria Keiser in the spring of 1733 and in June of that year removed to York County. ${ }^{14}$ From John Digges he bought a tract of 100 acres near what is now Christ Church and paid for it with one hundred pairs of negro shoes, the price agreed upon. This location was four miles west of the plantation of Adam Forney. Here Schreiber lived on peaceful terms with the neighboring Indians and subsequently made additional purchases of land from Digges. He hunted deer and tilled the soil by day and tanned deerskins in the evenings. He became the progenitor of the numerous family of Shrivers who live in that community at present.

When Andrew Schreiber set out from Goshenhoppen for the region west of the Susquehanna in the summer of I 733 he was accompanied by his stepbrother David Jung (Young) who remained with him about three weeks, until they had cleared a few acres and planted corn on it, and then returned home. But shortly thereafter, probably the next year, Young also bought a tract from John Digges and took up his abode not far from his stepbrother Schreiber. ${ }^{15}$ Other neighbors from Philadelphia County soon

13 These words occur in the certificate of dismissal which Andrew Schreiber received from John Mueller, the Reformed pastor of Alstenborn. This certificate is still in the hands of the Shrivers and is reproduced in "The Shriver Family," p. ro.

14 A statement of the late Hon. Abraham Schriver, resident judge of the Frederick County court, is authority for the information concerning the original homestead on the Schuylkill and Andrew's marriage and removal to York County. Communicated to the "Star and Sentinel" for March 1876, by John A. Renshaw.

15 The fact may be gathered from the deposition of Robert Owings on 
followed these two pioneers, among them Ludwig Schreiber, brother of Andrew, Peter Mittelkauff, and Michael Will.

Among the other early settlers in this new community whose names have been preserved were many whose descendants are still to be found in the thriving town of Hanover and its prosperous vicinity. As early as I73I Nicholas Forney and Peter Zarich were there. In 1732 or 1733 we find that John Lemmon, Adam Miller, and Adam Messier have had surveys made to them on Digges's tract. In 1734 Conrad Eyler and his son Valentine had settled there, receiving their warrants in $\mathrm{I} 73^{8}$. In I 735 Henry Sell and the following year Martin Kitzmiller had joined the settlement. Before I737 Peter Jungblut (Youngblood), Matthias Marker, Jacob Banker, William Oler, Peter Oler, and Peter Welby had taken out grants. In 1737 at least two more additions were made, Derrick Jungblut and Peter Reisher (Rysher). In I738 George Evanaar received his warrant and by $\mathrm{I} 74 \mathrm{I}$ we meet with such names as those of Herman Updegraf, the shoemaker, Peter Schultz the blacksmith, Matthias Ulrich, and Peter Ensminger, and a few years later with Martin Brin, Abraham Sell, Martin Ungefare, and John Martin Inyfoss. ${ }^{16}$

July 18,1746 , and the approximate date of Young's settlement is also implied there. Archives, I: 695 .

16 These names and dates are gathered by inference from the Pennsylvania Archives and the Pennsylvania Colonial Records embodying the negotiations of the proprietaries concerning the boundaries of their respective provinces. The records of these negotiations are to be found chiefly in the Archives, I: $680-7^{\prime} 5^{\prime}$ and Colonial Records, V: $582-597$. The names that occur there cannot be regarded as at all exhaustive of the list of inhabitants in the entire settlement. They are chiefly such as happened to be located on that portion of the entire tract which was in dispute between the two provinces.

In the course of the correspondence between the two provinces in $\mathbf{7 7 5 2}$, 
But the lives of these enterprising and industrious Germans were no more peaceful than those of their countrymen who had settled about the same time or a few years earlier in the eastern part of the county. This was through no fault of their own. Their purposes were altogether peaceful and their motives beyond reproach. They had not even been made the victims of a scheme to preempt the soil for a particular province, as was the case with most of the early settlers in the Kreutz Creek Valley. They had ventured out upon those newlands in quest of quiet homes where they might worship without hindrance and might work undisturbed, sowing their crops and reaping the fruits of their own labors. But they had the misfortune to settle upon border land at a time when boundaries were indefinite and open to dispute. The consequence was, their days were fraught with distraction and their lives were in many cases made miserable for years. The blame for this condition of affairs must rest entirely with the authorities. The irregular and indefinite boundaries of Digges's reservation caused much uncertainty as to

President Tasker of Maryland transmitted to Governor Hamilton of Pennsylvania a copy of a warrant to collect taxes of persons settled on Digges's Choice under Maryland rights (Col. Rec., V: 592; Archives, II: 90 f.). Governor Hamilton recognized the jurisdiction of Maryland over the property of the persons mentioned in that warrant and gave strict orders to the officers in York County not to try to collect from them (Archives, II: 8ig f.). The warrant had been issued in January, 1750, and gives the names of 40 persons who were settled at that time north of the temporary line between the provinces but under Maryland jurisdiction. In addition to the names already mentioned we have in this list such German names as

$\begin{array}{lll}\text { Martin Bayers } & \text { George Shrier } & \text { Peter Gerson } \\ \text { Christian Stoner } & \text { Philip Kinsfoor } & \text { Henry Null, Dr. } \\ \text { Casper Berkhamer } & \text { Jacob Perts } & \text { Michael Behlar } \\ \text { Philip Sower } & \text { Andrew Hanier } & \text { Henry Knouf } \\ \text { John Counts } & \text { Conrad Eakron } & \text { John Shreder } \\ \text { Frederick Sheets } & \text { George Frusch } & \text { George Coffman }\end{array}$


the validity of their titles and led to frequent disputes between Digges and the settlers on his lands. The conflicting claims of the Penns and Lord Baltimore to the proprietorship in that region only served to aggravate the difficulties and involved the inhabitants in greater turmoil. The land upon which many of the Germans had settled came to be known as "the disputed land." Unlawful claims were made and violent measures were resorted to in enforcing them. Jurisdiction in criminal cases was diffcult to determine, the administration of justice was impeded or prevented, and lawlessness naturally flourished. For this reason the community was sometimes referred to as "Rogues' Resort," but this cannot be taken as a reflection upon the character of the earliest settlers and the permanent residents in that district, for it was due to conditions brought about entirely by the neglect of the distant authorities in Philadelphia, in Baltimore, and in London. A brief narrative of some of the disturbances in this region will help us to understand something of the adverse conditions under which this settlement took its beginnings.

Some of these Germans who were settled on and about the Conewago Creek on the lands claimed by John Digges soon began to suspect that his patent did not cover all that he claimed, that he was not in a position to give valid titles, and that some day the proprietary government of Pennsylvania might compel them to pay a second time for the lands which they occupied. Digges's boundaries were not marked and the increase of settlers and the expanding of the colony called for a clear definition of rights. The Germans therefore repeatedly called on Digges to mark the boundaries of his claim. This he refused to do, and as he gave conflicting accounts of the extent of his patent, they began to grow solicitous about the validity of their deeds. 
Their suspicions were turned to certainty when in 1743 they sent one of their number, Martin Ungefare, to Annapolis and secured an attested copy of the courses of Digges's tract. Despite Digges's protests and threats of violence the Germans proceeded to have the courses of his tract run by an authorized surveyor, and then it was plain that he had claimed a great deal more land than he had a right to by his patent and that he had sold a number of tracts that lay without his survey of 6,822 acres.

Digges was greatly disturbed by this revelation and began at once to cast about for some means of securing title to such lands as he needed to fulfill his contracts with the people. To secure an additional patent under a new survey from Maryland was now impossible. For a royal order of $1738^{17}$ had fixed a temporary line (called the

17 This was an order issued by the King on May 25, 1738, ratifying an agreement between Lord Baltimore and the Penns. In this Order the following paragraphs are of interest in this connection:

3rd, "That all other lands in contest between the said proprietors now possessed by or under either of them shall remain in the possession as they now are (although beyond the temporary limits hereafter mentioned) ; and also the jurisdiction of the respective proprietors shall be finally settled; and that the tenants of either side shall not attorn to the other, nor shall either of the proprietors or their officers receive or accept of attornments form the tenants of the other proprietors.

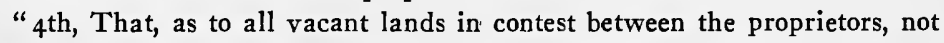
lying within the three lower counties and not now possessed by or under either of them, on the east side of the River Sasquehannah down so far south as fourteen miles and three quarters of a mile south of the latitude of the most southern part of the city of Philadelphia, the temporary jurisdiction over the same is agreed to be exercised by the proprietors of Pennsylvania, and their governor, courts, and officers; and as to all such vacant lands in contest between the proprietors and not now possessed by or under either of them on both sides of the said River Sasquehannah south of the southern limits in this paragraph before mentioned, the temporary jurisdiction over the same is agreed to be exercised by the proprietor of Maryland and his governor, courts, and officers, without prejudice to either proprietor and until the bounds shall be finally settled." Archives, I: 7r3 $\mathrm{f}$. 
Temporary Line of 1739) between the two provinces west of the Susquehanna at fourteen and three fourths miles south of Philadelphia but provided that lands already possessed in the disputed territory should remain in the possession and jurisdiction in which they then were. Now Digges's Choice lay four miles north of the temporary line, and while under the provisions of the royal order it remained in Digges's possession and continued under Maryland jurisdiction, nevertheless after 1739 the province of Maryland could claim no kind of authority over any of the lands surrounding Digges's Choice north of the temporary line between the provinces. Accordingly in November, I743, after the Germans had deliberately surveyed the boundaries of his claim and thus had laid bare his false pretensions, Digges applied to the land office of Pennsylvania for permission to take up enough land to make his tract a regular square. He was told that he might have a warrant for as much as he pleased, provided he would meet the common terms of Pennsylvania and would not interfere with the rights of some Germans who had regular warrants for some of the lands contiguous to his tract. These conditions he refused to meet and he left Philadelphia without coming to any agreement with the secretary.

Digges then resorted to a new measure. He turned to Maryland and determined to get a Maryland warrant to complete his original grant of I0,000 acres. In July, I745, a warrant was issued from the office at Annapolis requiring the surveyor to correct the errors of the original survey and to add any vacant land he could find contiguous to the tract originally patented. This survey was made two weeks later and embraced an additional 3,679 acres. For this Digges paid a new consideration and a new rent. 
The patent therefore was in direct violation of the royal order of 1738 and of the rights of Pennsylvania in that region. Digges claimed that he had merely made a resurvey marking the true courses of the I0,000 acres that had been granted to him originally. Nevertheless, his new patent embraced several German plantations that had not been embraced in the original survey and included a number of tracts for which warrants had been granted to German settlers by the proprietaries of Pennsylvania. ${ }^{18}$ All of these lands Digges offered for sale and thus we have the fruitful cause of years of conflict and turmoil in this neighborhood.

There were at least fourteen Germans who had settled under Pennsylvania warrants outside of Digges's original

${ }^{18} \mathrm{An}$ instance of such a granit is to be found in the following document now in the possession of the York County Historical Society. It is a land warrant granted to George Evanaar, a German, and signed by Thomas Penn, on October $5, \mathbf{1 7 3} 8$, a year before the temporary line was run between Pennsylvania and Maryland.

"Whereas George Evanaar, of the County of Lancaster, hath requested that we would grant him to take up one hundred acres of land situated at Conewago, adjoining Adam Forney and Nicholas Forney, in the said County of Lancaster, for which he agrees to pay to our use the sum of fifteen pounds, ten shillings current money of this province for the said one hundred acres, and the yearly quit-rent of one half penny sterling for every acre thereof. This is therefore to authorize and require you to survey or cause to be surveyed to the said George Evanaar at the place aforesaid, according to the methods of townships appointed, the said quantity of one hundred acres, if not already surveyed or appropriated, and make return thereof into the secretary's office, in order for further confirmation; for which this shall be your sufficient warrant; which survey in case the said George Evanaar fulfill the above agreement within six months from the date hereof shall be valid otherwise void. Given under my hand and seal of the land office, by virtue of certain powers from the said proprietaries, at Philadelphia, this fifth day of October, Anno Domini, One Thousand Seven Hundred and Thirty-Eight.

"To Benjamin Eastburn, Surveyor-General.

Thomas Penn." 
survey of 1732 but within his resurvey of I745. In April, I746, these Germans sent a delegation to Philadelphia with a petition to the Pennsylvania authorities asking for protection in their rights as against Digges's aggressions. ${ }^{19}$ Thomas Cookson, surveyor of Lancaster County, was sent to the Conewago to warn Digges and the people against violations of the royal order. ${ }^{20}$ But to no avail. Digges insisted that his resurvey and new warrant were merely confirmatory of the originals and therefore no violations of the royal order. The governors of the two provinces began a correspondence about the matter but without definite results for many years. Meanwhile the settlers in the disputed land were kept in constant uneasiness, a number of arrests were made and violent conflicts took place, thus greatly retarding the growth of the settlement.

Very shortly after Cookson's visit to Digges's Choice in April, 1746, Thomas Norris, deputy sheriff of Baltimore County, at the suit of John Digges arrested Matthias Ulrich and Nicholas Forney (son of Adam Forney), two of the German settlers on the disputed land. This was done because these men failed to give Digges their bonds for the lands which they held. The sheriff took his prisoners as far as Adam Forney's house. Here Adam Forney remonstrated with the sheriff, insisting that the prisoners were settled under proper Pennsylvania warrants and offering to go bail for them. This was refused, whereupon Forney boldly told the two men to return to their homes. The sheriff drew his sword and Forney's party drew theirs, but without coming to blows the sheriff and his assistants, Dudley Digges and John Roberts, mounted their horses and fled towards Maryland. Then Forney wrote an ac-

19 Archives, II: 28 .

20 Archives, I: 68I-683. 
count of the affair to Cookson, pleading for his intervention and assistance and concluding: "For if this matter is not rectified, \& we do not get help speedily, we must help ourselves, \& should it be with our last Drop of Blood, for I am well assured that we will not be put upon by no Digges that ever lived under the sun. . . . Digges also troubled many more, in short all them that lives in his resurvey'd Additional Line, \& was a going to have them arrested, but some sent them a packing in the Striving. . . ."21

The troubles grew worse and Digges discovered that the Germans were as stubborn in maintaining their rights as he was determined to force them into submission. On January 26, I747, John Wilmot, an under-sheriff of Maryland, and six others, all armed with heavy clubs, arrested Adam Forney at his home and carried him off to the Baltimore jail on the charge of resisting the officers of the law. Forney was subjected to very rough treatment and in the struggle that attended the arrest his wife, Louise, and his daughter, Eve, were badly beaten with clubs. In Baltimore Forney entered bail for his appearance at court. The provincial authorities of Pennsylvania at once took measures to defend Forney on the ground that the arrest was made within the jurisdiction of Pennsylvania. A Maryland lawyer was retained to defend Forney at the trial. But a little investigation revealed the fact that the house where Forney had been arrested was actually within the limits of Digges's original tract. The case thus ceased to interest the Pennsylvania authorities and Forney was left to his own defense. How the case was settled is nowhere recorded but there was probably nothing more than the imposition of a fine, for we soon find Forney at his home again. ${ }^{22}$

${ }^{21}$ Archives, I: $685 \mathrm{f}$. and $694 \mathrm{f}$.

22 Archives, I: 724-733. 
During the week following Forney's arrest a formal complaint was drawn up by the German settlers on the "Disputed Land" and sent to Thomas Cookson, setting forth the facts of Forney's arrest and brutal treatment and asking Cookson to intercede with the governor "that sum Releef may be spedely, for it is vary hard for us to live af ter this manner, to be toren to pesis." This was signed by Martin Kitzmiller, Martin Brin, Abraham Sellen (Sell), Hanry Sellen, "and numerous others."

In 1749 a petition was presented to Governor Hamilton signed by Hendrick Seller (Henry Sell) and thirteen others, stating that they were all settled on the tract included by Digges in his resurvey of 1745 , that they all held Pennsylvania warrants for their land, that Digges was threatening to sue them unless they would pay him Ioo pounds Maryland currency, and that they were in constant danger of being forced from their plantations, carried to Maryland and there confined. The petitioners asked that some speedy means be devised for their relief. ${ }^{24}$

This unsettled condition of affairs continued until in I 752 it led to the tragic shooting of Dudley Digges, son of John Digges. Martin Kitzmiller, with his wife and three sons, Jacob, Leonard, and John, was settled on a tract of roo acres continguous to Digges's Choice. Kitzmiller had bought the improvements on this tract from John Lemmon in I736. Lemmon had recognized the right of Digges to the land but had not yet paid Digges for the land when he sold the improvement to Kitzmiller. When Kitzmiller came into the possession of the improvements he refused to acknowledge Digges's right to the land and secured a warrant from Pennsylvania for the 100

23 Archives, I: $724 \mathrm{f}$.

24 Archives, II: 28. 
acres. This plantation, including a mill and a blacksmith shop, lay entirely outside the limits of Digges's original survey but within the bounds of his resurvey. Accordingly Digges sought to force payment from Kitzmiller. This Kitzmiller resisted. On February 26, I752, the sheriff of Baltimore County accompanied by several other persons, among them Henry and Dudley Digges, went to Kitzmiller's mill and placed Martin under arrest. Kitzmiller resisted arrest, his sons came to his rescue, and in the struggle a gun in the hands of Jacob Kitzmiller was discharged, killing Dugley Digges. The Marylanders then left the premises and Jacob Kitzmiller went to York and delivered himself into custody. John Digges represented that his son had been murdered and appealed to the Maryland authorities for justice. The president of the Maryland council at once laid claim to jurisdiction in the case and demanded that Kitzmiller be delivered to Maryland for trial. But the council of Pennsylvania established the fact that at the time of the royal order of 1738 Digges was not in possession of the land where the tragedy had taken place and that any possession that he may have acquired under Maryland authority subsequent to 1738 was in violation of the royal order. The case therefore was ordered to be tried at York on October 30, $175_{2}$, and the province of Maryland was invited to submit at the trial whatever evidence they had to show that the place of shooting was in their jurisdiction. ${ }^{25}$ But at the trial of the case before the court of Oyer and Terminer held by the supreme judges at York the jurisdiction over the disputed land was shown to belong to Pennsylvania. It also appeared from the evidence in the case that the shooting of Dudley Digges was in all probability an accident, and Jacob Kitzmiller

25 Colonial Record, V: 582-597; Archives, II: 70-83. 
and his father were acquitted. ${ }^{26}$ But this tragedy helped to sober the disputants somewhat and no further acts of such violence occurred, although the land disputes continued to disturb the peace of the settlement for almost a decade.

Thus did the German pioneers in York County unwittingly become the means of resisting the encroachments of the Marylanders at both of their points of collision with the Pennsylvania authorities. But both in the eastern part of the county and in the southwestern part, they stood their ground for the most part quite loyally and with true German tenacity endured the hardships of improving their lands and maintaining their rights until at length the cumbersome negotiations of the proprietaries determined the respective spheres of the two provinces and thus brought to the settlers the peace and prosperity in search of which they had left their native land. The running of the "Temporary Line of I739" according to the royal order of King George II settled forever the difficulties in the Kreutz Creek Valley. Thomas Cressap, who had been captured and imprisoned in Philadelphia, was released and returned to Maryland. ${ }^{27}$ The Pennsylvanians who had been carried off from that region and imprisoned in Baltimore jail were also set free. ${ }^{28}$ The Kreutz Creek Settlement then began to grow rapidly.

But the German settlements on Digges's Choice were not freed from the disturbances of border difficulties for some years after the royal order had been issued. The vexed question of the exact bounds of Digges's grant under

26 From the full account of the trial which Richard Peters, secretary of the province, wrote to the Penns in England immediately after the trial.

27 Col. Rec., IV : 266 .

28 For example, Nicholas Perie, Col. Rec., V: 22:5. 
his original survey and the further question concerning his right to lands north of the "temporary line" under a Maryland "resurvey" of I 745, continued to disturb the settlers in the southwestern part of the county and tended to discourage settlement there. The confusion continued, as we have seen, until 1752 when at the noted trial of Jacob Kitzmiller at York, in the presence of the attorneygenerals of both provinces, the bounds of Digges's original survey were accurately determined and the principle was recognized that the lands north of the temporary line of I 739 which Digges had added to his original survey by his resurvey of I 745 were Pennsylvania property according to the royal order, and that therefore the Pennsylvania titles of the German residents on those lands were entirely valid. This decision, although it did not determine ultimately in what province those lands were, nevertheless served greatly to pacify the settlers in the southwestern part of the county and gave impetus to the influx of immigrants into that fertile region. Finally with the amicable adjustment of the boundary question by the proprietors in England in 1763 and the completion of Mason and Dixon's line in 1767 all the inhabitants of this neighborhood of Hanover found themselves the unquestioned citizens of the province of Pennsylvania.

Meanwhile the two settlements whose beginnings we have described were gradually growing in numbers and extent. New accessions were being made in constantly increasing numbers. The Kreutz Creek Settlement naturally grew more rapidly than that on Digges's Choice. As new immigrants arrived in the valley they pushed farther and farther to the west and southwest, selecting always the choicest farming lands for their settlements. Thus the settlement expanded from the Kreutz Creek 
Valley into the Codorus Creek Valley and up this valley until it joined the German settlement at Hanover. So that in 1749 when York County was erected there was an almost continuous stretch of German plantations across the entire breadth of the county from the mouth of the Kreutz Creek in the east, across the very center of the county, to the banks of the Conewago in the southwest. This stretch of valley has been the home of the German element in the county ever since the planting of these earliest settlements. In 1740 the number of taxables in the county is said to have been over six hundred. More than three fourths of these were Germans, the rest being the English who had settled in the northern part of the county and the Scotch-Irish who had taken up their abode in the southeastern part. In I 749 the number of taxables reached almost fifteen hundred, the same proportion of Germans still obtaining.

But more than a decade before York County was separated from Lancaster County events had begun to shape themselves for the formation of a third German settlement in our county. Already in September, r733, Rev. John Caspar Stoever, coming from Lancaster County, visited his German brethren west of the Susquehanna, gathered them together from the whole district of the Kreutz Creek and Codorus Creek Valleys, and organized them into "Die Evangelisch-Lutherische Gemeinde an der Kathores." The first Church Record of this congregation contains on its fly-leaf the names of twenty-four of these earliest Germans who contributed to the purchase of the book. ${ }^{29}$ Pastor Stoever baptized I9 I persons and married 34 couples in this congregation before the close of his

${ }^{29}$ Now in the possession of the Rev. Dr. G. W. Enders, the present pastor of the Church. 
pastorate at the end of $1743 .^{30}$ His successor, Rev. David Candler, organized the Lutheran Church on Digges's Choice, "Die Evangelisch-Lutherische Kanawagische Gemeinde," in April, 1743. These organizations were some of the guarantees of permanency and the harbingers of healthy growth of these settlements.

By the year I739 the settlements immediately west of the Susquehanna had become so numerous and their Pennsylvania citizenship so obvious that the Provincial Assembly by special act added a new township to Lancaster County, the township of Hellam, which included most of what is now York County. In that same year a petition was presented to the Lancaster court by the inhabitants of Hellam Township praying for the opening of a public road between the Susquehanna and the Potomac. The petition was granted and of the six viewers appointed to locate this the first public road in the county at least four were Germans, namely, Michael Tanner, Christian Croll, Henry Hendricks and Woolrich Whisler. The road began at a point between the lands of James Wright and Samuel Tayler on the west bank of the Susquehanna immediately opposite the plantations of John Wright ${ }^{31}$ and extended thence along the entire route of the German plantations through the Kreutz Creek and Codorus Creek Valleys, past Adam Forney's land (now Hanover) and Kitzmiller's Mill on the Conewago Creek, to the provin-

${ }^{30}$ A history of this Church is to be found in the article by the Rev. Dr. B. M. Schmucker in the Lutheran Quarterly, Vol. XVIII, 1888, pp. 473-529, "The Lutheran Church in York, Pa." A general history of the Lutherans on the Codorus and the Conewago is presented in Schmauk's "Lutheran Church in Pennsylvania," Vol. I, Chapter XIV, pp. 357-393.

31 To this point a road had been constructed from Lancaster in 1734 . 
cial line. ${ }^{32}$ It was known as the Monocacy Road and covered a distance of 34 miles.

Thus the steps were taken in the German valley which were soon to lead to a county-seat for a new county and ultimately to give to Pennsylvania one of her most flourishing cities. For it was only two years after the ordaining of the Monocacy Road that a movement began which resulted in the establishing of a third German settlement in the county, destined in the course of time greatly to outgrow the other two and to play a significant rôle in national affairs. This was the town of York. In October, I74I, by order of the Penns, Thomas Cookson, Surveyor of Lancaster County, crossed the Susquehanna River and proceeded "to survey and lay off in lots a tract of land on the Codorus where the Monocacy Road crosses the stream." This point is as far west of the Susquehanna as Lancaster is east of it. The prospective town on the Codorus received the name York, a neighboring city of Lancaster in England. The site selected for the new town lay on both sides of the creek but only the part east of the stream was laid off into lots. Applications for lots were then invited and in the month following the survey, November, I74I, twenty-three lots were reserved by intending citizens. Of these at least twenty-one were taken by Germans, George Swope purchasing four, George Hoke two, and the others each one as follows:
Jacob Welsh
Baltzer Spangler
Michael Swope
Christian Croll

\author{
Michael Laub \\ Zachariah Shugart \\ Nicholas Stuck \\ Arnold Stuck
}

32 Vide Gibson's “History of York County," p. 322. Michael Tanner was also one of those appointed in 1766 to view the road southward from Hanover to the line between the provinces. 
Samuel Hoke

Hermanus Butt

Jacob Grebill

Joseph Hinsman

Andrew Coaler
Matthais Onvensant

Martin Eichelberger

Henry Hendricks

and

John Bishop.

All except the last two are certainly German. Hendricks is probably German, and John Bishop is very probably the Anglicized form of Johannes Bischof, who arrived at the port of Philadelphia October 27, I739.

But an application for a lot did not in every case mean that residence in the new town was effected. A yearly quit-rent of seven shillings sterling was required by the proprietors for every lot that was taken up. James Logan, who was sent to regulate and supervise the affairs of the incipient town, imposed a condition upon the applicants by which each applicant was required within one year of the time of his application "to build upon his lot at his own private cost one substantial dwelling-house of the dimensions of sixteen feet square at least, with a good chimney of brick and stone, to be laid in or built with lime and sand"; otherwise his claim should be void. This was not an easy condition for the poor immigrants of that day to comply with. Few of the pioneer settlers had the means to build such houses, and of the few who had the means nearly all had gotten them through farming and this occupation they intended to continue now that they had crossed the Susquehanna. Consequently most of the newcomers to the county were not disposed to take up their residence in town but preferred to locate upon the fertile farms adjacent. ${ }^{33}$ Accordingly the town grew

33 George Swope and Baltzer Spangler afterwards kept public houses in the town. But Adam Miller was the first person to receive permission to keep a public house there. Vide Rupp's "History of Lancaster and York 
slowly at first. Two years after it had been laid out seventy lots had been applied for, but many of these had been forfeited because of the failure to build and only eleven houses had actually been built, although several more were in prospect, among them a Lutheran and a Reformed house of worship. ${ }^{34}$ Practically no public improvements had been made. In 1746 forty-four additional lots were reserved and in October, I749, when York became a county-seat, the town consisted of sixtythree dwelling houses and two churches. ${ }^{35}$ During the next five years under the efficient supervision of George Stevenson the town began to thrive and by the end of I 754 contained 210 dwelling houses. In 1764 when the town of Hanover was laid out, York was already growing rapidly. It was in the very center of a flourishing agricultural community and had attracted wide attention. Its population was predominantly German and it was to the thrifty German farms lying all about it that the town owed its growth and prosperity. ${ }^{36}$

The origin and the growth of this settlement at the

Counties," p. 574. In I754 George Stevenson wrote from York: "The timber of the town land was all destroyed before I came here; the inhabitants ever since, have bought all their timber for building and firewood, very dear, of the adjacent farmers, which is discouraging to poor settlers, and few rich people settle here." See letter of October 26, quoted in Gibson, p. 516 .

34 Vide letter of James Logan to Thomas Penn, August 30, 1743. Among the Official Penn Manuscripts.

$35 \mathrm{~A}$ few persons had taken possession of lots and built homes on them without securing a legal title. The names of such town squatters are Jacob Billmeyer, Jacob Fakler, and Avit Shall. They were required to give up their possessions to the agent of the proprietaries in 1751. Rupp's "History," p. 575 .

${ }^{36}$ Referring to the German citizens who constituted nearly the entire population of the town Thomas Penn wrote in 17615 ' of "the flourishing state to which the town hath arrived through their industry." 
intersection of the Codorus Creek and the Monocacy Road cannot be understood entirely apart from the settlers in the country round about. Eight or nine years before York had been laid out as a town a number of Germans had taken up their abodes on the inviting lands in that vicinity. They had not come from the same region as that from which the original settlers on the Kreutz Creek had come. And in their new homes in York County they were for the most part too far west to be affected by the border disturbances which embroiled the settlers in the Kreutz Creek Valley, although they had migrated into the county almost simultaneously with the settlers on the Kreutz Creek. Their plantations lay about the point where the Kreutz Creek Valley ceases and merges into the Codorus Creek Valley. From that point they stretched north and northeast along the course of the Codorus and some of them also stretched southwest along that creek.

Here these Germans had settled chiefly as squatters, undisturbed by the Indians and tacitly tolerated by the Pennsylvania authorities who knew that these settlers would secure warrants in the course of time. For a long time they constituted a group quite distinct from the settlers in the Kreutz Creek Valley farther east. ${ }^{37}$ Many of them had arrived here as early as 1733 and it was from their number that Pastor Stoever, in September of that year, gathered the members for the first church organization west of the Susquehanna. The location of the members of this congregation gave the new organization its name, the "Church on the Codorus." And the list of the

37 The Lancaster County authorities knew that there were Germans settled at the west end of the Kreutz Creek Valley, for Blunston wrote on January 16, I'737: "Most of the Dutch not taken are come away that live towards this end of the valley." 
names of the individuals who helped to purchase the first record book for that Church doubtless embraces the names of most of the German settlers in that neighborhood in the fall of $\mathrm{r} 733$. Of this list of twenty-four names only four (Christian Croll, Philip Ziegler, Jacob Ziegler, and Michael Walck) are familiar to us from our study of the names of settlers in the Kreutz Creek Valley. The others $^{38}$ were beyond the reach of those disturbances. Some of these German settlers along the Codorus afterwards drifted into the town of York. But most of them remained upon their thriving plantations and constituted the base of supplies and the ground for the prosperity of the new town. These settlers and their plantations must therefore be regarded as an integral part of the third German settlement in the county.

These, then, were the earliest German settlements in York County. After five years of border difficulties in the Kreutz Creek Valley and two decades of turmoil over the boundaries of Digges's Choice, the development of these

38 These are as follows:

Martin Bauer
Johannes Bentz
Joseph Beyer
Paul Burkhardt
John Adam Diehl
Carl Eisen
Baltzer Knetzer
Christof Kraut

Gottfried Mauch

Nicholas Koger

Jacob Scherer

Mathias Schmeiser

George Schmeiser

George Zimmermann
Heinrich Schultz

Valentine Schultz

George Schwab

George Ziegler

Heinrich Zanck

and

One illegible.

A complete list of males to whom Pastor Stoever ministered during the ten years of his pastorate $\left(1733^{-1743)}\right.$ as gathered from the entries in his record, includes exactly roo names. Of these at least $\mathrm{I} 4$ are names that occur in the documents concerning the Kreutz Creek Settlement. This indicates that some of the settlers in that first settlement, probably those who were Lutherans, availed themselves of the ministrations of the pastor who served the settlement on the Codorus. 
German settlements, stretching from one end of the county to the other, went steadily and peacefully forward until the outbreak of the French and Indian War. They concentrated, as we have seen, along the line of the Monocacy Road and this in turn followed for the most part the ancient Indian trail which had marked the course for early German missionary and pilgrim.

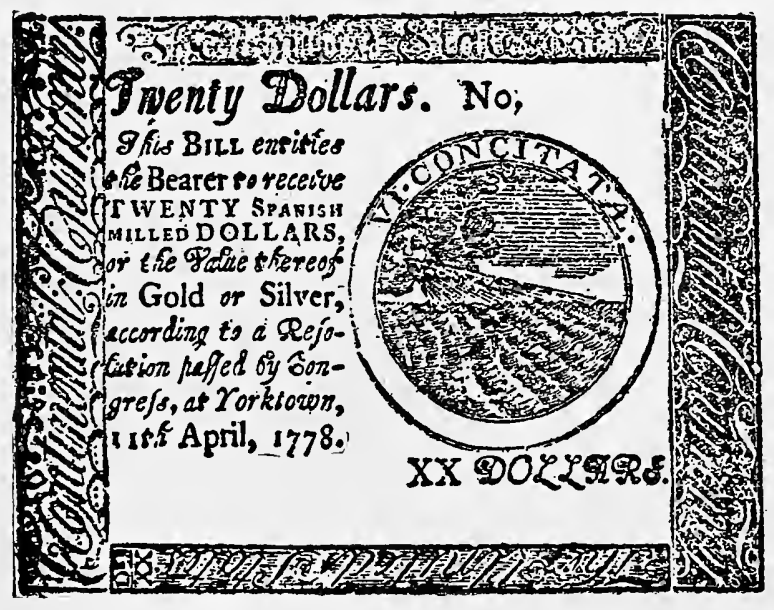




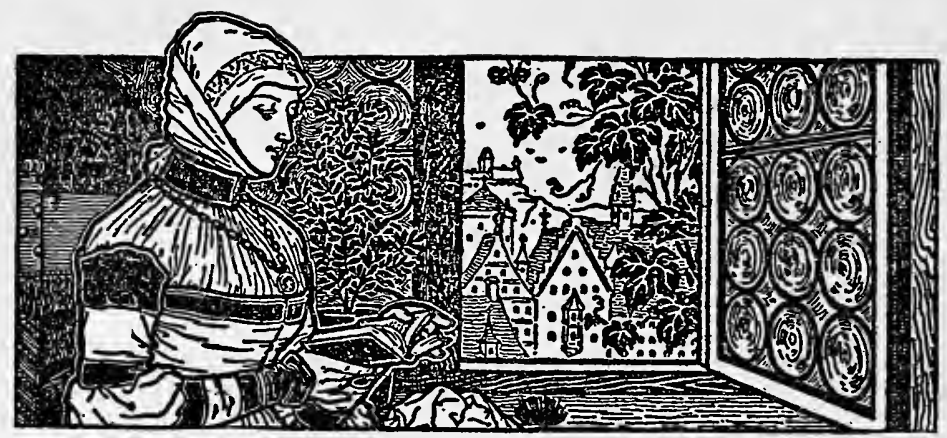

CHAPTER V.

\section{Whence the Germans Came and Why.}

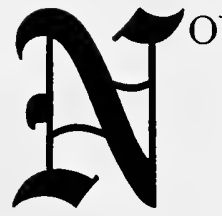

OW that we have seen how the German element in York County had its beginning there, we cannot fail to be confronted by the larger and prior question as to the origin of these Germans before they settled on the banks of the Kreutz Creek, the Codorus and the Conewago. Why did they come to America? Where did they come from when they settled in York County? And how did they come to settle the particular parts of the county which they did and which their descendants have occupied to the present day?

Of the reason why the Germans left their native homes and braved the discomforts and dangers of an ocean voyage to take up their abodes upon the unsettled newlands of America we have a very clear intimation in a declaration wrung from them by their distresses in our county shortly after their settlement here. In the course of the proceedings concerning the "revolt of the Germans" in the Kreutz Creek Valley from Maryland authority and their return to Pennsylvania allegiance, the Germans had 
occasion to send an answer to the Governor of Maryland (I736). In this statement they take occasion to explain why they left Germany and how they came to locate in what is now York County. For they set forth

that being greatly oppressed in their native country, principally on account of their religion, they resolved, as many others had done before, to fly from it. That hearing much of the justice and mildness of the government of Pennsylvania, they embarked in Holland for Philadelphia, where on their arrival they swore allegiance to King George and fidelity to the proprietors of Pennsylvania and their government. That repairing to the great body of their countrymen settled in the County of Lancaster, on the east side of Susquehannah they found the lands there generally taken up and possessed, and therefore some of them by licenses from the proprietors of Pennsylvania, went over that River and settled there under their authority, and others according to a common practice then obtaining sate down with a resolution to comply as others should with the terms of the government when called on, but they had not been long there until some pretending authority from the government of Maryland, insisted on it that that country was in that province, and partly by threats or actual force and partly by very large promises, they had been led to submit to the commands of that government." Then they recount the ill treatment they have received at the hands of the Marylanders. "This uncommon and cruel usage" is only one of a number of arguments by which "we are persuaded in our own consciences we are clearly within the province of Pennsylvania." "We could not therefore but believe ourselves obliged in conscience in the honest discharge of the solemn engagements we had entered into at our first arrival in Pennsylvania, to return to our obedience to its proprietors as soon as we discovered we were truly seated within its limits." And in conclusion they appeal to the Governor's consideration against " the treating of a parcel of conscientious, industrious, and peaceable people, like rebels, for no other reason than ... because we are 
convinced of the mistakes we had been lately led into by the false assertions of persons of no credit."1

From this writing it is clear that these Germans had left their native land for a threefold reason, partly because of political oppression and severe religious persecutions at home, partly because of the example of many who had preceded them, and partly because of the alluring accounts they had heard about Pennsylvania. They had gone first to Lancaster County because most of the Germans in Pennsylvania were located there. They had continued through Lancaster and across the river and into what is now York County and had settled there, most of them as squatters without licenses but intending to take out licenses in course of time. Here their ignorance of the language of the government and their lack of acquaintance with political intrigues made them the easy victims of evil schemes. Their own motives were peaceful but they were inveigled into procedures which involved them in strife and unrest. The stubborn dispute of the provincial governments concerning the jurisdiction over the lands on which the Germans had settled entailed unhappy consequences for the newcomers and for a time threatened seriously to disturb the peace and permanence of their settlement.

Now the grounds: of this religious persecution and the other kinds of oppression which these Germans had suffered in their native country and which they give as their reason for fleeing from Germany, are of no little importance for our subject. They carry us across the ocean and back more than two centuries into the past but they help us to understand the character and class of the immigrants,

1 Archives, I: 492 f. This statement was signed by about sixty hands. Col. Rec., IV: 57 . 
the circumstances under which they left their homes and came to the New World, and the distinctive characteristics which they manifested in their lives and habitations after they arrived in York County. For that reason we must pause to enumerate, in outline at least, the causes of the German immigration to Pennsylvania in the eighteenth century. ${ }^{2}$

The chief causes are of two kinds. A long series of destructive wars, continued religious persecution, and re-

2 The sources of information concerning German immigration to America are many and varied. A complete bibliography of works relating to Germans in the United States far exceeds 10,000 titles. The first volume of Professor A. B. Faust's "The German Element in the United States" (r909) gives a faithful summary of the history of German immigration into America. Chapters II-V deal in a general way with the immigration into Pennsylvania. At the close of Volume II Professor Faust presents a rather full bibliography compiled from European and American sources and containing nearly two thousand titles.

In the first chapter of Professor Oscar Kuhns's reliable volume on "The German and Swiss Settlements of Pennsylvania" (rgor) we have a brief but thoroughly accurate portrayal of "the historic background" of the immigration, and chapter two gives a very clear account of "The settling of the German counties of Pennsylvania." This work when read in connection with Professor Faust's two volumes serves to impress the student with the distinctive history and the distinctive qualities of the Pennsylvania Germans in contrast with the more modern waves of German immigrants. This distinction is not clear in Faust. The original Pennsylvania German settlers were part and portion of the American colonists and their spirit and ideals and characteristics were very different from those of the modern German Americans. Professor Kuhns's volume also contains a bibliography far less extensive than Faust's but much more useful for the general student.

For our brief survey of the story of Pennsylvania German immigration at the beginning of this chapter we have used besides general works like those of Faust and Kuhns and besides the works referred to in the other footnotes, such special works as Häusser, "Geschichte der Rheinischen Pfalz," Heidelberg, 1856; O. Seidensticker, "Geschichte der Deutschen Gesellschaft von Pennsylvanien, 1764-1876," Philadelphia, 1876; and the volumes of "Proceedings of the Pennsylvania German Society." 
lentless oppression by petty tyrants, had rendered existence at home almost unendurable, while favorable reports from earlier settlers beyond the Atlantic, more plentiful means of transportation, and an innate desire for adventure ( $W$ anderlust), made the attractions of the foreign shore almost irresistible. These two sets of historical causes operated as mighty forces leading the Germans to turn their backs upon the homeland which they loved and to embark for a land of peace and plenty, as they thought.

The first of the series of wars that rendered life in Germany intolerable was the Thirty Years' War. This was the most awfully destructive and demoralizing struggle in history. Its horrors beggar description. It set Germany back in the scale of civilization at least two hundred years, so that she is only in the present day recovering her pristine position in the onward march of the nations. The dire consequences of the war fell most heavily upon the peasants, the foundation of the nation and the root of its growth. In many parts of the country in the course of the war 75 per cent. of the inhabitants were destroyed, 66 per cent. of the houses, 85 per cent. of the horses, and over 80 per cent. of the cattle. ${ }^{3}$ These multiplied woes of war fell with greatest force upon southwestern Germany, especially the Palatinate. The Palatinate may be roughly defined as that part of Germany which lies about the left bank of the Rhine between Mayence and Spires. Two centuries ago it was one of the integral parts of the empire. It was this fair province that suffered most from the ravages of war in the seventeenth century. The Elector Palatine Frederick $\mathrm{V}$ himself precipitated the war and thus attracted to his own fertile land the full fury of that awful

${ }^{3}$ Gustav Freitag, "Bilder aus der deutschen Vergangenheit," Vol. III, 234. 
storm. In I6I9 the Elector accepted the crown of Bohemia and thus became involved in war with the strong house of Austria. Retribution came swiftly and terribly. He was very quickly driven from his winter throne, deprived of his new crown, put to the ban, and robbed of his lands on the Rhine, which became at once the object of repeated spoliation for all the lawless hordes of dissolute soldiery. For years in succession the grim shadows of famine and pestilence brooded darkly over the land. So great was the desolation that in the last years of the war neither friend nor foe any longer entered the Palatinate, the melancholy fact staring them in the face that there was no longer anything to steal,- - the most fertile area of Germany had become a desert.

The peace of 1648 endured but a few years so far as southwestern Germany was concerned. The survivors of the war had begun the tedious work of reviving their homes, their fields, and their fortunes. The new Elector granted religious freedom and this fact together with the liberal terms under which lands were granted to colonists attracted some of the best products of neighboring countries. The country began to prosper anew and was well on the way to recovery from its recent distresses, when in I 674 the blood-curdling cry of war rang out once more through the land, and the painful efforts of more than two decades remained fruitless. This time France was the aggressor. War was on between France and Holland, the War of the Protestant Netherlands, 1672-1678. From its position the Palatinate was most exposed to the ravages of the contending armies. For it was one of the borderlands of the German Empire, fair and prosperous, an attractive mark for the marauding bands of military robbers 
and therefore destined to be crushed between the two millstones of the opposing powers. Louis XIV ordered the beautiful Palatinate to be devastated, to render it useless to his enemies. The work of devastation was done thoroughly. Once more the doleful tale of destruction and misery, of burning city and homeless peasant, is recorded, and it was at this point in the history of the Palatinate that the first faint beginnings of the emigration to Pennsylvania took place. But greater woes were yet to come to the Rhineland.

After a brief respite of less than ten years the War of the Palatinate ( $1688-1697$ ) was begun. Louis XIV had laid claim to the entire Palatinate in the name of his sister-in-law. When the countries of northern Europe leagued themselves together in a mighty coalition to withstand this new effrontery Louis hurried a large army into the country. Then, because he could not hold the conquest he had made and because the Palatines had harbored the Huguenots expelled from France, the covetous French monarch gave summary orders to "burn the $\mathrm{Pa}$ latinate." Breathing forth fire and slaughter his base hyenas of war leaped wildly upon the defenceless land. Crops were destroyed, villages and towns were reduced to ashes, and more than a hundred thousand innocent and helpless peasants were rendered homeless.

The war lasted seven years and when at length in 1697 the smoke lifted from the last glowing embers of the various parts of the Palatinate, there sat upon the throne, one John William, an ardent Romanist. Now religious persecution was added to economic bankruptcy. The persecution of Protestants, Lutherans and Reformeds, was carried on systematically. Their Church property was 
confiscated to a very large extent and the worshippers in many cases expelled from the country. The sects, such as the Mennonites, Quakers, and Huguenots, were summarily driven from the land. Hundreds of petty persecutions on person and property were made. And this continued for nearly a century. The ravages of war followed one another in rapid succession. The War of the Palatinate had scarcely closed ( 1697) when the War of the Spanish Succession broke out ( I 7OI-I 7 I4). Then followed the War of the Austrian Succession (I74I-1747). All of these were sorely felt in the Palatinate and other parts of southwestern Germany. Meanwhile the cruelties of religious persecution continued unabated. For a long period each new prince of the Palatinate forced a change of religion on his subjects. The injustice and the petty tyrannies of the rulers made life a constant burden and fostered a widespread discontent. The continued disturbances of war and religious persecution soon began to entail dire effects of a social and economic nature. For in the course of the late seventeenth and early eighteenth centuries nearly 500,000 Palatines, Wuertembergers, and Swiss, were ruthlessly expelled from their homes. Exile was followed by famine, famine by pestilence, and at last all the finer impulses of the heart were threatened with complete extinction in the gross wretchedness of brutalizing despair. It is not a matter for surprise, therefore, that the Germans in the midst of such trials set their faces resolutely towards the west in the hope of finding a better land where peace and quiet reigned and where there was liberty of conscience. And coming as they did from such conditions of long-continued oppression and ruin, we cannot expect them, after they arrive in the New World, to take a place at once in the forefront of social and literary circles. 
If we take a general view of the streams of German immigration which flowed into Pennsylvania before the Revolutionary War, we can distinguish three well-defined periods. ${ }^{4}$ The first period extends from 1683 (when the first settlement was made under William Penn at Germantown) to I7 Io. During this period the number of those who came was small, probably not exceeding in total 500 souls. They all remained in or near Philadelphia, and this period of immigration had therefore no direct influence upon York County. The second period from 17 ro to 1727 , is marked by a considerable increase in the number of immigrants, although there is as yet no steady influx of large numbers. Perhaps I4, Ooo would be a liberal estimate for the immigration during the second period. ${ }^{5}$ The year 1727 marks an epoch in this matter for it was then that the immigration began to assume large proportions and that official statistics began to be kept. The third period therefore begins with the year 1727 and extends to the outbreak of the Revolutionary War. During this period the numbers of German immigrants swell to enormous size, and by the year I 775 the grand total of Pennsylvania Germans must have been no less than I I0,000 or about one third of the total population of the state, a proportion which seems to have kept itself practically unchanged down to the present day.

When the Germans fled from the hardships of their life in southwestern Germany and in Switzerland they invariably took their course down the Rhine. The earliest settlers of Germantown made their way directly from Hol-

4 This division of periods is the one presented by Kuhns, p. $3 \mathrm{I}$.

5 Vide Kuhns's refutation (German and Swiss Settlements, pp. 52-54) of Rupp ("Thirty Thousand Names," pp. I f.) and Wayland ("German Element of the Shenandoah Valley," p. 27\%). 
land to America. But after a few years, at the instigation of Queen Anne who had compassion on the suffering exiles and who was earnestly seeking settlers for her own American colonies, the exiles began to cross the Channel into England where they threw themselves upon the kindness of the Queen's government. Their numbers sometimes embarrassed the English government. In I 709 as if by sudden common impulse over I3,000 Palatines swarmed into London and asked to be sent to America. Of this number over 3,000 were sent to the colony of New York and settled along the Hudson and Mohawk Rivers. ${ }^{6}$ Here after a decade of varying fortunes, insuperable difficulties arose in regard to the titles to their land. They were forced to leave the homes which they had built with the labor of many years and in 1723 three hundred of them painfully made their way through the wilderness of southern New York to the headwaters of the Susquehanna and floated down the river until they came to the mouth of the Swatara Creek, opposite the northern part of York County. Up the Swatara they made their way to the district now known as Tulpehocken, where they settled Heidelberg and Womelsdorf. ${ }^{7}$ They were followed in 1728 by a large party from New York under the leadership of Conrad Weiser. Thus we have the beginnings of Pennsylvania Germans in Berks and Lebanon Counties. This became one of the gathering points for German immigration into Pennsylvania and from this region came not a few of the very earliest settlers in York County. The Germans had

${ }^{6}$ The experiences of the Germans in the colony of New York are graphically depicted by Rev. Sanford H. Cobb in his "The Story of the Palatines: an Episode in Colonial History," 1897 .

7 Vide supra, p. 20. For an accurate and detailed history of the Tulpehocken settlement and its subsequent development, vide Schmauk's " $\mathrm{Lu}$ theran Church in Pennsylvania," Vol. I, pp. 433-576. 
made their first and last effort in colonial New York. They began to advertise among their people in the homeland what ill treatment they had received in New York and how favorable were the conditions for settlement in Pennsylvania, and henceforth the Germans began assiduously to avoid New York and the mainstream of their immigration came to Pennsylvania.

Another important distributing center of Pennsylvania Germans before the Revolution was Lancaster County. The settlement of this county was due primarily to the religious persecutions of the emigrants rather than to economic causes. The movement began in 1710 and had its chief source in Switzerland. For nearly a century the doctrines of the Mennonites had been flourishing in Switzerland. ${ }^{8}$ But like the Quakers in England and New England, the Mennonites in Switzerland were the victims of systematic persecution. From time to time individuals and families made their way across the Swiss frontiers and sought refuge among their brethren in the faith on the banks of the Rhine. Thus was formed a chain of Mennonites all the way from Switzerland to Amsterdam. And when these plain but serious people heard the favorable reports concerning the peace and prosperity of their brethren at Germantown, Pennsylvania, and when their awful persecutions in Switzerland continued undiminished, many of them resolved to try their fortunes in the land of William Penn. Accordingly in I 7 Io some hundreds, perhaps thousands, of the most desirable citizens of Switzerland and the Rhine Valley arrived at Philadelphia and selected as their settlement a tract of I0,000 acres on the Pequea Creek, Conestoga, just east of the Susquehanna River, in what is now Lancaster County. These industrious and

${ }^{8}$ D. Musser, "The Reformed Mennonite Church," 1873. 
gentle Mennonites lived on good terms with the Indians and by the aid of the German immigrants that soon poured into the county they made Lancaster the garden-spot and pride of Pennsylvania.

After these successful beginnings had been made, in Germantown, in the Lebanon Valley, and in Lancaster County, the tide of German immigrants began to flow strongly. The influence was contagious. The ancient Wanderlust of the Teutons revived in the breasts of their descendants. The settlers in America returned favorable reports to their friends and relatives still bearing their hard conditions in the homeland. Tracts were published describing utopian conditions of the New World. Shipowners hired agents to stimulate the exodus from the valley of the Rhine. Lands, farms, and plantations were freely offered to every settler for a small amount of purchase money. Many representatives of every class of society in that overburdened population of Europe yielded to the alluring prospect held out by the New World so full of opportunity for the industrious. Besides the great body of political refugees and those persecuted on account of their religion there were also considerable numbers of others, such as the industrious artisan seeking opportunity to maintain his family, the overburdened tenant groaning under a load of taxes and labors, the unfortunate merchant looking for better investments and more promising speculations, the impecunious nobleman seeking a chance to retrieve his lost fortune, the romantic spirit in search of adventure and desiring to hunt and trap unrestrained in the primeval forests, and the poverty-stricken redemptioner fleeing the starvation that threatened him at home. All these helped to swell the stream westward. With the year 
I 727 the Germans began to come in such large numbers that the colonial government grew alarmed and began to keep official lists of these immigrants exacting from each man an oath of allegiance to the British government. The largest contingent of Germans continued to come from the Palatinate but there were also considerable numbers from the neighboring states of Germany.

If now the question be asked why this German immigration focused thus upon Pennsylvania to the exclusion of the other provinces the answer is fourfold. In the first place, before the German immigration began, William Penn, himself half German by birth, had made two journeys to Holland and Germany and had made many acquaintances among those who were the objects of religious persecution in the Fatherland. When therefore the great Quaker received his grant of land in America these people among whom he had visited in Germany were naturally interested in his project to establish a colony in the New World and specially susceptible to the arguments presented in his pamphlet calling for colonists. When they crossed the ocean they were received by Penn and settled at Germantown. Those who followed them across the ocean naturally followed them also into Penn's province. Thus the tide began to flow into Pennsylvania.9

In the second place, when the stream of German immigration into America grew stronger and the influence of the English government tried to determine its direction, the experiment of sending Germans to New York was tried. But, as we have seen, it was unsuccessful. The Germans in New York soon became involved in serious

9 John Fiske in his "Dutch and Quaker Colonies" (Vol. I, p. 35I') agrees with Diffenderffer in assigning Penn's travels in Germany in 1671 and 1677 as the chief cause in directing German immigration to Pennsylvania. 
difficulties with the English there. They became convinced that the colonial authorities were unjust to them, and that, too, because they were Germans. Many of them removed to Pennsylvania where they found conditions quite satisfying. Then they sent word back to the Fatherland establishing a veritable prejudice against New York and strongly urging their friends to come to Penn's land. ${ }^{10}$

Thirdly, Pennsylvania was far more widely advertised in Germany than any other of the thirteen colonies. Immediately after Penn's grant received the royal confirmation in $\mathrm{I} 68 \mathrm{I}$ he published his ten-page compilation entitled "Some Account of the Province of Pennsylvania in America." This was translated into German ${ }^{11}$ by his counsellor Benjamin Furley and circulated broadcast in the valley of the Rhine. In I682 Penn sent forth his second advertisement of his province. It is entitled "Information and Direction to Such Persons as are inclined to America, More Especially Those related to the Province of Pennsylvania." This was a pamphlet of three and a half pages. It was quickly translated into German and spread abroad in the hope of attracting colonists to Pennsylvania. And another work that was translated and published in German" was Penn's "Brief Account of the

10 "The Germans, not satisfied with being themselves removed from New York, wrote to their relatives and friends and advised them, if ever they intended to come to America, to avoid New York, where the government had shown itself so unjust. This advice was of such influence that the Germans who afterwards went in great numbers to North America constantly avoided New York and always selected Pennsylvania as the place of their settlement."-Peter Kalm's "Travels in America" (r747 and 1748), Vol. I: 271. Kalm ascribes the comparatively slow growth of colonial New York to this treatment of the Germans.

11 "Eine Nachricht wegen der Landschaft Pennsylvania in America," Amsterdam, r68r.

12 Kurtz, "Nachricht von der Americanischen Landschaft Pennsylvania," 1682. 
Province of Pennsylvania." Then followed a number of more accurate and more detailed descriptions from the learned pen of Pastorius, leader of the original settlers of Germantown. These were all intended to arouse interest in Penn's colony among mercantile and pietistical circles. In this they succeeded, as results show. The chief of Pastorius's contributions to the advertisement of early Pennsylvania among the Germans was his "Umständige geographische Beschreibung der zu allerletzt erfundenen Provintz Pensylvaniae," published in I700. But among the advertising influences tending to draw German immigration to Pennsylvania, more important than any we have mentioned is Daniel Falckner's "Curieuse Nachricht von Pennsylvania." When Falckner returned to Halle after some five years of experience and observation in Pennsylvania, his friend, August Hermann Francke, who was then at the head of the Pietistic movement in Germany, propounded to him one hundred and three questions concerning the voyage to America and the condition of the country and its inhabitants, both European and Indian. To these questions Falckner replied in writing with frank and exhaustive answers. Questions and answers were published in book form at Frankfurt and Leipsic in 1702, and the work constituted for years the chief source of information for intending German immigrants. It passed through several editions, and became a mighty factor, not only in stimulating immigration to America but more particularly in directing it to the province of Pennsylvania. This vigorous advertisement among the Germans of the colony of Pennsylvania is entirely without a parallel in any other of the original thirteen colonies and it serves in no small de-

${ }^{13}$ Edited by Julius F. Sachse and published in Volume XIV of the "Proceedings of the Pennsylvania German Society," r 905. 
gree to account for the fact that German immigration to America concentrated upon this province. ${ }^{14}$

Finally, Pennsylvania made a special appeal to such as were driven from their homes on account of their religion. And for the majority of German immigrants to this country in the early eighteenth century the chief cause of their flight was religious persecution at home. The avowed purpose of Penn in establishing his colony was to provide religious freedom for the persecuted. He called his government a "Holy Experiment." His plan as embodied in his "Frame of Government" was to extend the benefits of complete religious and political liberty to all. This was one of the chief arguments advanced by Penn and his agents in advertising his province. Freedom of conscience was the glittering gem that they held out before the longing eyes of the oppressed. It was an argument that naturally appealed to multitudes in those days of chaotic religious conditions. Those who settled in Pennsylvania found their expectations in this respect entirely fulfilled. The result was that, among the Germans at least, Pennsylvania came to be regarded as preëminently a place of religious liberty, a refuge for the persecuted. And thousands upon thousands of those who were distressed in heart and conscience looked longingly towards the west and when

14 We have enumerated only the most important of the literary works that helped to induce German immigration to Pennsylvania. A detailed list of such works is found in Sachse's "Pennsylvania: the German Influence on its Settlement and Development. Part I: The Fatherland (14501700)," pp. 126-168. To this is added an Appendix, pp. 173-228, containing fac-similes of the title pages of the books and pamphlets that influenced the German emigration. This work is a reprint from Volume VII (1897) of "The Proceedings of the Pennsylvania German Society." A critical account of these works is also found in Winsor's "Narrative and Critical History of America," Vol. III: 495-516. 
the opportunity came to cross the ocean they aimed directly for the province of Pennsylvania. ${ }^{15}$

Such, in brief, are the reasons why Pennsylvania received the great preponderant mass of German immigration in colonial times. ${ }^{16}$ From the very beginnings of the history of the commonwealth the Germans have constituted one third of her total population and have at all times exercised a profound influence upon her progress and development. Other colonies had their German settlements. New York, New Jersey, Maryland, Virginia, North and South Carolina, Georgia, and Louisiana were not without their representatives from the Fatherland. But none of these, nor all of them combined, could compare in number or in influence with the German settlements in Pennsylvania, where they have always been the most

15 Christopher Saur, the celebrated Pennsylvania German printer and publisher, himself a Dunkard, says in his "Pennsylvania Berichte" of October I6, I754:

Pennsylvania ist ein solches Land, von desgleichen man in der gantzen Welt nicht höret oder lieset; viele tausend Menschen aus Europa sind mit verlangen hierher gekommen, bloss um der gütigen Regierung und Gewissensfreyheit wegen. Diese edle Freyheit ist wie ein Lockvogel oder Lockspeisse, welche den Menschen erst nach Pennsylvanien bringt und wann der gute Platz nach und nach enge wird, so ziehen die Menschen auch von hier in die angrentzende englische Collonien und werden also die englischen Collonien um Pennsylvanien willen mit vielen Einwohnern aus Deutschland besetzt zum Nutzen der Krone." Quoted in Seidensticker, "Geschichte der Deutschen Gesellschaft," p. I2.

16 Once the stream of German immigration had begun to flow strongly into Pennsylvania this fact itself served as an argument to attract others to this province. Thus in I7II Moritz Wilhelm Höen published the advice of the German pastor in London, Anton Wilhelm Böhme, under the title, "Das verlangte nicht erlangte Kanaan by der lustgräbern, etc." in which it is said: Im Gegentheil ist by Pennsylvanien zu mercken dass daselbst mehr Teutsche Colonien sich gesetzt haben als in einem einigen andern Theil der Englischen Plantationen in America; welche die jenigen zumercken haben die etwa von Lands-Leuten einige Hülfe und Hand-Reichung bey ihrer ersten Ankunft erwarten möchten." 
important single racial element within the borders of the state.

Coming into the province through the port of Philadelphia these immigrants only gradually made their way into the interior. Step by step they spread out in all directions from the city of Philadelphia. Germantown, the pioneer of all German settlements in America, now the twenty-second ward in the city of Philadelphia, remained predominantly a German city for more than a hundred years after its settlement and was chiefly prominent during the eighteenth century as the base for distribution of German immigration to the interior counties in southeastern Pennsylvania. The steady expansion of the German colony westward and southward in the eighteenth century is as interesting as the movements of their Alemannic ancestors in the fourth century and would be a fruitful theme for study. At the very beginning of the century we see the hardy German pioneers move out from Germantown and enter the unbroken wilderness, clearing the lands and turning the primeval forest into grain-covered fields. First they were content to remain in the vicinity of Philadelphia, in the counties of Montgomery, Lancaster, and Berks. Then as the population increased they made their way further and further to the west. As good lands became scarcer they crossed the Susquehanna and founded the counties of York, Adams, and Cumberland. Then they pushed northward into Dauphin, Lebanon, Lehigh, Northampton, and Monroe Counties. Towards the middle of the century Pennsylvania herself became a center of distribution of German immigration, which spread out from the Quaker commonwealth to all points south and west. As early as 1732 promising settlements had been made by 
II4 German Element in York County, $\mathrm{Pa}$.

Pennsylvania Germans in Western Maryland and in the Shenandoah Valley of Virginia. ${ }^{17}$ Germans from Berks County had settled at various places in the central and western parts of North Carolina. ${ }^{18}$ When Ohio was thrown open to colonists after the successful issue of the French and Indian War, Germans from Pennsylvania were among the enterprising pioneers who settled there. ${ }^{19}$ Still later they were in the forefront of that vast movement which wave by wave swept over the broad expanse of the west and northwest and won it to the purposes of civilization. The settlement of York County, Pennsylvania, is therefore simply one small step in the Teutonic occupation of colonial Pennsylvania and the general westward expansion of American population before the Revolution. Its relation to subsequent American history can easily be seen when it is regarded as one of the very first steps preliminary to the "winning of the west," an achievement in which the Pennsylvania Germans and the more recent German-Americans have always borne a highly important part.

More specifically it may now be asked from what part or parts of Pennsylvania the Germans came who first settled York County. Few of them came to our county directly from the port of landing as untried European immigrants. Most of them had reached America before the official lists of German arrivals began to be kept in 1727 and hence had some taste of American life before the val-

17 J. W. Wayland, "The German Element of the Shenandoah Valley" (r9o7), p. 33; Faust, Vol. I, pp. 188 ff.

18 Williamson, "History of North Carolina," Vol. II, p. 7r; Bernheim, "German Settlements and the Lutheran Church in the Carolinas" (1872), pp. I 50 f.; Faust, Vol. II, pp. 228, ff.

19 Vide, e. g., Roosevelt, "The Winning of the West," Vol. I, Chapter V, pp. 139 f. (Sagamore Edition). 
leys of York County were thrown open to settlers. Then in the late twenties and early thirties when proprietary restrictions and Indian claims were lifted west of the Susquehanna, they were moved by various considerations to dispose of their former lands and improvements and to begin life a second time on American soil by taking up lands on the inviting stretches of the newly opened county. It was this class of people, with several years of pioneer experience behind them, who constituted the great majority of the original German element in York County.

Some of the earliest settlers did, indeed, come directly from their landing-place and made our county their first American home, but such are comparatively rare instances. Of the known names of earliest settlers in the Kreutz Creek Valley and on Digges's Choice more than four fifths had arrived in this country before those settlements were begun and hence must have settled elsewhere before coming to York County. A search of the official lists ${ }^{20}$ of German immigrants reveals the fact that less than one fifth of those mentioned above (pp. $59 \mathrm{f}, 64,75 \mathrm{ff}$ ) are to be found among the arrivals from 1727 to 1740 . Nor does the identity of name always identify the person. Tobias Frey, Philip Ziegler, Nicholas Bucher, Nicholas Perie, Michael Miller, Caspar Spangler, and John Lehmann arrived in 1727. Peter Mittelkauf, Frederick Leader and John Morningstar arrived in $1728 .^{21}$ Jacob

20 Division of Public Records, Pennsylvania State Library, Harrisburg. Vide Rupp's “Thirty Thousand Names.”

21 Peter Mittelkauf is known to have settled first in Montgomery County, as did also Michael Will (Wüll) who arrived in 1732. Vide supra, p. 76 . Johannes Morgenstern's name occurs as late as June, I734, on the baptismal register of Pastor Stoever's Record for the Lutheran Church of the Trappe in Montgomery County. Vide "Proceedings of the Pennsylvania German Society," Vol. VI, pp. I78, I79 and I80. 


\section{I16 German Element in York County, Pa.}

Krebell and Christian Croll arrived in I 729. John Counts and Henry Smith arrived in 1730. All of these had arrived before the German migration across the Susquehanna had begun. Hence they must first have settled elsewhere in Pennsylvania. But Jacob Welshover, Henry Bann and Martin Schultz arrived in I73 I and may have gone directly to York County. Likewise the following: Martin Weigle, Martin Bower, Adam Miller (arrived I 732), Hans Steinman ( I733), Ulrich Whistler ( I733), Jacob Huntzecker (I733), Michael Spangler (I737), Martin Buyers (I738), and William Oler (I737). Matthias Ulrich arrived in $173^{8}$ but from his deposition of August 29, I 746, it is evident that he did not settle on Digges's Choice until $\mathrm{I} 742$, just before making his visit to Germany. ${ }^{22}$ Peter Ensminger arrived in Philadelphia in 1733 but first settled in Lancaster County where he was naturalized in $\mathrm{r} 734$ or $1735^{23}$ It is clear, therefore, that at all times the great mass of the immigrants into our county used some other part of Pennsylvania as a stepping-stone. ${ }^{24}$

Some few may have come from Maryland but the number of those who came from that direction could not at any time have been very considerable. It is known, for example, that in $\mathrm{I}_{7} 6_{5}$ Richard MacAllister sold several of his town lots to "George Naes, tanner, of Baltimore town, in the province of Maryland," and that after that the Nace family resided in Hanover ${ }^{25}$ The road on the

22 Archives, I: 700.

23 Rupp's "Thirty Thousand Names," p. 436.

24 In the statement of the Germans of August $1_{3}, \mathbf{I}_{73} 6$, they say: "being many of us then newly arrived in America," Col. Rec., IV: 64. But in the light of the above facts this expression cannot be taken to preclude several years residence in this country. It simply serves to explain their lack of acquaintance with political conditions ("altogether strangers to the boundaries") and accounts for their susceptibility to "plausible pretences."

25 Lucy Forney Bittinger's “The Forney Family, r690-r893," p. 59. 
line of the present Hanover and Baltimore turnpike had been laid out by order of the Baltimore County Court as early as $1736 .{ }^{26}$ This highway early established direct communication between Baltimore and the Conewago settlements. But there is no evidence to indicate that such transfers of German residence from Baltimore to York County took place earlier than that of George Naes in I 765 or that they were at all frequent even at so late a date as I765. The same is true of the Germans in the Kreutz Creek Settlement. The Germans whom Cressap placed on the improvements of those whom he succeeded in expelling from the west side of the Susquehanna had not been brought from Maryland. They were in all probability impecunious Pennsylvania German squatters from York or Lancaster County whom Cressap and his agents had seduced by fair promises. For in all the negotiations concerning the border difficulties between the provinces the distinction is sharply drawn between "the Marylanders" and "the Germans." The Maryland authorities assume that the Germans before settling west of the Susquehanna had been within the proper bounds of Pennsylvania, they protest against the action of the Pennsylvania authorities in securing the sworn allegiance of the Germans to the province of Pennsylvania immediately upon their arrival at Philadelphia, and they never claim, as they certainly would have done if there had been the least semblance of support for the claim, that the Germans had come from Maryland before taking up lands on the controverted territory. Everywhere the assumption

${ }^{26}$ According to a statement in a petition of the Conewago citizens of 1766 asking that the northern ten miles of the road be viewed and recorded in Pennsylvania. This petition is quoted in Gibson's "History of York County," p. 322. 
is that the Germans in that settlement had come from Pennsylvania. ${ }^{27}$

It would seem that as a class the settlers on the Codorus and about the future site of York had less American experience when they came to our county than those in the other German settlements. They had come more directly from the Fatherland. An unusual proportion of those gathered together by Pastor Stoever in 1733 had arrived in America after September, 1727. At least two thirds of the original members of that congregation were recent arrivals ( 5 of them had arrived in 1727 , I in 1729,5 in $173 \mathrm{I}$, and 6 in 1732 ) while in the other settlements, as we have seen, less than one fifth of the whole number had come after 1727. And this settlement continued to draw more extensively from the newest arrivals than the other settlements. For of the roo names of males entered in Stoever's baptismal register before I74I at least 49 had come to America since September, I727 ( 5 in 1727 , $\mathrm{I}$ in $1728, \mathrm{I}$ in 1730 , 10 in $173 \mathrm{I}, 23$ in 1732,6 in 1733 , 2 in 1734 , and I in I737). It is safe to conclude, therefore, that as a class the German settlers in the central part of the county had not tarried so long after landing in America before they came hither. But even they did not, except in a very few instances, come to York County directly from the port of landing. When the town of York was founded the earliest lot-owners came from among the Germans already living in the county. ${ }^{28}$ In the course of its growth and until it became a county-seat the town

27 Colonial Records, IV: $\mathrm{I}_{32}$ and 142.

28 Among the names of the first applicants for lots (p. $90 \mathrm{f}$ ) those of Baltzer Spangler, Michael Swope, Christian Croll, George Swope, Jacob Grebell, and Henry Hendricks are familiar to us as the names of early residents in the Kreutz Creek Valley. 
continued to draw its citizens from the outlying districts of the county and from Lancaster County. After the progress of the earliest settlements was well under way and after the border difficulties were adjusted it occurred more frequently than earlier that Germans settled in York County immediately upon their landing on our shores. We have one striking instance of this in the case of Lorentz Schmal. He arrived in Philadelphia on September 2, I743, and went at once to take up a farm at what is now Maish's Mills, six miles southeast of York, where he became the progenitor of the numerous and influential Smalls of the county. ${ }^{29}$ But up to the middle of the century when Yorktown began to attract attention, this class of settlers directly from the Fatherland formed no considerable part of the community.

The great majority of the German settlers in York County came from the fertile lands of Lancaster County just across the Susquehanna. This was the chief source of recruits and reinforcements for the York County settlements but it was not the only source. Some of them came, as we have seen, from Philadelphia and Philadelphia County. Such was the case with Adam Forney, the conspicuous pioneer among the Germans on Digges's Choice, who had been living in Philadelphia County fully ten years before he removed to the southwestern part of York County. ${ }^{30}$ Such also was the case with George Albright and his son Anthony, who had settled in Philadelphia upon their arrival from the Palatinate and had remained there some eight years or more before taking up lands in the valley of the Codorus near the newly founded town of

29 "Genealogical Records of George Small, etc.," p. 4.

30 Vide supra, p. 73 . 
York. $^{31}$ Some of the immigrants into York County came from the banks of the Schuylkill in Montgomery County. Such was the case with Andrew Schreiber, also one of the earliest settlers on Digges's Choice, who had been settled at Goshenhoppen near the Trappe for nearly thirteen years before he took up his abode near Christ Church. His brother Ludwig, their stepbrother David Young, Peter Mittelkauf, and Michael Will also came from Montgomery County. ${ }^{32}$ The Tulpehocken settlements in Berks and Lebanon Counties also made their contribution to the valleys of the Codorus and the Conewago.

But while these counties along the course of the Schuylkill sent of their valued citizens to strengthen the settlements of York County, yet their combined total output to that county was not nearly so great as that of the single county of Lancaster on the Susquehanna. As the eastern counties furnished the first settlers for Digges's Choice and the Conewago, so Lancaster County furnished the first settlers for the Kreutz Creek and Codorus Valleys. And the indications are that throughout the first three decades of the history of these settlements the greater number of the Germans on the Conewago in the southwestern part of the county came from the more remote regions of the Tulpehocken, the Schuylkill, and the Perkiomen, while the vast mass of those in the valley of the Kreutz Creek came from the nearby lands of the Conestoga and the Pequea. ${ }^{33}$

When the German settlements in York County began Lancaster County was already well settled. Hundreds of

31 "Genealogical Records of George Small, Philip Albright, Johann Daniel Dünckel, etc.," pp. 99 f.

32 Vide supra, pp. 75 .

${ }^{33} \mathrm{Of}$ many of these it is definitely stated that they formerly resided in Lancaster County. 
Swiss Mennonites had settled in the western part of the county in I710 and for several decades thereafter their brethren in the faith, both in Switzerland and along the Rhine, made Lancaster County their objective when they decided to forsake their European homes. Then people of other religious persuasions who were persecuted on account of their faith, Lutherans and Reformeds, joined the stream to Lancaster County. Its picturesque seclusion made it appeal also to that class of religionists who were given to extreme pietism and a semi-weird mysticism. The reputation of its fertile soil made it specially attractive to people who must needs devote themselves to agriculture. ${ }^{34}$ All of these factors helped to swell the procession of Germans from the port of Philadelphia to the fertile soil of Lancaster County. Thus in course of time this county came to be known as the chief gathering-place of Germans in the province, the location of "the great body" of them, and hence most of the newcomers in those early decades began their experience in America by "repairing to the great body of their countrymen settled in the county of Lancaster on the east side of the Susquehanna." 35 The York County Germans were simply doing what "many others had done before" them when they set out for Lancaster County immediately upon their arrival in America.

What the causes were that led the German people to

34 George Ford's MSS., quoted in Rupp's "History of Lancaster County," p. II5, says: "Their success, the glowing, yet by no means exaggerated accounts given by them, of the scenery of the country, the fertility of the soil they cultivated, the abundance of game with which the forest teemed, the quantity and delicacy of the fish which the rivers yielded; but above all, the kind and amicable relationship they cultivated and maintained with their Indian neighbors, all conspired to make them the objects of attention, and afterwards one of the prominent points whither immigration tended in an increasing and continued stream."

35 See the statement of the Germans quoted above pp. $97 \mathrm{f}$.

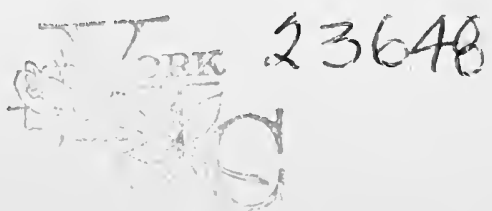


cross the Susquehanna River into the bounds of York County they themselves imply in their statement that "they found the lands there [i.e., east of the River] generally taken up and possessed and therefore... went over the River." It was not because of political oppression or unsatisfactory religious conditions such as had moved them to leave the Palatinate. It was not because of dire economic necessity, such as had impelled the Germans of New York to leave the Mohawk Valley and settle in the Lebanon Valley, Pennsylvania. It was not race prejudice such as helped to determine the movements of the early ScotchIrish in America. It was not the love of adventure, such as operated in the settlement of Ohio. Nor was it the desire for great financial gain through speculation in lands, such as contributed to the German settlement of the Shenandoah Valley of Virginia. But it was simply the next and most natural step in the expansion of the population in the search of the most comfortable means of subsistence and the most convenient soil upon which to invest their meager savings and fix their humble dwellings. The continuous stream of German farmers into the territory just east of the Susquehanna had occupied the best and most convenient farming districts there and in the third decade of the century many of those who had settled there found themselves crowded and'so sold their lands and improvements to their neighbors or to newcomers and moved on to where lands were more plentiful and convenient. ${ }^{36}$ It was a short step across the Susquehanna. ${ }^{37}$ The soil promised

36 "Dahero gehen sie immer weiter fort in das wilde Gebüsche. Solche die ... aus Noth weiter fortgehen müssen in die noch ungebauten Einöden, schreiben bisweilen die beweglichsten Briefe, sie erzählen wie gut sie es gehabt." H. M. Muhlenberg in his Hallesche Nachrichten, I: 342.

37 As the Susquehanna could not be forded, ferries were established at 
well. Fathers saw better prospects there for securing lands for their growing sons. They had spent several years in the New World and had become accustomed to the pioneer life. The period of stress in their history was passed and they were now in a better position to endure the struggle with the untamed forests than they would have been immediately after their arrival in the country. And above all the persuasions and inducements held out to them by the proprietary agents who wished to preëmpt the soil west of the river under Pennsylvania authority, helped to encourage them in their expansion and furnished the immediate occasion for it.

Such was the combination of immediate causes that brought the Germans to the Kreutz Creek Settlement. And very similar must have been the motives of those who settled Digges's Choice. There is evidence that these settlers in the southwestern part of the county also had gathered somewhat of possessions in the way of farming implements and equipment before emigrating from their former abodes, so that they too had some experience and were not the raw and unprepared victims of pioneer conditions. It is worthy of note also that in the case of these settlers on Digges's Choice we must count as a contributory cause, in addition to the causes mentioned above, the personal work of John Digges through his soliciting agents.

an early date. The earliest and most important of these was John Wright's Ferry, chartered in 1730 . It crossed the river at the point where the road from Lancaster and the Monocacy Road afterwards met the river. Wright's Ferry was established to meet the needs of intending settlers in York County. But once established it also helped to give direction to subsequent immigration into those parts by providing the only convenient crossing-place. For more than a century it was part of the great highway from Philadelphia to the West. In $18 \mathrm{r}_{4}$ it was converted into the Columbia bridge. 


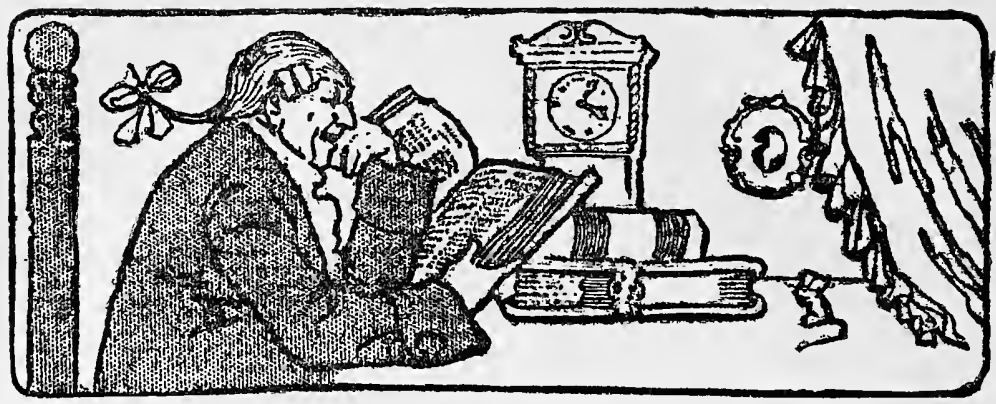

CHAPTER VI.

\section{Outstanding Characteristics.}

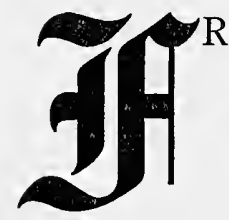

ROM the foregoing account of the steps in the movements of the Germans from the time they left their native land until they reached York County, it must be evident that the original element in our county had two outstanding characteristics, namely, that by occupation they were almost exclusively farmers, and that in character they were hardy, aggressive and self-reliant. Both of these characteristics serve to indicate the distinctive relation of the German element in York County to the general movement of Germans in this country and help to determine their distinctive contribution to American civilization.

The resoluteness and independence of spirit which characterized the York County Germans from the very beginning distinguishes them from most of the other German settlements in America at the time of their beginnings. For as a rule the German pioneers in this country had fled from their homes and had reached our shores under circumstances that left them broken in spirit, practically destitute of means, satisfied with a mere livelihood, and not at all disposed to resist the injustice of the authorities or the 
impositions of their neighbors. Neither their class nor their condition permitted them to make any immediate contribution to the stream of American civilization.

The very earliest settlement, that of Germantown, had, it is true, manifested a high degree of aggressiveness and self-confidence and had attracted the respectful attention of all the other colonists. But that was due not only to the more favorable conditions under which these settlers had emigrated but also to the fact that the members of this closed German community on the banks of the Delaware enjoyed the personal acquaintance and the special favor of the great founder of Pennsylvania, who was their brother in the faith and who had been their companion in persecution. Moreover, for a whole generation this settlement had the great benefit of the leadership of the learned and distinguished Pastorius. For these reasons the inhabitants of Germantown were able to begin at once and to maintain throughout a flourishing German civilization and at the same time compel the esteem and respect of their Englishspeaking neighbors.

But quite different was the experience of the other German settlements in America. The thousands of Palatines who came to New York in I 7 Io were not the bold, selfreliant souls who go forth in search of religious freedom, else their history in New York might have been very different from what it was. Rather were they the pitiable victims of economic bankruptcy, fleeing from their homes in search of the necessaries of life. They were willing and able to work and some years later, when they could make the opportunity, they proved themselves to be really expert farmers. But when they first arrived in this country, through no fault of their own they were placed. in 
circumstances that precluded the free exercise of their agricultural talents and compelled them to engage in an ungrateful task and one to which they were not at all adapted. Their unhappy past had filled them with infinite patience and endurance and had made them all too willing to be led and ruled, though they were without leaders and rulers among their own ranks. Even before crossing the ocean they had become the objects of English scorn. For when in I709 some I4,000 of these economic fugitives from the Palatinate and from Würtemberg flocked aimlessly into London, their destitute condition aroused the pity of the English and even of the visiting Indian chiefs, and out of commiseration for the "poor miserable Germans" a camp was provided for them on Black Heath where as the objects of charity they were kept from starvation during the winter. And when in the spring they were sent by thousands to Ireland and to the American colonies, 3,00o of them were dispatched to New York. Those who survived the horrors of transportation across the ocean were driven into veritable slavery on the banks of the Hudson and set to work under government overseers to make tar for the English navy. This colony the English settlers had once entered on their own initiative and with high and hopeful mien. The German immigrants now came to it as hirelings, almost as slaves, humbled and bent, led by taskmasters and under the paternal direction of the government even in the details of their lives. With great humility and with a deep sense of their inferiority to their English masters, as faithful "bounden servants of His Majesty," they drew out their weary lives and constantly measured their strength against poverty and want. Flight from the valley of the Hudson availed them 
little, for the English authorities pursued them to the valleys of the Schoharie and the Mohawk and there continued to embitter their lives. But the constant dangers of life in the wilderness developed among them men of leadership like the Weisers, strong spirits capable of breaking the net that had been thrown over them. And when after two decades of American bondage the New York Germans finally gained the right to hold their lands with a sense of security and to enjoy the fruits of their labors, they swung themselves higher and steadily higher to positions of useful and independent citizenship and in the course of time took their places alongside of the best in their province. Their early misfortunes had only delayed the inevitable development of their German culture on American soil.

The German settlements in Pennsylvania, east of the Susquehanna, had preliminaries far less dismal than those antecedent to the German settlements in New York. The conditions under which the Pennsylvania Germans came to our country were not nearly so hopeless for the future, the circumstances under which they settled in the new country were not nearly so humiliating nor so compromising of their personal dignity, as was the case with their countrymen in the neighboring province to the north. Nevertheless the early Germans in eastern Pennsylvania were characterized by great modesty and reserve. They asked only to be left alone. They had no desire to impress themselves upon their neighbors. They seemed to stand in awe of their more numerous and more aggressive English neighbors. Theirs was not the cringing attitude of those who are reduced to dire economic necessity. They were for the most part religious refugees fleeing before 
the oppression of intolerant rulers and seeking their inalienable right of freedom to worship God. They devoted themselves diligently to their work and to their worship. But they led a quiet, unobtrusive life, yielding a passive obedience as citizens but allowing others to have charge of public affairs, living at peace with all men and preferring to yield every point rather than to become involved in strife. Their entire bearing in those early years of their life in the New World was not the bearing of aggressive American citizens but that of a people who, for the time at least, seemed to regard themselves as strangers in an Englishman's country.

This attitude of apathy, this lack of aggression on the part of the Germans when they arrived in southeastern Pennsylvania, was not due entirely to the quietistic principles of their religion. It is to be explained also on the ground that the English in those parts could claim priority of settlement and great preponderance of numbers. The English had determined the language of the province and the Germans were regarded as "foreigners" in the land even after they had taken up their abodes in due legal form. The first generation of newcomers naturally did not learn to speak English and this made them the objects of connivance and suspicion not only on the part of their English-speaking neighbors but also on the part of the proprietary authorities. Even the Quaker Assemblymen were persuaded to enact special legislation in the case of these Germans, because they felt that such special measures were necessary to secure the allegiance of the Germans to the British King and to the proprietors of Pennsylvania. ${ }^{1}$ After submitting to such measures the Ger-

1 On September I4, I727, Governor Gordon called a special meeting of the council to report that large numbers of Palatines were arriving from 
mans in those early decades of their American life could not but feel that they were guests in the English colony and that their presence there was largely by sufferance of the English authorities.

Another reason for the unequal position of the Germans among the English in southeastern Pennsylvania during the first half of the eighteenth century is to be found in the extreme poverty in which most of them arrived in this country. Most of the German emigrants had not the means to pay their ocean passage. They were persuaded therefore by the agents of the ship-owners to take transportation on the basis of a contract binding them to a certain period of service (usually from five to seven years) after they should arrive in America. On reaching America these contracts were offered at public sale by the ship-. owners and the scenes enacted at the port of landing were often pathetic and revolting and always humiliating to the German colonists in America. Those who thus sold themselves into service were known as "redemptioners." Their fate usually amounted to practical slavery. ${ }^{2}$ Comparatively very few of this class of immigrants came from any other country than from Germany. Another class of German immigrants, but less numerous than the redemptioners,

Holland and advised them that "it would be highly necessary to concert proper measures for the peace and security of the province, which may be endangered by such numbers of Strangers daily poured in, who being ignorant of our Language \& Laws, and settling in a body together, make, as it were, a distinct people from his Majesties Subjects." One week later the Council approved the oath of allegiance which all of "those Palatines" arriving thereafter were required to sign. Col. Rec., III: $282 \mathrm{f}$.

2 The revolting experiences of the redemptioners, both on shipboard and after their arrival in America, are vividly portrayed by Gottlieb Mittelberger in his "Reise nach Pennsylvanien in Jahre I7'50" and "Rückreise nach Deutchland im Jahre 1754" (Stuttgart, 1756) and by Heinrich Melchior Mühlenberg in Die Hallesche Nachrichten, page 997. 


\section{I30 German Element in York County, $\mathrm{Pa}$.}

had sold all of their possessions to pay for their transportation. Arriving in this country penniless they would make their way through the inhabited parts of the land, begging as they went, until they reached the borders of civilization where they would settle as squatters. ${ }^{3}$ This made a very unfavorable impression upon the early inhabitants of English blood, who enjoyed the utmost personal freedom and a satisfying abundance of this world's goods and who in addition were well provided with leaders. This moving picture of time-serving and povertystricken Germans, in groups and in companies, an army without officers, ${ }^{4}$ greatly reduced the favorable impression that had been made by the Germantown community under Pastorius. Their resigned attitude and the utter helplessness of their position gradually brought the Germans into the contempt of their English lawgivers and in every measurement they were placed at least one degree lower than those who spoke English. When they finally brought themselves into positions of prominence and equal influence with the English they did so against great odds.

These facts just related furnish the necessary perspective in which to view the York County Germans if we wish to determine their place in the general history of Germans of America and in the development of our national character. For, to this inferior standing of the earliest Germans among their neighbors in their original settlements in New York and in eastern Pennsylvania, the German

3 It is from these conditions that Charles Sealsfield has drawn his doleful picture of the early Germans in his voluminous works on America and Americans.

4 Friedrich Kapp in his "Geschichte der Deutschen im Staate New York bis zum Anfange des I9. Jahrhunderts" has said: "Zur Eroberung des neuen Weltteils stellten die Romanen Offiziere ohne Heer, die Deutschen ein Heer ohne Offiziere, die Engländer dagegen ein Heer mit Offizieren." 
settlement of York County presents a striking contrast. It marks a new step, one of the first in the Americanization of the Germans in this country. ${ }^{5}$ In the settlement of York County we have a stage in the political and cultural evolution of the Germans in our country that was not attained in other German communities until the middle of the eighteenth century or until the Revolutionary War. The first generation in this county occupied a position and influence and manifested an aggressiveness of character that was only attained by the second or even the third generation of their countrymen east of the river. From the beginning of their history York County affairs received their color and their trend from the German element in the county, and from the beginning, too, German customs and peculiarities have shown great tenacity here.

The Germans who first settled in York County belonged to that hardy class of individuals who are not afraid to venture forth even in the face of danger. When they came to this county they placed the broad Susquehanna between themselves and the great body of their countrymen and in many instances they separated themselves by wide stretches of wilderness from the habitations of civilized man. Men of daring and men of brawn they were, determined to stand on their rights and to resist any encroachments upon their liberties. Nearly all of them had spent several years upon American soil and were now beginning life anew. Their experience had been valuable. They had become acclimated to America and inured to the soil of the New World. They had passed the period of strain and stress which always came to every immigrant when he first arrived. Though by no means rich, they had

5 It was paralleled perhaps by the case of those New York Germans who had fled to the Lebanon Valley. 
passed beyond straitened circumstances and had usually accumulated enough to provide their own equipment and a fair degree of comfort. They had not been preceded west of the river by a large number of English-speaking neighbors who could thus lord it over them. The settlements of the English in the northern part of the county and those of the Scotch-Irish in the southeastern part had begun almost simultaneously with their own, certainly not earlier, and these settlements had not grown nearly so rapidly as their own. The Germans were able therefore to make York County predominantly a German county and their life manifested an independence of spirit and a self-reliance that was quite unknown in the incipient stages of other German settlements.

This view is amply substantiated by a scrutiny of their conduct during the early years of their settlement in York County. The difficulties occasioned by the border controversy between the two provinces concerning the lands in the Kreutz Creek Valley furnished abundant opportunity to show the mettle of the Germans who had settled there. They had been invited into those parts as a buffer against the intrusion of Marylanders and they served this purpose well. Their tenacity of purpose and their stout resistance was a matter of no little surprise to those who sought to intrude upon their domain. It cost them many conflicts and not a few real hardships but under the capable leadership of men like Michael Tanner, Henry Hendricks, Christian Croll, and Henry Liphart, they succeeded in maintaining themselves and preserving their allegiance to Pennsylvania until the exact determination of the boundary line settled the whole difficulty. Some of their number had been persuaded or forced to acknowledge the 
authority of Maryland for a while but they were quick to observe that the Maryland government discriminated against them in its dealings with its subjects, and their resentment at this, together with other arguments of reason, ${ }^{6}$ led them fearlessly to disown the authority of Maryland, to refuse payment of taxes to Maryland agents, and to prepare to stand their ground as citizens of Pennsylvania. In their statements to the governor of Maryland they give unmistakable evidence of their fortitude and determination. In their communication to him under date of August I I, I736, they protest against being "seduced and made use of, to answer purposes which are unjustifiable." 7 And in a subsequent reply to the governor they firmly declare themselves unwilling to tolerate the "impositions" of the Maryland agents and "the uncommon and cruel usage" to which they had been subjected. They recount their reasons for concluding "upon their own observations" that they are within the rightful bounds of the province of Pennsylvania, and then register an emphatic refusal to act "against the manifest convictions of our consciences." Later they explain their action on the ground that "we believed in our consciences it was our duty." For freedom of conscience they had come to America and

6 Among these other considerations which weighed with the Germans to convince them that they were within the proper bounds of Pennsylvania was the fact that the Maryland government persistently failed to give them certificates or warrants for their lands, the observation that their own countrymen east of the river were settled may miles farther south than they themselves and had been settled there for twenty-five years under the undisputed jurisdiction of Pennsylvania, and the conclusion that it was impossible for the Susquehanna to be the boundary between the provinces. Col. Rec., IV: 493 .

7 Md. Archives, Vol. 28I: roo f.; also Col. Rec. Pa., IV: 6I f.

8 Col. Rec., IV: 492 f.

${ }^{\circ}$ Col. Rec., IV : 75 . 
freedom of conscience they are now determined to maintain in York County though it be necessary to fight for it. They were accused of having revolted from their allegiance to Maryland because of the influence and persuasion of the agents of Pennsylvania. This they deny very emphatically. They stoutly insist that they have acted solely upon their own initiative and in a special statement they set forth at length that they have taken these measures entirely "of our own mere motion and freewill, without any previous persuasion, threatening or compulsion." ${ }^{10}$ And this there is every reason to believe. It was always doubted by the Maryland authorities, but it is substantiated both by direct statements and, what is more, by the clearest of implications on the part of the Pennsylvania authorities. ${ }^{11}$

10 Ibid.

11 The full and confidential statement of Blunston gives no intimation that he has persuaded them to this action but plainly implies that they have taken the initiative in the matter (Col. Rec., IV: 57), and the personal appeal of the Germans in Philadelphia (Col. Rec., IV: I8:8 f.) shows their sincerity in their move. Furthermore the unmistakeable implications of several private letters from Blunston allow no reasonable doubt that the Germans proceeded without his instigation. Already on January 2, 1735, almost eighteen months before the Germans actually transferred their allegiance to Pennsylvania, Blunston wrote to the proprietary: "A few days since twelve or fourteen Dutch Inhabitants on the other side opposite to us were here and desired to be admitted to take licence under you. They think they have been imposed upon by the Marylanders and most of Em incline to be Pennsylvanians." Afterwards during the difficulties that followed upon the "revolt of the Germans" there arose between Blunston and Penn a slight difference of opinion as to the policy that ought to be pursued and on January $\mathbf{I}_{3}, \mathbf{I}_{737}$, Blunston wrote to Penn protesting that Penn's letters implied a conviction "that he receiving the Dutch as tenants to this government (who bad once been under that of Maryland) was an act of favor to them and not a benefit to your proprietary interest. . . Now if that be the case I must acknowledge the principles 1 have acted on have been wrong, for when the Dutch informed me of their inclinations to change I believed it would be for your benefit." This clearly indicates that the Germans had taken the initiative, for if Blunston had tried to 
The action of the Germans in refusing to pay taxes to Maryland and in declaring themselves citizens of Pennsylvania called forth retaliatory measures from the Marylanders. They sought to collect taxes from them by force. They harassed and plundered them and threatened them with fire and ejectment. The Germans used peaceful means of defence as long as that course seemed feasible. On one occasion when the Marylanders were seizing the goods of some of the Germans "under pretence of publick Dues" the Germans sent Michael Tanner to remonstrate with them. He went alone and met them "six miles back from the River" and by reasoning with them succeeded in getting them to withdraw under a truce of two weeks. ${ }^{12}$

In the hope of adjusting the difficulties without resorting to force they sent to the Council at Philadelphia and asked that their tracts be laid out in accurate surveys so that they might have clear titles under Pennsylvania. ${ }^{13}$ Later they proposed to go in a body to Annapolis and lay their case before the Governor in person, acquainting him with the violence and the inconveniences to which they were exposed by "Higginbotham and his lawless crew," and seeking his intervention for the betterment of their conditions. ${ }^{14}$ And they even took measures to apply to the King himself for the redress of their grievances. ${ }^{15}$ But neither of these latter proposals seem to have been carried into execution.

persuade them to disown Maryland and to acknowledge Pennsylvania he would certainly have used this fact as an argument here in this confidential letter. And Penn evidently knew nothing of such efforts to persuade the Germans and even doubted the expediency of receiving them when they had applied.

12 Col. Rec., IV: 69; also a Blunston letter to Penn of Sept. 8, 1736.

${ }^{13}$ Col. Rec., IV: 70.

14 Col. Rec., IV: 155 .

15 Col. Rec., IV: 156. 
I36 German Element in York County, Pa.

The Germans sought first of all to keep the peace so long as that was possible without doing violence to their consciences, but when peaceful measures did not avail and when they were threatened with attack they did not scruple to employ more strenuous measures of defense. ${ }^{16}$ When the governor of Maryland threatens to treat them like rebels and enemies they prepare to defend their homes. They meet force with force. When unable to do this alone they call for constables and assistance from the other side of the river. When Cressap captures one of these constables and is hurrying off with him towards Maryland he is "warmly pursued" and the constable is rescued.17 When the outrages of the Marylanders continue without abatement they send a delegation of their number to Philadelphia with representations to the provincial council concerning their distresses and praying for aid against the turbulent enemy. ${ }^{18}$ When a force of 300 comes from Maryland the provincial government of Pennsylvania takes a hand in the defense but not without the valiant aid of the Germans themselves. ${ }^{19}$

By the beginning of 1737 several of their leaders had been taken captive and the guerilla tactics of the Marylanders had so depleted the numbers of the Germans that the rest of them became terrified and fled across the Susquehanna for safety. ${ }^{20}$ In May, $\mathbf{1} 737$, many of them are reported in prison at Annapolis. ${ }^{21}$ But meanwhile their stout resistance west of the Susquehanna had permitted the cumbersome negotiations between the two provinces

\footnotetext{
16 Col. Rec., IV: 148.

17 Col. Rec., IV : 58.

$18 \mathrm{Col}$. Rec., IV: $188 \mathrm{f}$.

${ }^{19} \mathrm{Col}$. Rec., IV: 63 ff.

20 Col. Rec., IV: 149 .

21 Vide supra, p. 68 , footnote 39.
} 
and between the proprietors in England to take their course without prejudice to Pennsylvania and their service to their state had been rendered even though they were now for a time driven from the field. Another year saw the royal order of 1738 and its temporary conditions afterwards led to the permanent jurisdiction of Pennsylvania over all that disputed region.

The Germans were always encouraged by the Lancaster County authorities and by the provincial council of Pennsylvania ${ }^{22}$ and their firm unyielding attitude was appreciated by those authorities. The council sympathized with the Germans in the hardships and distresses to which they were exposed but at the same time they felt that for the Germans to yield to their adversaries and quit their habitations west of the Susquehanna would mean the overthrow of an important principle and might involve serious consequences for the future of the province of Pennsylvania. For when Samuel Blunston raises the question before the council "whether it may be more elegible to order the Removal of all those who are seated under Pennsylvania on the west side of Susquehanna, than to use further Endeavours for their Defence, since it is now apparent these cannot be effectual without coming to Blows," the council sets itself strongly against the suggestion, on the ground that "it is not consistent either with the Honour or Safety of this Province, to remove those of its Inhabitants who are seated within its unquestionable Bounds, since such an Act might be construed a Cession of those parts to Maryland, who would not fail thereupon to take possession of them; and in all probability from such an Encouragement, would endeavour at further Encroachments on this side of the River, in pursuance of their late

22 E. g., Archives, I: 317 ; ; Col. Rec., IV : 195. 
exorbitant Claims."23 It was felt that the honor and authority of the province depended upon the tenacity of the German settlers. ${ }^{24}$ This responsibility they discharged by insisting upon recognizing the jurisdiction of Pennsylvania until the crisis of the controversy between the provinces was passed. This function they performed for the history of Pennsylvania not so much out of a consciousness of their mission as out of their native hardiness and aggressiveness of spirit. And these qualities of character were a source of no little gratification to the provincial authorities. For, says James Logan, President of the Council, in a writing to Governor Ogle dated September I 8,1736 , in which he speaks of the encroachments and the hostilities west of the river: "This province, especially those parts are filled with people of more spirit than to brook such treatment, and if any mischief ensue on their opposition to your attacks, you cannot but well know who must be accountable for it." ${ }^{25}$ Where the poverty-stricken

${ }^{23}$ Col. Rec., IV: r.5o f.

${ }^{24}$ Blunston wrote to the proprietary on October 17,1734 , suggesting that the tracts of the Germans be laid out to them and that they be given surveys, and observing: "Tis true the setlers are at present generally poor and unable to pay for their lands (or even the surveys) but we look on them as persons suitable to keep possession." The sentiments of this letter were endorsed by John Wright. The Lancaster County officials evidently appreciated the resoluteness and tenacity of these Germans, and two years later when the forceful conflicts west of the river have begun and when Thomas Penn suggests that some of the Germans be removed, Blunston sets himself against the suggestion and remarks (letter received by Penn on December I, 1736): "For those who are most in danger by staying are those who are most resolute and active and by whom the rest are directed." The York County Germans evidently did not lack aggressive leaders among their own numbers.

${ }^{25}$ Col. Rec., IV: 78. This sentiment concerning the "spirit" of the Germans was echoed a few months later by the governor and council of Maryland in a communication to the King dated February 18, 1737, in which they say the government of Pennsylvania "was pleased to issue a 
squatters would not have ventured in the first place, where the enslaved redemptioners could not have gone, where the Germans of New York would have been compelled to flee, and where the peaceful Mennonites east of the Susquehanna because of their religious convictions would have refused to resort to force, the Germans of York County firmly stood their ground in the maintenance of their rights and in following the dictates of their consciences. Their independence and aggressiveness of spirit is therefore of no small importance in the history of their county and state and in the history of German Americans in general.

Similar qualities of character and disposition are found in prominence also among the early German settlers on Digges's Choice. This is evident from the account of the beginnings of that settlement as given in Chapter IV. ${ }^{26}$ These settlers had ventured farther out on the frontier, but in many respects their fortunes, as we have seen, paralleled those of their countrymen in the eastern part of the county. A few references will suffice to indicate the same unquenchable spirit of independence and the same unwillingness to endure imposition.

With keen discernment they conclude from Digges's conduct in refusing to survey the bounds of his tract and from inconsistencies in his utterances, that he cannot make

proclamation under the specious color of preserving peace, but really to inflame and incite the inhabitants of those borders (which that government then acknowledged was filled with people of more than ordinary spirit) to the commission of horrid and cruel violences."

The Lancaster County authorities had had occasion to test this spirit of the Germans. For during the short time that they had acknowledged the jurisdiction of Maryland the German settlers did not scruple to resist the Lancaster County officers when they felt they were being imposed upon. See, for example, the incident of the rescue of John Lochman from Sheriff Buchanan, supra, p. 56; also Col. Rec., IV : 194.

${ }^{26}$ Vide supra, pp. $69-85$, for the facts referred to here. 
good all of his claims. They coolly plan to have his bounds surveyed on their own account, and this determination they carry into effect despite Digges's opposition. When it thus becomes clear that they had been imposed upon, they proceed to take out warrants under Pennsylvania. Then when their lands are still claimed by Digges under a resurvey, they petition the Pennsylvania authorities for advice how to proceed. ${ }^{27}$ A warning from the secretary of the province does not deter Digges from trying to force some of the Germans to pay him for their lands. Then they meet force with force, and drive off the officers that try to carry them to Maryland. They express in no uncertain terms their determination to stand on their defense and to insist upon their rights. ${ }^{28}$ Several times they make petition for authoritative adjustment of matters, on the ground that they do not wish to be put in the position of resisting government but that they cannot tolerate the abuses which are being practiced on them. ${ }^{29}$ And several instances are on record of strenuous resistance to what they regarded as the injustice of Digges. The dealings of Adam Forney with the Maryland officers and the shooting of Dudley Digges may serve as examples of the tenacity of these Germans in maintaining their rights. Thus they manifest much the same stern qualities of character which their countrymen in the Kreutz Creek Valley manifested, though, of course, with less vital consequences for the future of the province.

27 Archives, I: 680 f. and 683. "The people hope that Your Honor [i.e., the governor] will direct inquiries to me made into the true state of this matter and give them your directions for their behavior with Mr. Digges." 28 Vide supra, p. $83 \mathrm{f}$.

29 "For we are no people that are willing to Resist government, but rather to semit, if we do but know how, and whare; and further Beg you would advise us how to behave most safely in the main Time." Archives, I: 724. 
Another characteristic of the early Germans in York County is worthy of note in this connection. It was one that they shared with all of the early Germans in this country with the possible exception of the Germantown settlement. Theywere at a great disadvantage, both socially and politically, because they could not speak the English language. For while the provincial authorities of Maryland recognized the Germans of our county as a resolute, determined people whose resistance it was almost impossible for them to break, and while the provincial authorities of Pennsylvania recognized those hardy Germans as a very fit element with which to withstand the encroachments of the Marylanders, nevertheless there is unmistakable evidence that on both sides of the line those who made the laws and enforced them looked down upon these Germans with a certain degree of contempt and disdain. The records of the unhappy incidents growing out of the boundary dispute between the provinces indicate very clearly that the spirit of nativism was already at work in that early day and that the Germans were regarded as "ignorant and unfortunate Dutchman," the helpless victims of circumstances and suitable objects for the commiseration of their English-speaking superiors.

In a deposition of December 2, I736, John Starr relates an interview that he had with the governor of Maryland a few months previous in the course of which "the Governor said that there were some Unfortunate Dutch Men that had lately Apply'd themselves to him for those Lands, $\&$ that he went there \& Settled them, \& and that he condoled the Misfortune of the sd Dutch Men for declining to be Subject to the Government of Maryland, \& turning to the Proprietors of Pennsylvania, And that the sd Dutch 
142 German Element in York County, $\mathrm{Pa}$.

Men had Revolted through Ignorance or Perswasion, And that the Governor further said that if the sd Dutch Men did not Return again to the Government of Maryland he would not Suffer them to Live on those Lands any Longer. . . ."30 This was evidently the general attitude of the Marylanders towards the Germans. For ten days later Edmund Jennings and Daniel Dulaney, the two Maryland commissioners who had come to Philadelphia to treat with the Pennsylvania council concerning the troubles west of the Susquehanna, in the course of a lengthy communication to Logan and his council observe concerning the Germans: "they must certainly be ignorant Forreigners or they would never have been so far deluded as to imagine it to be in their power to divest the Lord Proprietary of Maryland of whom they received their possessions, of the Rents and Services due from them as Tenants." ${ }_{11}$ And in the communication of the Maryland authorities to the King on February I 8, I737, they declare that they have exercised " the utmost care to disabuse these deluded people," and that "this government might reasonably conclude these unfortunate people had been privately encouraged by some persons daring enough to protect them against any prosecution." 32

Much the same attitude of lofty superiority towards the Germans was held by their fellow-citizens in Lancaster and Philadelphia, though without the element of bitterness which naturally entered into the feelings of the Marylanders. When in August, I736, they decided to renounce the authority of Maryland in the Kreutz Creek

30 Archives, I: 509.

31 Col. Rec., IV: 132.

$32 \mathrm{Md}$. Archives, for 1736 . 
Valley and to acknowledge the jurisdiction of Pennsylvania in those parts, they sent several representatives to state their case to Samuel Blunston and to ask his advice. Shortly thereafter Blunston reported the matter in person to the provincial council at Philadelphia and in explanation of their conduct stated that they were "ignorant people who had been seduced, and now being sensible of it, were desirous to return and live under our proprietor who alone they believed could truly be their landlord." He said that he "told them, since it was their ignorance, and the false information of others, and not malice by which they had been misled, they need not doubt but they would be received and treated as the other inhabitants." 33 A few weeks later the Pennsylvania council in a letter to Governor Ogle of Maryland remarked concerning the "natural Honesty and Simplicity" of "those Palatines" and then added: "they have been made Sufferers by their Weakness and Credulity in believeing those busie Emissaries." 34 Repeatedly they are referred to by the council simply as "those poor people." 35 And on one occasion the council wrote of them as "those poor ignorant foreigners who had transported themselves from Germany into Pennsylvania." 36

In a petition to the King, dated December I I, I 736, the Pennsylvania council charged Cressap with having persuaded "some innocent German people lately come into Pennsylvania, who were ignorant of our Language and Constitution" to take possession of Lancaster County lands under Maryland jurisdiction, and in the same docu-

33 Col. Rec., IV : 57.

$34 \mathrm{Col}$. Rec., IV: 77 .

${ }^{35} E$. g., Col. Rec., IV : 114, 122.

36 Col. Rec., IV: 122. 
ment these Germans are referred to as "the miserable people." 37

It would appear then that the "misfortunes" of these "poor Dutchmen" were due primarily to their "ignorance" (they themselves called it "want of better information") and this in turn was due to their lack of familiarity with the English language. ${ }^{38}$ This ignorance made them susceptible to plausible pretences and the objects of wilful machinations. Their ignorance of the language of the government had led the government authorities to take special precautions to secure their allegiance. Hence the oath of allegiance to which they were obliged to subscribe upon landing at the port of Philadelphia. When in the course of the negotiations concerning the difficulties in the Kreutz Creek Valley the Maryland commissioners protested against these previous "engagements of Fidelity to the Proprietor of Pennsylvania" 39 the Council of Pennsylvania made reply:

The Germans who yearly arrive here in great numbers, wholly ignorant of the English Language \& Constitution, are obliged, on

37 Col. Rec., I26 f.

${ }^{38}$ In all their negotiations with the authorities in those first few years of their settlement in York County, their leader and spokesman was Michael Tanner. He was a young man, had been associated with the English at Parnell's in 1728 , and certainly was better acquainted with the language of the government than most of his countrymen. This quality alone was sufficient to make him one of their chief leaders.

The Germans as a rule employed an interpreter in their dealings with the authorities. As late as 1747 before the Provincial Council in Philadelphia, "Nicholas Perie desired that as he was a German \& did not understand the English Language, that he might be permitted to speak by an interpreter" and received the assistance of "Mr. Christian Grasshold, who is usually employed in this Service by the Germans." The "incivility of his Language" was excused on the ground that "it was owing to his Ignorance of the English Language." Col. Rec., V: 218. f.

39 Col. Rec., IV: 132 . 
Account of our too near northern Neighbors, the French, whose Language many of them understand, not only to swear Allegiance to our Sovereign, but as a farther Tie upon them they promised Fidelity to our Proprietors \& this Government, a Practice only used with them $\&$ no others. ${ }^{40}$

Their chief offense therefore seems to have been in the fact that they could not speak English immediately upon their arrival from Germany, and that some of them knew somewhat of French.

Very similar was the attitude towards the Germans in the southwestern part of the county. In 1747, when Adam Forney was arrested on Digges's Choice by a Baltimore County sheriff, ${ }^{41}$ the correspondence indicates that the secretary of Pennsylvania, Richard Peters, after a personal examination of Forney, is not a little fearful that the witnesses who will attend the Annapolis court will be unable to make themselves understood. $\mathrm{He}$ writes to Thomas Cookson, surveyor of Lancaster County, that the witnesses who are to accompany Forney to his trial must be able to testify "in a clear, positive manner, and therefore they must be sensible people, and people who know Digges' tract well, and Adam Furney's house, and can give a satisfactory account of things, so that the Court may understand them. I must, therefore, beg of you to attend Adam Furney in finding out such persons, and examine them yourself and be satisfied that they will answer the purpose effectually by giving a plain evidence." ${ }_{42}$ The difficulty, it would seem, was to get persons as witnesses who would be able to speak English well enough to be understood in Maryland. For, a few days

$40 \mathrm{Col}$. Rec., IV: $1 / 38$.

41 Supra, page 83 .

42 Archives, I: 728 . 


\section{I46 German Element in York County, Pa.}

later Cookson replies to Peters that he has now had opportunity to examine certain citizens from Forney's general neighborhood. "They are clear, intelligible men, and speak English well." This leads Cookson to a different conclusion from that which had been reached upon examining Forney himself. ${ }^{43}$ Whereupon Peters writes to Annapolis and dismisses the counsel he had retained for Forney's case and says: "Mr. Cookson had examination of some sensible people in Furney's neighborhood." 44 The inference is that Forney was not sensible, clear or intelligent. This was because of his lack of facility with the English language, a fact that is very manifest from his own letter to Cookson on this occasion. ${ }^{45}$ This correspondence, therefore, is one instance of several which show that the Germans were often regarded by the government officials and by their English-speaking neighbors as unintelligent and unreasonable, simply because they were unskilled in English.

The Governor of Maryland had thought that "the Dutch Men had revolted through Ignorance or Perswasion." But the clear logical arguments which they put forth in support of their action, and their emphatic disavowal of outside persuasion, showed that they were not so ignorant or so easily persuaded as the governor had supposed. And the subsequent determination of the boundary by the highest authorities completely vindicated them in this action. The governor had spoken of them as "unfortunate Dutch Men" whose misfortunes he con-

43 "Let Adam Forney defend his own Cause, since he has entirely misrepresented the situation of the place where he was arrested." Archives, I: 73 I.

44 Ibid.

45 Archives, I: 725 . 
doled. But the decision of conduct and the tenacity of purpose which they manifested in the course of the controversy, as well as the outcome of the whole difficulty, showed that his commiseration was quite superfluous.

The conditions imposed upon them by their pioneer life and their critical position in the conflict between the two provinces, together with the fact that they did not as a class speak the language of the governments under which they lived, naturally tended to diminish the respect in which they were held by those in the distance who were more comfortably established. But their "natural honesty and simplicity" and the fortitude and hardiness which they manifested in their difficult circumstances did not fail of appreciation, and those who knew these Germans well did not regard them as helpless creatures and objects of pity. For in their own county they have from the beginning been the most important single racial factor, politically, socially, and industrially.

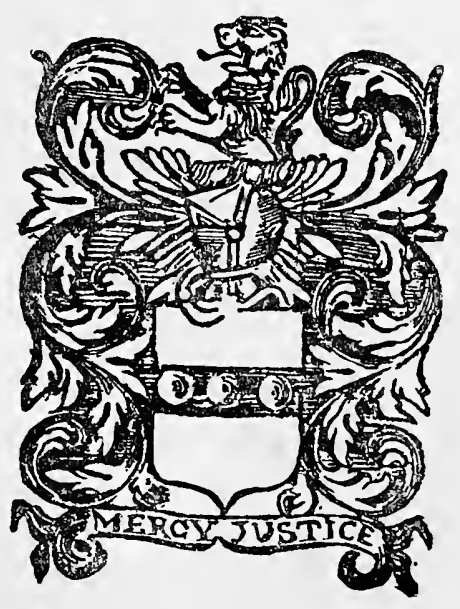




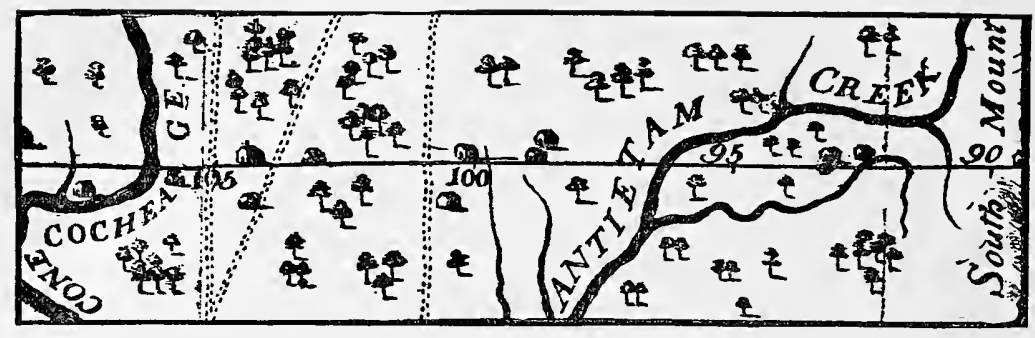

\section{CHAPTER VII.}

The Limestone Soil.

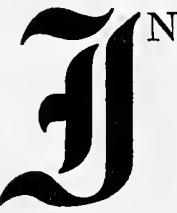

setting forth the original settlement of the primitive soil in this country and the subsequent readjustment of communities the effort is not infrequently made to show a relation between the preponderating nationality of a given settlement and the geological formation of its soil. The attempt has sometimes been made to indicate that such a general relationship applies to the German farmers of the eighteenth century. Thus it has occasionally been asserted in a general way that the Germans who came to this country before the Revolution regularly settled on limestone soil. Professor Faust says that when we study on a map the location of the Germans in America before the Revolution we are impressed with the fact that "the Germans were in possession of most of the best land for farming purposes. They had cultivated the great limestone areas reaching from northeast to southwest, the most fertile land in the colonies. The middle sections of Pennsylvania were in their possession, those which became the granaries of the colonies in the coming Revolutionary: War, and subsequently the foundation of the financial' 
prosperity of the new nation."1 This tendency to settle' a particular kind of soil, he says, was manifest among the' Germans in other colonies as well as in Pennsylvania; "They continued to settle in limestone areas in every new. territory, as for instance in Kentucky, where they entered the Blue-Grass Region in very large numbers during and immediately after the Revolutionary War. It is an interesting experiment to examine the geological maps of the counties in Pennsylvania where there were both German: and Irish settlers, such as Berks or Lancaster counties. The Germans are most numerous where the limestone appears, while the Irish are settled on the slate formations. This phenomenon is repeated so often that it might create the impression that the early settlers had some knowledge. of geology."2

Professor F. J. Turner is a little more specific when he says: "The limestone areas in a geological map of Pennsylvania would serve as a map of the German settlements. First they filled the Limestone Island adjacent to Philadelphia, in Lancaster and Berks counties; then they crossed the Blue Ridge into the Great Valley, floored with limestone. This valley is marked by the cities of Easton, Bethlehem, Allentown, Reading, Harrisburg, etc. Following it towards the southwest along the trough between the hills, they crossed the Potomac into Central Maryland and by 1732 following the same formation they began to occupy the Shenandoah Valley in Virginia."3 "The

1 "The German Element in the United States," Vol. I, p. 26.5.

2 Ibid., Vol. II, p. 34.

3 "Studies of American Immigration," by Frederick Jackson Turner, in the Record-Herald's "Current Topics Club," Record-Herald, Chicago, August 28 and September 4, rgor, "German Immigration in the Colonial Period." Cited in Faust, Vol. I, p. 138 . 
limestone farms of the [Pennsylvania] Germans became the wheat granaries of the country." 4

Another keen observer of conditions among the Pennsylvania Germans, Professor Oscar Kuhns, testifies to this same general fact. "The best soil in Pennsylvania for farming purposes is limestone, and it is a significant fact that almost every acre of this soil is in possession of German farmers. . . . It is due to the fact that Lancaster County is especially rich in limestone soil and is largely inhabited by Mennonites that it has become the richest farming county in the United States." 5 This author also cites in this connection the statement of the late Eckley B: Coxe that a letter from Bethlehem written to his grandfather asserts that in Pennsylvania, if you are on limestone soil, you can open your mouth in the Pennsylvania Dutch dialect and you will always be understood. ${ }^{6}$

Still another writer points out this same general fact and shows its effect upon the Lutheran Church in the United States. Dr. Sylvanus Stall in an article on "The Relation of the Lutheran Church in the United States to the Limestone Districts," shows how the Germans who

4 Faust, Vol. II, p. 34 .

5 "German and Swiss Settlements of Pennsylvania," p. $86 \mathrm{f}$.

6 Sometimes this observation that the Germans followed certain natural features of the country is expressed in terms of timber rather than in terms of soil. Then the comment is that the Germans selected districts that are heavily wooded. Mrs. Kate Asaphine Everest Levi, in "How Wisconsin Came by Its Large German Element" (1892), p. I7, says: "Thus the Germans are seen to be massed in the eastern and north central counties, a position that corresponds markedly with that of the heavilywooded districts; they have shown their preference first for the wooded lands near the main routes to travel, namely the eastern counties, and from there have spread to the north central parts of the State into the deeper forests."

${ }^{7}$ Lutheran Quarterly, Vol. XIII, I883, pp. $509 \mathrm{ff}$. 
had been placed at Newburgh on the west bank of the Hudson in 1708 were dissatisfied with the soil there and gradually migrated to the limestone districts of that state. $\mathrm{He}$ also shows how the Palatine refugees whom the English government had located on the east bank of the Hudson in I 710 , speedily removed to the Schoharie and Mohawk valleys with their clear water and their limestone rock. "When the migrations of this colony of Germans who constituted the beginnings of the Lutheran Church in the state of New York are followed, it will be found that when they moved in any considerable numbers their eventual settlement was upon the choicest lands, and when uncontrolled by foreign circumstances, it was upon limestone bottom. The same is true in Pennsylvania.... These tendencies of the earlier immigrants are to be found not only in Lancaster County, but are clearly defined in the broad limestone belt which sweeps across the State, including in its area the cities of Easton, Allentown, Reading, Lebanon, Lancaster, York and Harrisburg. The influences may alike be followed in Ohio, Illinois, Indiana and other States, and may account in a large measure for the absence of Lutheran congregations in New England."

Now these general statements concerning the preferences of the Germans for the limestone soil have never been verified by more exact determination. They are, however, confirmed in a remarkable way by the location and distribution of the Germans in York County. A study, of the German settlements in this county in their relation to the geology of the county and in their relation to other nationalities, reveals the fact that ethnologically York County is an epitome of the country at large. The relations of the Germans in our county serve to bear out the 
general observations noted above concerning the Germans in other parts of Pennsylvania and in other states of the union.

The geological map of York County furnishes an interesting analogy to the geological map of the whole United States. ${ }^{8}$ Each of the five great areas of geological time has its representatives within the borders of our county and they occur in much the same order and the same manner of contact in which they occur in the country at large. We have in this small compass parts of the ocean bottoms that were formed during each of the five geological ages. The general trend of the formations is from northeast to southwest. They are, in a general way, the continuation of the geological plains of Lancaster County and in their turn they merge into the formations in Adams County and Maryland. A brief survey of the geology and topography of the county is necessary to an understanding of the early German settlements in their relation to the soil and to other nationalities.

The oldest part of the county belongs to the Eozoic period. It constitutes a broad belt in the southern part of the county. Its southeastern boundary is on a line with the last course of the Muddy Creek. Its northwestern boundary lies approximately on a line beginning at the southeastern extremity of Lower Windsor Township ex-

8 Professor Persifor Frazer (professor of chemistry, Franklin Institute, Philadelphia) who supervised the Second U. S. Geological Survey of York County, says, "In a rough and general way, York County is a partial imitation, on a very small scale, of the United States; inasmuch as, like that part of the American continent, it consists of a belt of Archæan rocks in the northwest, of another in the southeast, and its intermediate portions are made up of newer formations containing fossils." And this analogy he carries into great detail. Vide Gibson's "History of York County," p. 463. 
tending thence westward, passing north of Windsor Post Office and then due southwestward between Dallastown and Red Lion, through the center of Glen Rock and north of Black Rock. It thus includes all of Upper Chanceford, Lower Chanceford, Hopewell, Fawn and Shrewsbury Townships, the western part of Peach Bottom Township, and parts of Windsor, Lower Windsor, Springfield, Codorus and Manheim Townships. This part of the county constitutes the geological floor upon which the other parts were laid.

These Eozoic rocks are destitute of valuable minerals in York County but the soil formed from them is comparatively fertile, second only to the fertility of the limestone soil. Its composition is generally slaty. It is capable of sustaining heavy timber growths and contains at present large woods of strong trees. When the earliest settlers came to the county there were large tracts in the southeastern part that were bare of all timber. This is accounted for by the Indian custom of burning the trees and other vegetation in certain sections either for the purpose of increasing the facilities of hunting or to provide land for the cultivation of beans and corn. ${ }^{9}$ This Eozoic belt of the county has received in history the uncomplimentary title of "The Barrens." This was not due to the character of the soil but to the absence of trees in the early days and to the methods of agriculture afterwards employed there. ${ }^{10}$ The earliest settlers who took up their abodes on

${ }^{9}$ Carter and Glossbrenner say that this was done to provide hunting grounds, but it seems more probable that these bare spaces in York County may be accounted for by the general observation of William Penn, "There are also many open places that have been old Indian fields." In a letter written to the Duke of Ormunde in 1683 , quoted from Egle's "Notes and Queries" by Swank, "Progressive Pennsylvania," p. 76.

${ }^{10}$ Philemon Lloyd says in his letter of October 8, 1722, "But from the 
this belt were unskilled in the art of agriculture and in the proper rotation of crops. They would select a tract of land and put out their crops but by unwise methods of culture would soon drain the soil of its substance. When one tract was exhausted they would desert it and move on to new tracts. Thus in the course of time there came to be a number of tracts in this region that were deserted on account of their sterility. Thus was perpetuated the name of "Barrens," a name that is quite at variance with the present flourishing condition of the soil brought about by the importation of wiser methods of cultivation. ${ }^{11}$

The next oldest geological formation in the county is found just north of the Eozoic belt. This belongs to the Cambrian period of the Paleozoic era. It is only about three fourths as wide as the Eozoic belt, but stretching as it does across the central part of the county it has a much greater length than the older belt and embraces a larger area in the county. Its northern boundary begins at the southern mouth of the Conewago Creek and extends with

Heads of Patapsco, Gunpowder, \& Bush Rivers, over to Monockasey is a Vast Body of Barrens; that is, what is called so, because there is no wood upon it, besides Vast Quantities of Rockey Barrens." Calvert Papers, No. 2, p. 56.

11 Christoph Daniel Ebeling in his "Erdbeschreibung und Geschichte von America," Vol. 4, r797, p. 68r, speaking of York County, says, "Das Land ist ziemlich angebaut, und man rechnete vor einigen Jahren schon, dass an drei Viertel desselben von Pflanzern besezt waren. Allein ihre Besitzungen sind lange nicht alle urbar gemacht, sondern viele davon noch mit dicken Waldungen besezt. Jedoch treiben viele, sonderlich die Deutschen, guten Kornbau, haben grosse Obstgärten mit Aepfeln, Pfirsichen, etc. und weitläufige Wiesen mit Timotheusgras etc., zum Theil auch etwas Kleebau. Hopfengärten giebt es gleichfals hie und da. Die Ackerpferde, welche hier fallen, werden wegen ihrer Stärke und Grösse geschätzt." These efficient methods of the Germans afterwards spread to other nationalities in the County and helped to abolish the wasteful conditions and inefficient methods of which Ebeling writes. 
much irregularity in a general southwesterly direction to Abbotstown just beyond the Adams County line. It thus embraces the whole of Hellam, Spring Garden, North Codorus, Heidelberg, Penn, and West Manheim Townships, and most of Manchester, West Manchester, Jackson, Paradise, Lower Windsor, Windsor, York, Springfield, Codorus, and Manheim Townships. It also includes Conewago and Union Townships in the southeastern part of Adams County. This kind of rock is also found on the southern side of the Eozoic floor and covers a large part of Peach Bottom Township. ${ }^{12}$

This Cambrian belt consists of four fairly distinct layers of rocks. The oldest of these are the chlorite schists, composing about one third of the entire belt and stretching along the southern portion of the area. Next in order is the Hellam quartzite, found chiefly in the township of that name but with outcroppings at many other places in this belt. Then come the hydro-mica schists, or limestone schists as they are sometimes called. These occupy in general the central and northern portion of the belt and encase the fourth and most recent layer which is the narrow ribbon of limestone stretching across the entire length of the Cambrian belt.

The presence of the Hellam quartzite lends an undulating effect to the landscape here. For the quartzite is very hard and enduring in composition. It undergoes but little decomposition either through chemical or mechanical action. Thus the less durable rocks, the argillites and the

12 This rock in the southeastern extremity of our county is the source of the celebrated Peach Bottom roofing slate. This economic value of the Cambrian rock as found in this Township grows out of the fact that it occurs there with a fine grain, an even texture, and an almost perfect cleavage. 
I56 German Element in York County, $\mathrm{Pa}$.

calcites, are disintegrated and carried away, leaving the quartzite outstanding in the form of hills. But the most important part of the Cambrian belt, so far as the history of the county is concerned, is the limestone formation. This is but a continuation west of the Susquehanna of that limestone formation which constitutes the major portion of Lancaster County. It is a comparatively narrow strip and extends continuously across the center of the county and into the southeastern corner of Adams County. The tract embracing the pure limestone soil is not more than two miles wide on an average, though at a few points it reaches a width of four miles. It begins at the mouth of the Kreutz Creek on the Susquehanna and extends along the whole length of that creek from the town of Wrightsville to the city of York. From York there is a narrow extension northeastward along the Codorus to its mouth, and one directly west among the sources of the Little Conewago. But the general direction of the limestone strip continues from York southwestward up the valley of the West Branch of the Codorus Creek and including Hanover, McSherrystown and Littlestown. An isolated tract of this formation also occurs at the mouth of Cabin Branch in Lower Windsor Township.

This limestone is a dolomitic composition containing varying amounts of carbonate of magnesia. It is popularly known as the "York limestone." Some of it is so hard as to furnish excellent building material. But most of it decomposes and mingles with the soil. Thus it has produced the most fertile soil in the county and, together with the related soil that was formed from the neighboring schists, it constitutes the richest farming area in the county, not unlike that of Lancaster County east of the river. It 
is well watered and the rolling contour of the ground makes it exceptionally well adapted to agricultural purposes. When the first settlers came to the county these limestone hills and valleys were covered with heavy timber, and under wise methods of culture the soil has continued highly productive ever since, and this belt has always been the scene of the county's chief industry and activity.

A third main geological division of York County embraces practically the entire northern part of the county. This belongs to the Triassic period of the Mesozoic era. It is very sharply defined from the Cambrian belt just south of it. It is that same red sandstone formation which begins in the extreme northern part of Lancaster County and covers nearly all of Adams County on the west. The line of demarcation from the Paleozoic era is quite clear and distinct because there are no traces whatever of the Silurian, the Devonian, or the Carboniferous periods of that era. The soil of this region differs widely from that of the other parts of the county. It is composed primarily of beds of red shale, red sandstone, and quartzite conglomerate. Extensive areas of trap also occur, and this is practically identical with the so-called "Gettysburg Granite" in Adams County. This material offers strong resistance to disintegrating forces and this has produced a number of elevated ridges and hills in this part of the county. It is also the geological cause of the bothersome falls in the Susquehanna near York Haven. Everywhere traces of iron abound, and it is this that gives the soil of the region its characteristically red color. On the rocks in this region occasionally occur deceptive stains of green and blue carbonates of copper. These were doubtless the cause of those nervous and illusive searches, surveys, and 
mining shafts, made by Sir William Keith and the Maryland adventurers in the hope of obtaining copper or some other valuable metal. There are many evidences of brownstone in this Triassic region of somewhat the same quality as the celebrated Hummelstown variety, but it has not yet been discovered west of the river in sufficient quantities to give it commercial value. Farming has always been the chief industry in this part of the county as in the other parts, although from the above description of the geology it must be clear that the soil here is not nearly so well adapted to agriculture as in other parts of the county. ${ }^{13}$

These are the three main geological divisions of our county. If now we examine the nationality of the earliest settlers in the county we find that they are three in number and that each one of them gravitated strongly towards one of the three general kinds of soil furnished by the geological divisions. Germans, Scotch-Irish, and English crossed the Susquehanna in rapid succession and settled within the limits of York County in the fourth and fifth decades of the eighteenth century. Of these the Scotch-Irish took up their abodes on the Eozoic belt in the southeastern part of the county where the ground required little clearing and where the soil was ready to produce at once. The Germans laid out their plantations on or near the limestone ribbon of the Cambrian belt in the central part of the county with its heavy timber, its rolling hills and its many streams. While the English Quakers chose to settle the Triassic region in the northeastern part of the county with its secluded lands, its red soil, and its mining prospects.

13 To complete our outline of the geolggy of the county it should be mentioned that the Cenozoic era is represented in the county principally by the marl bed north of Dillsburg in Carroll Township. Thus the great eras of geology are all present in some form or other. 
These choices were not promiscuous. But we are concerned here only to establish in detail the correctness of the statement concerning the Germans, and to indicate its probable causes and its results.

In the absence of individual surveys for the plantations of the earliest Germans in the county we are left to inference and general statements to show where they were. But these are so many and so varied as to permit a high degree of accuracy in locating the early German settlements upon the map. The very name of the Kreutz Creek Settlement indicates its general location. And the Kreutz Creek Valley, as we have seen, belongs entirely to the Cambrian belt and is composed almost exclusively of pure limestone soil. The pioneer plantation of this settlement was that of John Hendricks. He occupied a part of that I,200-acre tract which was marked off for the younger William Penn in July, I 727, and surveyed in November, I729. The whole tract is described in the warrant as "opposite to Hempfield," that is, due west of the town of Lancaster. Hendricks's part of this tract embraced 600 acres and it is described by the surveyor as "the uper side and best part of the tract." The lower part, $i . e$., the part nearest to the mouth of the Kreutz Creek, was occupied several years later by James Wright, son of John Wright. This embraced the landing-place of Wright's Ferry, the heart of the present town of Wrightsville. The entire tract therefore lay just north of the future "Monocacy Road,"14 the present turnpike from Wrightsville to York, and Hendricks's 6oo acres on the upper part of the tract was therefore but a short distance north of Wright's

${ }^{14}$ This road is described as beginning between the lands of James Wright and Samuel Tayler on the west bank of the Susquehanna immediately opposite the plantations of John Wright. Vide supra, p. 89. 
Ferry and embraced the plantation from which the squatter John Grist was compelled to remove in $1721 .{ }^{15}$ This is entirely within the limestone ribbon, as a reference to the geological map shows.

The other plantations in the Kreutz Creek Settlement are determined chiefly with reference to the Hendricks plantation. Michael Tanner, we have seen, was settled on a tract of 200 acres six miles southwest of John Hendricks. ${ }^{16}$ He had previously been seated for a short time near the mouth of Cabin Branch, which is also limestone soil, but from this location he was obliged to remove in I 728 together with several English squatters there. In I734, however, he took up his permanent abode on the limestone of the Kreutz Creek. Among his immediate neighbors were Conrad Strickler, Henry Bacon (Bann or Bahn), and Jacob Welshover. With these persons Tanner was engaged in burying another neighbor's child when they were all taken captive by the Marylanders. Another close neighbor of Tanner was John Lochman who said that his house was seven miles west of Hendricks, about two miles south of the "little Codorus" and within 100 yards of the main road through the valley. About one and one half miles east of Lochman along the main road lived the blacksmith, Peter Gardner. Farther east in the same limestone valley and on both sides of the road were the dwellings of Bernard Wiemar, Michael Reisher, Christian Croll, Francis Clapsaddle, Nicholas Kuhns,

15 The exact location of Grist's improvements is fixed by the two drafts mentioned, supra, p. 22. Blunston's letter of January 2, 1737 (Archives, I: ${ }^{\text {I9) }}$, says: "I suppose you know Hendrix's House stands just by John Wright's."

16 Vide supra, P. 57 , and Archives, I: 524 . 
Valentine Kroh, and Martin Schultz.17 Samuel Landis, the German shoemaker, had his shop on the Kreutz Creek. ${ }^{18}$ This valley was also the home of the other Germans in that first settlement. It is not possible now to locate precisely the individual claims of each one of the 50 or 60 German planters who settled in this part of the county before 1737 , but it is clear that they lay in the same general valley with those we have already fixed. For Michael Tanner in his solemn affirmation declares that in I 734 and I 735 Thomas Cressap "came into the neighborhood of this Affirmant and Surveyed upwards of forty tracts of Land for this Affirmants Countrymen, the Germans living in those Parts." ${ }_{19}$ This same idea is expressed or implied in a number of other depositions and documents relating to the border difficulties. The Germans who signed the papers to the governor of Maryland and to the council of Pennsylvania in August, I736, spoke of one another as "neighbors." Their place of assembling in self-defense was John Hendricks's house at the foot of their valley. They regularly referred to their individual plantations as lying southwest of John Hendricks. The Marylanders in their attacks upon the Germans never met any opposition nor found any victims until they had come into the immediate neighborhood of the Kreutz Creek,

17 Vide supra, p. 65. When John Powell, under-sheriff of Lancaster County, affirms that these men lived "on the West side of the Sasquehannah River, not above one Mile to the Southward of the house of John Hendricks" (Col. Rec., III: 6ri3), he evidently does not mean to say that they all lived within one mile's distance of Hendricks's house, but merely that they were within the undoubted bounds of Pennsylvania because they all lived north of a line passing east and west through a point one mile south of Hendricks's house. Thus they lived in the valley just north of the Kreutz Creek.

18 According to Carter and Glossbrenner, vide supra, p. 39.

19 Archives, I: 5215 . 
and they never proceeded farther north than that valley. The Springettsbury Manor, whose bounds were relocated in 1762 by means of the German plantations, lay wholly within the Cambrian belt spreading a short distance on each side of the limestone ribbon in the Kreutz Creek Valley. And at the judicial investigation in 1824 evidence was presented proving that in 1736 at least 52 Germans had settled on that area in a regular manner. There can be no doubt therefore that most of the original German settlers in the eastern part of the county were located on the pure limestone just north of the Kreutz Creek, that the rest of them were settled on the fertile soil of the adjacent limestone schists, and that practically all of them, if indeed we may not say all of them without exception, were seated within the Cambrian belt.

The same kind of soil continues to be the abode of the Germans as we follow their settlements westward across the county. The settlement which had gathered on the Codorus about the future site of York, ${ }^{20}$ occupied the limestone strip at its place of greatest breadth. Here the limestone valley of the Codorus meets the prolongation of the Kreutz Creek Valley and the combination produces an unusually favorable location for a flourishing farming community. This region therefore supports the densest population in the county and the original German settlement here flourished from the beginning.

Among the most prominent families in the early history of this settlement on the Codorus were the Spanglers. 'About I730 Caspar Spangler settled 7 I I acres about a mile and a half east of the Codorus and extending across the future Monocacy Road but lying chiefly north of that

20 Vide supra, p. 90. 
road. ${ }^{21}$ His brother Baltzer arrived in the community in ' 732 and took up 200 acres about a mile east of the Codorus somewhat to the south of Caspar's land about the spot where the present Plank Road intersects with the first run. ${ }^{22}$ Contiguous to this was the abode of Tobias Frey. About a mile north of Tobias Frey was the land of his father Martin Frey, who had settled there in I 734 and whose property is now embraced in the northeastern part of the city. ${ }^{23}$ Before 1738 , Caspar Spangler's sons, Jonas and Rudolph, settled upon a tract of 7 I 9 acres seven miles west of the Codorus "near the Little Conewago Creek on the Conogocheague Road," now the York and Gettysburg turnpike. This was a part of the westward extension of the limestone ribbon, which forms as it were an offshoot from the main southwestward direction, and which contains many of the large springs that supply the sources of the Conewago. Another settler in this community and "near Codorus Creek" was Frederick Ebert, whose lands were in 1736 possessed by Valentine Schultz. About three miles northwest of the present site of York

21 Edward W. Spangler, Esq., describes this land as follows: "seven hundred and eleven acres of limestone land about one and a half miles east of that portion of the banks of the 'Katores' on which Yorktown was thirteen years later laid out. The plantation began at the northern range of hills and extended across what was later designated as the 'Great Road leading from York-town to Lancaster.' . . . A deed for 385 acres thereof was executed by Thomas Penn to Caspar Spengler October 30 , 1736. . . . The southern portion, bisected by the 'Great Road,' was conducted by Caspar in conjunction with his youngest son Philip Caspar Spengler." "The Spengler Families with Local Historical Sketches," p. I8. 22 Ibid., p. 138 .

${ }^{23}$ This land was afterwards owned in turn by Isaac Rondebush (I74I), Michael Schwack (I74I), and Bartholemew Maul, the schoolmaster (I743). By 1750 Hermanus Bott, one of the earliest lot-owners in York, also possessed about 300 acres on the west bank of the Codorus adjoining the town on the northwest. Gibson, p. 5ir4. 
I64 German Element in York County, Pa.

lay the adjoining lands of Michael Walck and Martin Bauer, and about five miles southwest of the town were the properties of George and Jacob Ziegler. ${ }^{24}$ From this point the German plantations stretched off northeastward down the Codorus Valley and southwestward up the valley of the west branch of the Codorus, and these limestone bottoms were the main support of the town of York during its early years.

Precisely the same rule obtains with reference to the German settlements on Digges's Choice in the southwestern part of the county. This tract was chiefly limestone soil and it was settled chiefly by the Germans. From the definition of Digges's Choice already given ${ }^{25}$ and by reference to the geological maps of York and Adams Counties it will be observed that these 10,000 acres lay wholly within the Cambrian belt and almost wholly on the limestone ribbon, embracing all of its southwestern extremity. About six miles of the end of this strip was cut off from York County when Adams County was erected in 1800 , and thus a few of the original plantations now fall within the bounds of Adams County. But this fact only serves to impress upon the historian the regularity with which the Germans settled upon the limestone, for this southeastern extremity of Adams County is the only limestone soil in the whole county and to this day is the only German community in the county. The limestone ribbon across York County reaches a greater width on Digges's Choice, the present neighborhood of Hanover, than at any other point except where it crosses the Codorus, the present site of York. And the farms adjacent to

24 Vide Map $F$, Report of Secretary of Internal Affairs of Pennsylvania, 1905, Part I.

25 Supra, p. 70. 
Hanover are among the most beautiful and prosperous in the county.

Adam Forney, the first German settler in this settlement, located his claim on the present site of Hanover. Andrew Schreiber soon thereafter settled near what is now Christ Church, about four miles southwest of Hanover. This is also on pure limestone soil, though now in Adams County. The German neighbors of these two pioneers located on the fertile lands between them and just north of them. Digges's original survey of 6,822 acres extended four miles north of the temporary line of 1738 and included the present site of Hanover. His addition of 3,679 acres adjoined his original survey on its north side and was situated therefore wholly on the limestone formation, as a reference to the geological map will indicate. This inviting soil was the disputed land and on this area lay the plantations of most of those whom we have learned to know as the earliest settlers of Digges's Choice.

From the recorded incidents in the early history of this settlement it is clear that Adam Forney's land lay within Digges's original survey and just south of his addition, that Schreiber's land and that of his neighbors from Philadelphia County also lay within Digges's first survey and that Martin Kitzmiller, John Lemon, Nicholas Forney, Matthias Ulrich and practically all the other Germans whose names are mentioned in the course of the disturbances, were settled upon Digges's additional survey on soil contiguous to his original survey. Their location there was the reason why they were involved in disturbance and why their names are preserved for us. The Germans had been induced to begin their immigration into this community partly by the personal persuasions of Digges and 
his agents. But the location of their individual tracts they determined for themselves. They invariably located on the limestone bottom. Digges's misfortune, therefore, lay in the fact that he had not at once included in his original survey all the limestone soil in that neighborhood. For this German settlement on the Conewago would have been spared many years of strife and contention if the bounds of Digges's Choice had coincided throughout with the limestone belt.

There is therefore a remarkable coincidence between the location of the early German settlers in the county and the length and breadth of the limestone ribbon that runs across the county. In the few instances where the German plantations did not perhaps lie directly on the pure lime. stone soil, they coincided with the nearby limestone schists or hydro-micas, also a part of the Cambrian belt. From this the original home of the German element in York County it has since spread out over the entire Cambrian belt with its fertile soils related to limestone. And even on the isolated outcroppings of limestone rock near New Market in the extreme northern end of the county, and on the small district north of Dillsburg in Carroll Township, we have today the homes of German communities. A more striking illustration than York County affords of the tendency of German settlers to occupy limestone soil can probably nowhere be found.

English speculators took out large tracts of land in these valleys of our county but it was the Germans who settled them. The Englishman, Samuel Blunston, issued the licenses and English surveyors laid off the tracts, but German immigrants occupied them. Englishmen supervised the affairs of Yorktown but Germans were the lot-owners and the citizens. An Irishman held the claim to Digges's 
Choice but it was chiefly the Germans who settled the tract. Both English and Irish sought to establish themselves on the limestone island at the mouth of Cabin Branch south of the Kreutz Creek Valley, but in the course of time the Pennsylvania claim to that neighborhood prevailed and the limestone island was swallowed up and assimilated into the general German belt. On this kind of soil the Germans took up their abodes in the beginning, from this soil they excluded practically all representatives of other nationalities, and to this soil they have themselves clung most tenaciously to the present.

The frequent recurrence of this phenomenon in eastern Pennsylvania and the striking regularity and precision with which it occurs in York County encourages us to seek for its causes here. It appears then that the reasons for this rule of choice among the Germans in our county are two. In the first place, the Germans chose good farming land and in Pennsylvania the best soil for agriculture is limestone soil. It is highly improbable that the German immigrants had any knowledge or concern about the geological formations of the different districts. They had regard first of all to the vegetation which the different sections had produced in their natural state and they made choice of those regions where the trees were largest, the timber the thickest, and where the vegetation was most luxuriant. Then, too, the German insisted that his prospective farm must be well watered. These marks he always found on the acres that were underlaid with limestone.

The German instinct for the selection of good soil is traditional. It was soon observed by their neighbors in eastern Pennsylvania. The eminent Quaker, Dr. Benjamin Rush, the Tacitus of early Pennsylvania, has noted 
the fact in his classic pamphlet entitled "An Account of the Manners of the German Inhabitants of Pennsylvania." 26 Speaking of the German farmer he says: "They always prefer good land or that land on which there is a large quantity of meadow ground. From an attention to the cultivation of grass, they often double the value of an old farm in a few years, and grow rich on farms, on which their predecessors of whom they purchased them nearly starved." 27 This intuitive knowledge of good land and this agricultural success was the inheritance of thirty generations of ancestors. The crowded conditions of life in the Rhine Valley had led to very intensive methods of cultivation, a fine skill in agriculture, and the highest degree of wisdom in the husbanding both of soil and of crops. These qualities had made the Palatinate the "garden spot" of Germany, and transferred to the rich soil of eastern Pennsylvania they made it the pride of the Keystone State. ${ }^{28}$ The native tenacity and the indomitable

26 This essay was written in 1789 , edited and republished by I. D. Rupp in 18715 , and revised with a full introduction and copious annotations by Theodore E. Schmauk in 19ro. Dr. Schmauk's edition appeared as Part XXI of "Pennsylvania: The German Influence on its Settlement and Development" in the Proceedings of the Pennsylvania German Society, Vol. XIX. In his discerning account Dr. Rush gives many interesting details concerning the methods which the early Pennsylvania Germans employed in their farming and of the characteristics which distinguished them from other nationalities in Pennsylvania.

27 Pp. 56 f. Schmauk edition. Sydney George Fisher in his "The Making of Pennsylvania" gives a brief resume of Dr. Rush's observations on this subject. He puts it thus: "They [the Germans] were good judges of land, always selected the best, and were very fond of the limestone districts." But Dr. Rush made no mention whatever of "limestone" and there is no evidence that the Germans consciously and purposely sought out this particular geological formation. They were only looking for good land and if this could have been found on any other kind of rock they would have been attracted thither.

28 This inherited agricultural skill, together with the regular selection 
industry of the Germans, together with the hard conditions under which they left their native land, made them willing to undertake heroic tasks when they arrived in the New World. Undaunted by the size of the trees or the thickness of the wilderness they boldly attacked the forests, for they realized that where the heaviest timber grew the soil must be most capable of producing rich crops. This was undoubtedly the guiding principle that led the Germans to the limestone soil. Other nationalities such as the Scotch-Irish clung to the lands that were more easily cleared. They were less inured to heavy manual labor and were guided by their bucolic instincts, while the slowly plodding German looked farther into the future and was guided entirely by his sharper eye for good soil. ${ }^{29}$ Thus in Pennsylvania he invariably preferred the limestone regions and in York County this preference always placed him on or near the fertile ribbon that stretches along the central Cambrian belt.

After the Germans had begun their settlement in these

of good soil, made the limestone farms of the German farmers in Lancaster, York and the other German counties without a superior in this country. Their value to the State of Pennsylvania was early recognized by Governor Thomas who said to his council on January 2, 1739: "This Province has been for some years the Asylum of the distressed Protestants of the Palatinate, and other parts of Germany, and I believe it may with truth be said that the present flourishing condition of it is in a great measure owing to the Industry of those People; and should any discouragement divert them from coming hither, it may well be apprehended that the value of your Lands will fall, and your Advances to wealth be much slower; for it is not altogether the goodness of the Soil but the Number and Industry of the People that make a flourishing Country." Col. Rec., IV : 3 I 5.

${ }^{29} \mathrm{Dr}$. George Mays refers to this contrast between the German farmer and the Scotch-Irish farmer in a brief and popular article on "The Early Pennsylvania German Farmer" in the Pennsylvania German magazine, Vol. II, No. 4, October, Igor, pp. 184 f. Vide also Kuhns, "German and Swiss Settlements," p. 85, and Lutheran Quarterly, Vol. XIII, 1883, p. 509 f. 
fertile valleys other nationalities also began to recognize their value and in some instances looked upon them with covetous eyes. As early as I733, when Cressap and some of his associates were trying to fix their abodes and establish their claims upon the cleared limestone lands at the mouth of Cabin Branch, Governor Gordon of Pennsylvania wrote to Lord Baltimore, "I could not but be of opinion that as some Gentlemen of your Lordship's Province, who, casting an Eye on those Lands, now rendered more valuable by the Neighbourhood of our Inhabitants, had attempted so unjustifiable a Survey, it might suit their purposes to have Cressop and some others of the like turbulent Dispositions settled there, to give some Countenance to their claim." 30 Others recognized also the value of the arable lands in the Kreutz Creek Valley and were very willing to take charge of them after the Germans had cleared them with the heavy toil of years, had made improvements upon them, and had begun their cultivation. In the fall of 1736 , when the Germans, as we have seen, were already occupying many tracts west of the Susquehanna, and when the Chester County Plot was laid against their lands, the impelling motive of the plotters was to secure possession of the "good land" which the Germans occupied: This is indicated repeatedly by the affidavits concerning the incident. ${ }^{31}$ These efforts to seize the lands of the German are real compliments to his wis-

${ }^{30}$ Pennsylvania Archives, Fourth Series, Papers of the Governors, Vol. I: 505 .

31 For example, Henry Munday, one of those implicated in the plot, testified before the Pennsylvania Council on November 27, 1736, that he and others had met Cressap and "that Cressap had shown them some vacant Plantations, and Some that were inhabited by Dutch People, with a very large Tract of good Land." Col. Rec., IV: 107. This idea recurs frequently. 
dom in the choice of soil and to his skill in methods of clearing and cultivating. ${ }^{32}$

But there is also a second reason why the Germans in York County settled with such regularity upon the kind of land that they did. This is found in the general ethnological principle that when people migrate from one country to another, or even from one neighborhood to another, they tend to take up their new abodes upon land whose natural features resemble those of the abodes they have left. This tendency has often been observed and it has been evidenced by many nationalities. ${ }^{33}$ It applies notably to the many Scotch-Irish in Pennsylvania and it applies to the Germans. These early German immigrants into our state were chiefly Palatines. Their native land lay about the banks of the middle and upper Rhine. It included more than the present Bavarian Palatinate; it stretched across to the eastern side of the river and embraced parts

32 In 1744 Daniel Dulany of Annapolis made a trip to the more remote parts of his province, evidently the neighborhood of Digges's Choice, and upon his return wrote a letter to Lord Baltimore which indicates that he valued the limestone soil of that region.

"I have not been long returned from a journey into the back woods, as far as to the Temporary line between this province and Pennsylvania, where $I$ had the pleasure of seeing a most delightful Country, A Country my Lord, that equals (if it does not exceed) any in America for natural advantages, such as a rich \& fertile soil, well furnished with timber of all sorts abounding with limestone, and stone fit for building, good slate \& some marble, and to crown all, very healthy. The season of the year was so far advanced towards Winter that I could not possibly go to the neck of land in the fork of the Patomack. ..." Calvert Papers, No. 2, p. II6.

${ }^{33}$ Faust calls attention to it briefly thus: "This principle of selecting land similar to that which was found good at home prevailed even on a second and third choice. Remarkable instances have occurred in the cases of families who have migrated farther and farther westward, generation after generation, of the choice of a farm or homestead almost identical in appearance with the one owned by them in the original locality." Vol. II, p. 35 . 
of Hesse, Baden, and Würtemberg. From all parts of southwestern Germany they came. Now if we examine the topography of this part of Germany we find that it resembles closely the topography of the limestone districts of southeastern Pennsylvania including the Cambrian belt of York County. ${ }^{34}$

The geological formation of the Rhenish Palatinate and her nearest neighbors, it is true, is not limestone. The Bavarian Palatinate consists of four distinct sections measuring north and south, the level plain nearest the Rhine, the rolling hills which mark the approach to the Haardt, the wooded heights of the Haardt itself, and the foothills of the western district. Southwards all of these sections merge into the forests of the Vosges. The geologist discerns three geological groups, the alluvial deposits on the plain, the red sandstone soil of the rising hills, and the coal regions of the third section. In the countries just east of the Rhine the red shale of the Triassic period predominates again and lends the soil its chief characteristics. ${ }^{35}$ This part of Germany is not entirely without its

34 An understanding of the geology and topography of the Palatinate and southwestern Germany may best be gathered from the following works: W. H. Reihl, "Die Pfälzer," pp. I-69. E. von Seydlitz, "Handbuch der Geographie," 25th edition, pp. 4515-462. Cf. map of forests, p. 432. F. Ratzel, "Deutschland," pp. 23-132.

"Deutschland als Weltmacht," pp. 4-27, Chapter on "Deutsche Erde und Deutsches Volk," by Professor W. Goetz.

Franz Heiderich, "Länderkunde von Europa," pp. 94-II2.

35 Ratzel says: "Weit verbreitet sind von den nördlichen Vegesen an durch den nördlichen Schwarzwald, den Odenwald, Spessart, das hessische Bergland, Thüringen und das obere Wesergebeit die roten, oft leuchtend purpurbraunen Gesteine des Rotliegenden und des bunten Sandsteins, eine mächtige, aber einförmige Bildung, die dem Walde günstiger als dem Acker ist. In weiten Gebeiten Mittel- und Südwestdeutschlands breitet sich über Ackerland und Stadtarchitektur einen rötlichen Hauch. Von Basel bis Frankfurt sind die Münster und Dome aus rotem Sandstein gebaut." "Deutschland," p. 30. 
limestone but it is almost negligible in quantity and it is of that firm unyielding variety which only constitutes a barrier to the farmer. Thus the Rhenish province of Hesse contains a considerable region of durable limestone with a strong dolomitic admixture and a very narrow strip of this rock extends across the Rhine and southwards across most of the Palatinate, appearing here in the form of brecciated limestone conglomerate. So that nearly everywhere it is the Trias of the Mesozoic era which gives color to the soil. Geologically, therefore, it cannot be maintained that the Germans in our county settled upon the same kind of formation as that from which they had come when they left Europe. And herein lies a very strong indication that these people did not consciously seek out the limestone tracts when they settled in the New World.

But when we turn from the geology to the topography of the middle Rhine valleys and of southwestern Germany we find that it is very much like that of the districts upon which the German immigrants settled in York County. Not level like north Germany, not mountainous like south Germany, but a medium between the two, an undulating plain and easy rolling hills. The most familiar features in the configuration of the country are the gradual eminences which mark the steps in the elevation from the level of the Rhine in the center to the heights of the Haardt in the west and the Vosges in the southwest and to the Swabian Jura in the east and southeast. ${ }^{36}$ The numerous valleys between are well watered by the many streams that ultimately empty into the Rhine. The red soil of the Trias is not so well adapted to agriculture as some other

36 "Wellenförmige Fläche" and "Hügellandschaft" are the expressions most frequently used to describe the rolling surface of this country. 


\section{I74 German Element in York County, Pa.}

kinds of soil and in this part of Germany it required a hand that was highly skilled in agriculture to make the soil yield sustenance for its dense population. But this soil is well adapted to forest growths and to this day it contains large stretches of sturdy timber. Its dense forests with their luxuriant foliage constitute one of the most striking characteristics of the Palatine hills and indeed of southwestern Germany in general. From the Odenwald in the north they stretch to the Black Forest in the south and across the Rhine to the Vosges Forest in the west. In the seventeenth and eighteenth centuries this region must have been even more heavily wooded and it was only natural for the Palatines when they reached York County to welcome the sight of the thick timber growths on the central belt. The general contour of the Palatinate the Germans found reproduced in the undulating central region in York County with its rich forests and its many springs and streams. ${ }^{37}$ The unconscious charm of the homeland and an instinct for the best soil led them therefore to fix their abodes upon the limestone soil and begin the work of taming the wilderness. And this fact has had a marked significance in their subsequent fortunes in this county.

37 The writer can testify from personal observation to the striking similarity between the configuration of the land in the Rhenish Palatinate and that of the limestone valleys in York County.

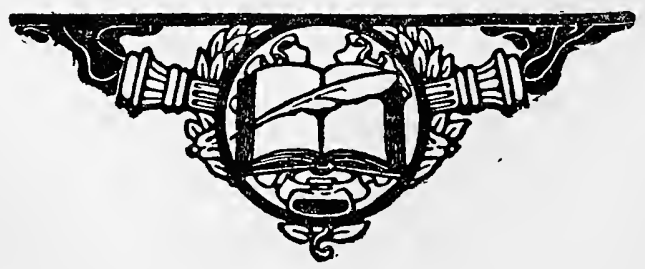




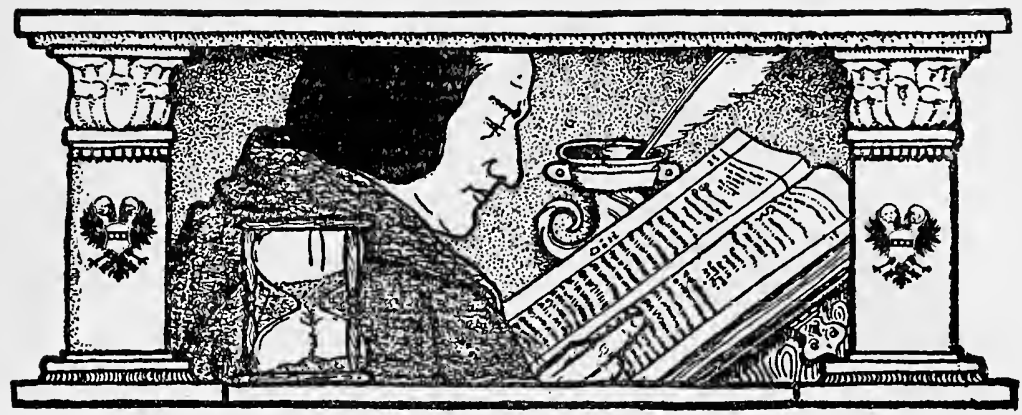

CHAPTER VIII.

\section{Their Place in Pennsylyania History.}

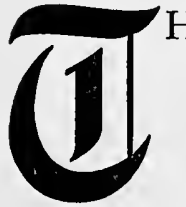

HE part which the York County Germans of that early period played in the history of colonial Pennsylvania and in the general course of American history may be gathered from the facts and events already narrated. They were a valuable support to the provincial authorities of Pennsylvania at a time when that important province was passing through its most formative period. The Germans of York County contributed in their small measure to the support and strength of the provincial government both in its conflicts with Maryland and in its contest with certain opposing elements among its own population. Then, too, these pioneer settlements stretching out into the primeval forest seem like an index finger pointing westward to an empire of land and wealth whose conquest and acquisition by successive steps of similar communities was to make the future greatness of our nation. And finally, these first German settlers in York County constituted a small but relatively important part of that numerous and growing body of farmers in our province who early got into the native soil and drew from 
it the materials that formed the basis for the prosperity of colonial Pennsylvania, even as today they constitute the backbone of the nation.

In the first place their significance for the political history of the province during those early years grows out of the fact that they were on friendly terms with the Quaker Assembly at Philadelphia. The province of Pennsylvania shared with New York the place of greatest prominence and importance among the middle colonies of the North American coast. Now the government of Pennsylvania, though at first apparently under the absolute control of one individual, was nevertheless in reality more completely democratic than any other in America. In this respect Penn's province presented a striking contrast to the government of the Puritans in New England, that of the Episcopalians in Virginia, and that of the Catholics in Maryland. Government in Pennsylvania was thoroughly representative. ${ }^{1}$ Other colonies, notably Massachusetts and Virginia, had enjoyed a fair degree of self-government at first but had later forfeited their privileges into the hands of tyranny. But the history of Pennsylvania before the Revolution is a continuous story of the unintermittent development of civil liberty. This contrast is due to the complete ascendancy of the Quakers in Pennsylvania during that long, formative period from 1682 to 1776 , when they suddenly disappeared from

1 This is only cited as one of the achievements of the Quakers in colonial Pennsylvania. Others may be gathered from Chapters IV-VII of Isaac Sharpless' "A Quaker Experiment in Government."

W. A. Wallace in a lecture before the Pennsylvania Historical Society in 18.82 on "Pennsylvania's Formative Influence upon Federal Institutions, I 682-1787" shows by a clear statement of actual facts what remarkable results colonial Pennsylvania achieved for the nation. Vide also Pennypacker, "Pennsylvania in American History," pp. $202 \mathrm{ff}$. 
power. Until the middle of the eighteenth century the political history of Pennsylvania is a history of the Quakers and from I 755 to the Revolution it is a history of the unsuccessful efforts on the part of the Scotch-Irish and the Church of England people to displace the Quakers. Throughout the period of their ascendancy the Quakers were warmly supported by the numerous German element in the province. ${ }^{2}$ For the Germans never forgot the debt of gratitude they owed to the Quakers, and then, too, they had their own grounds of animosity against the other elements in the colony. After the middle of the century it was only the vigorous support of the Germans, who held the balance of power, that enabled the Quakers to maintain their hold upon the political helm. ${ }^{3}$ But decades before that the Germans were coöperating with the Quakers and supporting them in their government. Palatine and Quaker labored together as builders of the commonwealth. ${ }^{4}$ And herein lies the significance of the first two

${ }^{2}$ Rufus M. Jones says: "Until the Revolution the Quakers and the Presbyterians constituted the rival political forces of the provinces. The Episcopalians tended towards the Friends and the Germans were also usually sympathetic." "The Quakers in the American Colonies," pp. 494 et passim.

8 "Parties were now [after 1763 ] formed on new lines. They had largely disappeared during the twenties and thirties, but at this time we find a marked difference, growing more emphatic with the years between the proprietary party and the 'country' party. The Quakers were now in considerable minority in the Province, but were practically all on one side. The Proprietors had left the Society and joined the Episcopal Church and that body rallied around them. So also did the Presbyterians, and all who believed in a vigorous, warlike policy. These stood together for proprietary rights and interests, and had as their stronghold the Governor and Council. The Friends and the Germans and their sympathizers maintained their ascendancy in the popularly elected Assembly, where they did practically as they pleased." Sharpless, "A Quaker Experiment in Government," pp. Io3 $f$.

4 "The Palatine and Quaker as Commonwealth Builders," by Frank I2 
decades of York County Germans for the early political history of Pennsylvania.

The York County Germans, like the great body of their countrymen east of the Susquehanna and between the Schuylkill and the Delaware, were generally on good terms with the provincial assembly. And these kindly feelings were mutual. They are reflected in the above narrative of the earliest German settlements in the county. The provincial authorities favored these Germans where they could and these Germans for the most part loyally supported the authority of the provincial government. The government allowed the Germans very easy terms of purchase for their lands west of the river. So long as the Indians did not complain the board of property winked at the settlement of squatters upon unpurchased lands. And finally in I733, in the matter of the Blunston licenses, the provincial authorities even strained a point in their traditional Indian policy in order to accomplish the settlement of the Germans in the Kreutz Creek Valley without delay. Afterwards when the Germans recovered from the illusion into which some of them had been misled concerning the jurisdiction over their lands and when they frankly acknowledged their error and asked to be restored to citizenship in Pennsylvania, the Council of Pennsylvania received them promptly and kindly, encouraged them in their allegiance and took measures to help them defend themselves. On this occasion the discussions in the provincial council and their letters to the governor of Maryland indicated very kindly feelings towards the Germans west of the river and a sincere sympathy for them in their

Ried Diffenderffer, is a very discerning discourse, showing the immense significance of colonial Pennsylvania in American history and the momentous influence which the combined forces of Germans and Quakers were able to exert upon that crucial colony. 
trying circumstances. And from that time forward none of these Germans ever again swerved in their loyalty to the Quaker government, though it cost them many serious annoyances.

It was the tenacity of the Germans in insisting upon their rights and in maintaining the Pennsylvania claims over those parts that prevented the Marylanders from taking possession of their lands and thus giving a large semblance of correctness to the Maryland claim of jurisdiction in the Kreutz Creek and Codorus Creek valleys. Whatever the Quaker officials may have thought about the intelligence and culture of these Germans they recognized them as a good element to serve the important purpose of resisting the encroachments of the Marylanders. This service they performed and it was recognized by the government. But for the good understanding between these Germans and the Quaker government the boundary history of Pennsylvania might be very different from what it is.

Moreover, the substantial support which the York County Germans in company with the great body of their countrymen throughout the colony gave to the Quaker government was the decisive factor in helping the Quakers to maintain their ascendancy in the legislative assembly. For the Quakers had their political opponents within their own province. At first these consisted chiefly of the adherents of the Church of England, a class that was not numerous enough to be troublesome. But after the third decade of the eighteenth century the Scotch-Irish began to pour into the province in increasing numbers and as a class they aligned with the political enemies of the Quakers. Then began the political contest against the power of the peaceful Quakers which dragged on until the Revolution when the Scotch-Irish finally triumphed. But meanwhile 
the Quakers had achieved remarkable results. Slowly, very slowly, through their continual disputes with the governors and proprietors, they had evolved for their province a body of constitutional liberty. Patiently, persistently, unconsciously they wrought, striving to maintain the honor of Christian civilization in the province's dealings with the Indians, and gradually working out the great constitutional principles which were the political pride of provincial Pennsylvania. This they accomplished in spite of the opposition of the Scotch-Irish and the Church of England people. And they accomplished it because they were regularly supported by the ballot of the Germans. The Germans had no political ambitions for themselves. As a class they were politically indifferent. ${ }^{5}$ They were satisfied with the government of the Friends, they had their own grounds for gratitude to them, they disliked the Scotch-Irish and they regularly voted with the established power. A great many of the Germans were religiously akin to the Quakers, and everywhere they came into conflict with the Scotch-Irish. The Scotch-Irish as a class were settling on the outer belt of civilization on lands contiguous to the Germans and this brought about many conflicts between the two nationalities. And it has been suggested that it was these conflicts that eventually evolved a political self-consciousness on the part of the Germans themselves. ${ }^{6}$

5 They were capable of being stirred by great principles, as is abundantly evidenced by their brilliant part in the French and Indian War and by their early rush to the cause of the Revolution, where they proved to be the most skilled soldiers in the Continental Army. And they soon developed great leaders among themselves and men of political influence, like Weiser and the Muhlenbergs. Nevertheless, the very earliest German settlers as a class had no ambitions to interfere in the affairs of others or to participate actively in public politics, and years elapsed before they developed a political self-consciousness.

6 This suggestion is made by Julius Goebel, who says: "Es scheint dass 
This is the perspective in which to view the relation of the York County Germans to the colonial history of Pennsylvania. For the documents concerning the early settlements in York County and the difficulties with the Marylanders reflect not a few instances of this partisan national spirit. When the German settlements in York County were taking their beginnings the Scotch-Irish had not yet arrived there and the chief opposition to the Quaker government and their faithful subjects west of the river came from Irish Catholics and from adherents of the Church of England. Thomas Cressap was an Irish Catholic from Maryland and so were his close associates at the mouth of Cabin Branch. ${ }^{7}$ When Cressap was captured and imprisoned in Philadelphia the troubles west of the river were continued and even intensified under the leadership of another Irishman, Charles Higginbotham. Shortly thereafter Samuel Blunston wrote to President Logan that there is now not so much to fear from the Marylanders as from "our own people," that band of "Irish ruffians with Higginbotham." The reference is to the aftermath of the unsuccessful Chester County Plot. That plot had been headed by three Irishmen, Charles Higginbotham, Henry Munday, and Edward Leet, and was participated in by others with Irish names. ${ }^{8} \quad$ But the great majority of the participants were English or Scotch and the entire plot was

sich die Deutschen am politischen Leben der neuen Heimat vor der Mitte des 18. Jahrhunderts wenig beteiligten. Wie liesse sich auch von den Verfolgten und Gedrückten, die aus dem Vaterland kein politisches Empfinden mitbrachten, anderes erwarten? Erst langsam, wohl im Kampfe mit den Irländern und Schotten, die seit den zwanziger Jahren nach Pennsylvanien $\mathrm{zu}$ strömen beginnen hat sich ihr poltitisches Selbstbewusstsein entwickelt." "Das Deutschtum in den Vereinigten Staaten von NordAmerika," p. 32.

7 Vide, e. g., Archives, I: 516 .

8 Vide the list of those involved, Col. Rec., IV: ro2. 
carried by the Pennsylvania enemies of the Quaker government. It was a minister of the Church of England who conceived the plot and directed its execution. ${ }^{9}$ The governor and council of Maryland wrote to the King, February $18, \mathrm{I} 737$, relating how the Germans on the Kreutz Creek had renounced the authority of Maryland and adding this comment: "and in order to account for this their extraordinary proceeding they declared their unwillingness to contribute towards the support of the ministers of the Church of England by law established in this province." And about a month later Governor Ogle of Maryland wrote to the Pennsylvania authorities: "Suppose a number of your Inhabitants touched with a tender Regard for the Church of England and the support of its Ministers (and such a Case certainly is not impossible, however improbable it may be judged to be) should all of a sudden renounce your Government in the same formal manner that these People did ours for contrary Reasons, pray what would your Government do in such a Case?"10 These expressions serve to indicate the national and ecclesiastical element that entered into the conflict.

Moreover in the face of the Chester County Plot Samuel Blunston wrote to Thomas Penn, October 2I, I736, requesting that vigorous efforts be made to prevent "the Irish from Chester County" from helping to dispossess "the Dutch west of Sasquehannah" on the ground that "it might be difficult to get the Donegal people to go against their country men." The Donegal people and others east of the Susquehanna were expected to help de-

${ }^{9}$ Henry Munday wrote to Rev. Jacob Henderson, November 14, 1736, "You being the first that projected the settling the said Lands and Plantations." Col. Rec., IV : roz. Henderson was also one of the Commissioners for Maryland.

${ }^{10}$ Col. Rec., IV : I88. 
fend the Germans if necessary even as they had helped to capture Cressap and four of his associates. Now the posse of 25 persons who had effected the capture of Cressap and his associates was officially described as consisting "mostly of German Protestants \& other Europeans of the Communion of the Churches of England and Scotland, of late years arrived here."11 Hence it is clear that Blunston, himself a Friend, realized that he could not depend upon the aid of the Church of England people and the Presbyterians to support the authority of the Quaker government when that authority conflicted with the wish of other members of those faiths. No love was lost between the Germans west of the river and those of the English just east of the river who were not Quakers. In one of the forceful conflicts between these two parties in 1735 one of the Germans specially laments the fact that he "was knocked down by an Irishman."12

The contest with the Scotch-Irish in York County did not begin until after the period which we have studied but the coming feuds were foreshadowed. Very shortly after the Germans had made a beginning of their settlements in York County the Scotch-Irish had begun to settle in that part of the Cumberland Valley which drains into the Potomac. And they were making an unfavorable impression. Scotch-Irish immigration into Pennsylvania had begun about I7I5. James Logan had early complained to the proprietor against this class of immigrants, their crowding in where they are not wanted, and their cruel treatment of the Indians. "It looks as if Ireland is to send all her Inhabitants." But with I734 the ScotchIrish began to come in much larger numbers. In that year they first settled in the Cumberland Valley, and already

11 Col. Rec., IV : r2:8.

12 John Lochman in Proceedings of Council of Maryland for r735, p. 83. 
on August I 5 of that same year, Samuel Blunston, writing to Thomas Penn concerning the terms for warrants west of the river, expresses his opinion of these Scotch-Irish in these words:

How far these terms may be liked by the loose setlers on potomac I know not, for though they may be easy in themselves, yet to them who were always a sort of free-booters they may seem strict enough for tis generally at present settled by such people who in all probability wil never be able to comply with the terms prescribed, nor are many of them at present able to pay for their warrants or surveys; nevertheless I think considering the dispute between the provinces they ought to be encouraged \& I am of opinion it would be well they had warrants \& surveys though it remained a debt on the place for those who come after to pay, for tis very probable few now settled there will be the possessors at the end of seven years But for some consideration assigning their rights to more industrious \& able persons will stil remove further, such idle trash being generally the frontiers of an improving colony. However poor as they are since they are the present Inhabitants as I said before I think they should be encouraged to keep them in possession, but I only speak this of those Inhabitants towards Potowmac.

Blunston evidently wishes to draw a sharp distinction between the earliest settlers in the Cumberland Valley and his German neighbors just west of the Susquehanna.

Blunston's expectations that these earliest Scotch-Irish settlers among the headwaters of the Conococheague would not long remain there but would soon be succeeded by a different class of settlers, were abundantly fulfilled by the subsequent course of events. For when the Scotch-Irish began to settle in York County violent conflicts took place between them and the Germans. ${ }^{13}$ For the sake of the peace of the province, therefore, the proprietors in 1749

13 Vide, e. g., Rupp's "History of Lancaster and York Counties," pp. $581-585$. 
instructed their agents not to sell any more lands in York County to the Irish but to hold out strong inducements to people of that nationality to settle further north. This suggestion, however, seems to have had little effect in the way of diverting the stream of Scotch-Irish immigration from the immediate neighborhood of the Germans. But meanwhile the Germans themselves had begun to supplant the Scotch-Irish, so far as they were settled upon good soil, by buying out their lands and improvements. From York and Lancaster Counties and the counties farther east they crossed Adams County and the South Mountain into the Cumberland Valley and purchased the holdings of the Scotch-Irish there, while these removed north across the Susquehanna or west beyond the Blue Ridge. This process of supplanting the Scotch-Irish began as early as 1757 and by the time of the Revolution the limestone Cumberland Valley was occupied predominantly by Germans. ${ }^{14}$

The significance of the early York County Germans for contemporary history of Pennsylvania, therefore, grows out of their warm support of the Quaker regime, their stout opposition to the Maryland claims, and their contact and conflicts with the Scotch-Irish. And this last, as we have seen, is involved in their regular choice of limestone lands.

14 Egle's "History of Pennsylvania," p. 6I'5. Rupp has also noted this same process of Germans supplanting Scotch-Irish in Northampton County, Rush's "Account of the Manners of the German Inhabitants of Pennsylvania," Schmauk edition, p. 57, footnote 35. Also Rupp's “History of Lancaster and York Counties," p. 576, footnote.

Ascherwall in his "Observations on North America" in I767 says: "Scotch and Irish often sell to the Germans, of whom from 90 to $100, \infty 0$ live in Pennsylvania, and prefer to put all their earnings into land and improvements. The Scotch or Irish are satisfied with a fair profit, put the capital into another farm, leaving the Germans owners of the old farms." Ascherwall received his information from Franklin the year previous. Pennsylvania Magazine of History and Biography, Vol. 27, p. 5. 


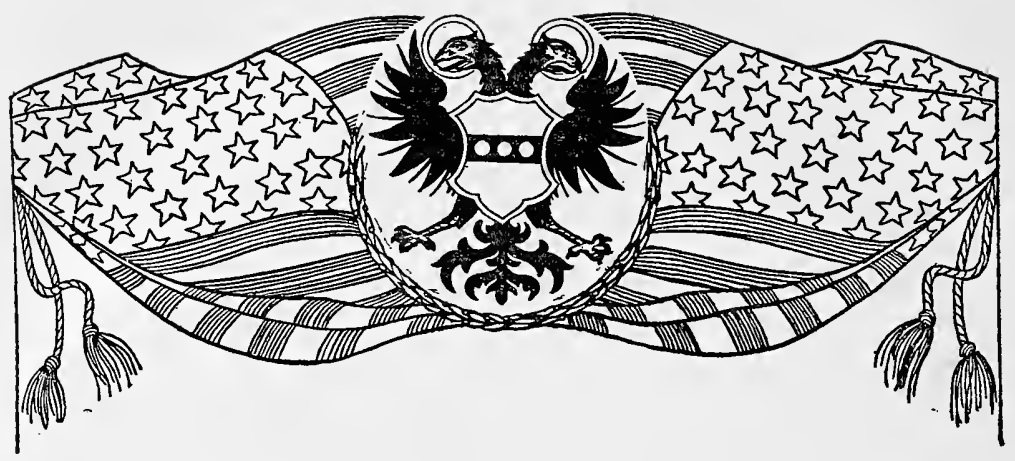

CHAPTER IX.

Their Place in General American History.

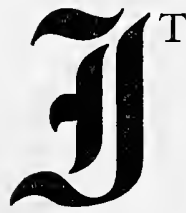

$T$ remains but to indicate with a few strokes the position of these early communities in the general course of American civilization. Of course in so far as colonial Pennsylvania was a formative factor in American history and in so far as these Germans helped to give direction to events in colonial Pennsylvania, their place in American history may be gathered from the preceding chapter. But they have also another significance for American history, a significance that comes not indirectly from the part they played in the history of their own province but directly from their own influence upon American life and civilization.

So far as numbers and possessions are concerned they constituted only a very small part of the American nation and their significance in themselves when weighed in the balances of the whole continent must necessarily be very small except in so far as they are indicative of a larger movement and prognostic of a greater future. In fact they constitute but a small portion even of the German 
element in the population of colonial America. But when viewed in the perspective of nearly two centuries they are seen to be the very van of a great movement that has made the American nation and moulded the American character and fixed American institutions. In the light of what has already been said concerning their distinguishing characteristics it must appear that their national significance is entirely disproportionate to their numbers and their holdings. Their significance for the history of American civilization and the evolution of American institutions lies partly in their location, partly in their occupation, and partly in their qualities of character.

In the first place, the Germans in York County before the middle of the eighteenth century were upon the very frontier of American civilization. Now the whole history of the American advance even down to our day is the history of the western frontier. The peculiarity of American institutions is the result of successive waves of westward expansion. The forces dominating American character today are the outgrowth of the gradual development from the simplicity of primitive industrial society to the complexity of modern manufacturing civilization. Over and over again this process has been repeated on each new frontier line as the population from decade to decade has marched with steady step across the American expanse. This continual rebirth of American life has given indelible stamp to our national character and our national institutions. The European has conquered the wilderness but during the process the wilderness has reacted upon the European and made him over into a new character with new ideas and new ideals. The frontier has been the meeting-point between civilization and savagery and thus it has constituted the crucible in which the different Euro- 
pean nationalities have been moulded into an entirely new product known as the American.

The westward advance of the frontier has taken place in well-defined stages marked by natural boundary lines. At the end of the seventeenth century the frontier was the fall line, the edge of the tide-water region of the Atlantic coast. By the middle of the eighteenth century it had advanced to the Alleghanies. During the Revolution the frontier crossed the Alleghanies and by the end of the century reached the Ohio. At the end of the first quarter of the nineteenth century it had advanced to the Mississippi. By the middle of the nineteenth cenutry it lay along the Missouri. Shortly thereafter it leaped across the Rockies and by the centennial year it had reached the Pacific and had begun to swerve northward towards Canada and Alaska. Thus has the retreating frontier marked the stages in the growth of the nation.

At each of these boundary lines the process of American transformation has been very similar. First came the Indian trader's frontier. The Indian had followed the buffalo trail. Now the trader, the pathfinder of civilization, follows the Indian trail and begins the disintegration of savagery. He is soon followed either by the miner or the rancher, and the trail is widened into a road. Then comes the pioneer farmer to exploit the soil, render it "barren," and then move on to virgin lands. He is followed by the steady farmer who devotes himself to intensive culture and permanent settlement, and he converts the road into a turnpike. This denser farm settlement is followed by city and factory with all the complexity of manufacturing organization. The turnpike has now been transformed into a railroad and the process of Americanization is complete. Each of these stages has wrought political 
and economic transformations and has contributed something towards the finished American product. ${ }^{1}$

In this process of American history it is not difficult to determine the place of the York County Germans as they appeared during the period which has come under our view. They fall within that stage when the Atlantic coast was yet the only settled area and when the frontier was slowly advancing up the courses of the Atlantic rivers towards their headwaters and towards the Alleghanies. But in this transition from the coast to the mountains the York County settlements constitute an important step. The first to settle west of the Susquehanna in this region, and among the first of all the settlements west of this natural dividing-line, the early German communities of York County stand like an auspicious prognosticator pointing westward beyond the South Mountain and the Blue Ridge and inviting to the conquest of the Alleghanies and the promising lands beyond. Like an entering wedge into the Indian country this tongue of German settlements pushed forward indenting the wilderness, broadening the national horizon, and inspiring to almost limitless acquisition of empire.

When the Germans settled in York County the Indian trader's frontier had passed. The Indian had withdrawn into the interior and with him had gone the trader. The mining explorer had also had his day in York County. It was time for the farmer's frontier and this was the posi-

1 For this view of American history we are indebted to Professor F. J. Turner, of Harvard. A brief statement of Professor Turner's philosophy of American history together with valuable suggestions as to the concrete influence of the frontier upon certain phases of American character and American institutions, is found in his article "The Significance of the Frontier in American History" in the Annual Report of the American Historical Association for the year 1893, pp. 197-247. 
tion occupied by the Germans. Throughout colonial times Pennsylvania was the basis of distribution of frontier emigration and the settlement of York County is signifcant as one of the earliest steps in this Pennsylvania expansion southward and westward. The observer who takes his stand among the Delaware and Shawnese Indians on the west bank of the Susquehanna at the opening of the eighteenth century will see the successive stages of the American frontier passing before his view in exactly the same order in which they afterwards pass the many natural boundaries in their westward course to the Pacific. With the beginning of the fourth decade of that century Indian resistance will have ceased, the farmer with intensive methods of culture will have arrived, the next to the last stage in the process of complete Americanization will have been reached, and there will remain but one more step to make this region one of the most populous and thriving communities in the New World. The place of the first decades of York County Germans in general American history may be seen from the fact that they constituted the farmer stage of the American frontier during a critical period in the frontier advance. The settling of these Germans was like the formation of an artery in the embryo of the nation that was yet to be.

The movement of the Germans across the Susquehanna was a decided step in advance. Others had come as far as that river but had halted and hesitated to cross. Before the first authorized settlement had been made in York County the Quaker settlements had been slowly pushing westward along the northern part of Lancaster County. In I727 a number of Quakers, among them Samuel Blunston, John Wright, and Robert Barber, had settled at Hempfield, on the east bank of the Susquehanna. But 
here the westward migration of the Friends halted for more than a decade. The cause of this delay in their progress was the boundary dispute with Maryland and the Cressap War which resulted from that dispute. Not until I $73^{8}$ did the Quaker movement continue across the river and begin the belt of Quaker settlements which extends across the northern part of York County. ${ }^{2}$ Meanwhile the German wave of westward immigration had arrived. This tide suffered no serious check either from the river or from the Cressap War. These hardy and resolute Germans quickly crossed the river, plunged boldly into the forest, and bore the brunt of the border difficulties with the Maryland intruders. Not until this critical and difficult stage in the history of that frontier had been passed and quiet had been restored did the other nationalities sweep into the county after them. To the Germans, therefore, was reserved the special mission of occupying in a peculiar sense the very forefront of the farmer stage of the frontier in this part of the American advance beyond the Susquehanna.

But even within the farmer stage of the American advance there are usually two or three distinct periods in each case. Two or three classes of farmers follow one another across the frontier. First is the pioneer farmer whose wants are few but who seeks quick results. He searches out the bare spots or those most easily cleared and begins to exploit the virgin soil. He has no ambition to become the owner of his holding for he expects soon to take up his march again. With the simplest implements of agriculture, a rude log cabin, and a rough shed for a stable, he occupies his range until he has completely drained the soil

${ }^{2}$ Albert Cook Myers, "The Immigration of the Irish Quakers into Pennsylvania, I682-17'50," pp. I612 and 180. 


\section{German Element in York County, $\mathrm{Pa}$.}

of its strength or until he is crowded by neighbors. Then he disposes of his "improvements" and moves on to new soil to carry out the same process again.

The second class of farmer is the settler who stakes out his claim, takes measures to secure a survey, and negotiates for the purchase of that which he occupies. He welcomes neighbors into his community, builds a church and schoolhouse, and practices the arts of civilized life. He builds a substantial house and often a more substantial barn. His house is of hewn logs, with windows of glass and a chimney of brick or stone. His barn is made to shelter a large number of domestic animals and to store the products of careful cultivation. He rotates his crops and fertilizes his lands so as not to exhaust the soil. He adds to his fields from year to year and settles down to plain and frugal but contented living. This is the class of farmer that usually continues to occupy his improvements and thus forms the nucleus of permanent settlement.

Sometimes this second class is followed by a third class, the capitalist. This man of enterprise buys out some of the substantial properties of the second class. Industrial enterprises are begun on a larger scale. Villages are laid out and soon grow into towns. Large edifices arise; higher education begins; the finer arts of civilization are practiced; and above all manufacturing industries begin, factories loom into view, and the community has brought forth a city. This class marks the transition to the final stage of the American frontier.

Now the York County Germans before the middle of the century belong almost exclusively to the second class of the farmer stage. The third class did not make its appearance among them until somewhat later. And the first class mentioned above never did have a place in the 
German belt of York County. The typical pioneer farmer with his superficial methods of cultivation was well represented, as we have seen, among the earliest inhabitants of the southeastern part of the county. But the German settlers on the limestone belt belonged entirely to the second class. They came intending that their settlements should be permanent and they proceeded accordingly in their methods of clearing and improving. ${ }^{3}$ And it is a remarkable fact that these early settlers usually continued to occupy their original possessions until their death. They added to their belongings but in very few cases did they migrate from their settlements. The good soil had attracted them to these valleys and their own skillful methods of cultivation kept them there. As their growing families demanded more lands they spread out and occupied more and more of the Cambrian belt but usually remained in the same general neighborhood.

Despite the difficulties that confronted them in their new homes these German farmers in the first half of the eighteenth century flourished rapidly. Many of them when they died were possessed of property whose value is a

3 These intensive methods were the result of inheritance and of experience and hence it was a rare thing to find a German exhibiting the characteristics of the earliest class of pioneer farmers. Where the Germans have gradually occupied large farming areas they have done so not by migration but by expansion. An appreciative description of the characteristics of the German farmer in colonial Pennsylvania is that from the pen of their contemporary, Dr. Rush, in his "Account," Schmauk edition, pp. 54-73.

The preference of the German farmer for forest land, his intensive methods of culture, and the consequences of this combination in the subsequent prosperity of the German farmer in the northwest, are described by Emil Rothe in his article on "Die Entwicklung des Deutschtums im Nordwesten," in Jahrgang II, 2. Heft (April 1870), p. 55 et passim, of "Der Deutsche Pioneer." 
splendid monument of their industry and economy. ${ }^{4}$ In their position as a flourishing farming community they were not without significance not only for the early history of Pennsylvania but even for the general course of American history. It has been asserted that these "farms of the

4 This rapid prosperity of the original settlers is abundantly proved by a study of their wills and by the inventories of their property at their death. Thus the inventory of Christian Croll (completed on August 22, I7581) indicates a remarkable growth to wealth during the 25 years of his settlement in York County. Among his possessions are the following:

"Houses and Lots in Yorktown

2 Houses and lots in High Street .............. $£_{490}$

House and lot at the North and Water Street ......... $£_{50}$

One do at the east end of Race Street ............ £45

One do adjoining Jos Adlums House ........... £8o

Improvement bought of Geo Albright .................

Improvement bought of Jacob Hoague ............ $£_{120}$

Patent Lands on west side Conewago .............. £ 140

Part of the improvement in partnership with Mr. Stevenson. $£_{70}$ "

The list of "chattels" covers I9 pages. Of these there are articles to the value of $£ 35$ I ro $\mathrm{s}$. 8 p. in "the Shop," and others to the value of $£ 4$ I s. 6 p. in "the Bar." The "book debts" cover 9 pages and amount to about $£ 750$. Two pages of these are called "debts due for smith work." The inventory indicates that the total of his possessions at his death amounted to $£_{3,476} 8 \mathrm{~s}$. $9 \mathrm{p}$.

But Christian Croll had become a blacksmith in York and his extraordinary prosperity may have been due partly to that fact. More typical perhaps is the inventory of Jacob Welshover ( 17158$)$ and for that reason this inventory is reproduced in full in Appendix $C$.

The inventory of the property of John Jacob Kuntz (September I7, 1754) estimates his plantation alone at $£ 320$. The inventory of Frederick Lether (made July 8 , $x_{746}$, that is, before York County was established) estimates his "Blandation or Improvement" at $I_{50}$ and his total possessions at $£ 2326 \mathrm{~s}$. 6 p. For Micheal Spengler whose inventory was made on March 20,1748 , the "Big Plantation" is placed at $£_{350}$ and his "Chattels" at $£ 292$. The inventory of Balser Shamberger (made April 28, 175I) estimates his "improvement and winter grain" at $£ 200$. John Kuhns (inventory dated May 26, 1753 ) had personal estate alone valued at $£ 37 \times 5 \mathrm{~s} .8 \mathrm{p}$. These inventories are thoroughly typical and indicate a remarkable degree of early prosperity on the part of these first settlers. 
Germans became the wheat granary of the world."5 From this point of view their significnce might be traced in a great many directions. Suffice it to say here that not until we have formed a correct estimate of the service of the American farmer to the American nation will we be able to determine with precision the place of the early York County Germans in general American history. As a part of that great body of prosperous farmers who have always constituted the very bone and sinew of our national existence, the York County Germans of the first half of the eighteenth century have more than ordinary significance for the national history of their times.

And finally, the Germans of York County before the middle of the eighteenth century occupy a distinct place in general American history because they fulfilled a special mission in the general movement of Germans in this country. That the great body of Germans in the United States has at all periods of our history had a decided cultural influence upon American institutions is now freely recognized on all sides. ${ }^{6}$ The relation of the early German settlements of York County to the other German settlements of that time has already been set forth in detail. ${ }^{7}$ Their significance lies in the fact that they occupied advance ground. They had moved out on the frontier farther

5 By Professor Turner as quoted in Faust, I: $x_{3} 8$ and II: 36 .

6 For a general evaluation of the German element in this country see Faust, "The German Element in the United States," Vol. II; Rudolf Cronau, "Drei Jahrhunderte Deutschen Lebens in Amerika"; and Bosse, "Das Deutsche Element in den Vereinigten Staaten."

7 Supra, Chapter VI.

The position of the Pennsylvania Germans in general among the other nationalities in colonial Pennsylvania, and the circumstances that led to the prominent part of the Germans in the Revolution from England, are suggested in Pfister, "Die Amerikanische Revolution r7715-r783," pp. 5I-97 and $x 28-x 70$. 
than any other of the numerous German settlements in Pennsylvania. This was both a result and a cause of certain distinguishing elements of character which they manifested in their lives and conduct. These Germans made a new frontier but the frontier made them over into a new nationality. The peculiarity of their position coupled with their previous experience and their special characteristics gave them freer rein for self-government than any other German community had and it made them more susceptible to the reflex influence of the New World. Separated from the great body of their countrymen in America and free from all ties that might bind them to the Fatherland, they soon began the process of Americanization. The unconscious charm of the locality quickly made its impress upon their plastic German souls. The length, the breadth, the giant height and the rich depth of the new continent left an indelible stamp upon their characters and quietly transformed them into a new people. From the soil of their new homes and from the incidents and circumstances of their new life arose the inexorable forces that compelled them to stand forth a new type of world's citizen. The period which we have studied marks little more than the beginning of this important process of transformation. But already at the time of the Revolution the process is fairly complete. At the report of the first shot at Lexington they showed themselves the best Americans of us all and when General Washington in camp at Valley Forge felt that he was in the enemy's country the center of the German belt in York County was the home of the national capital. The first two decades of York County Germans constituted one of the first chapters in the Americanization of the great and influential German element in this country. 


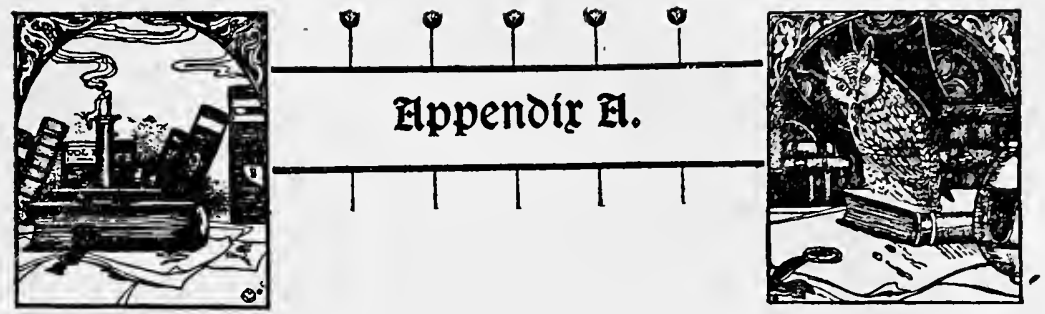

Letter of Samuel Blunston to the Proprietors, APRIL 9, 1735.

May it please the proprietors:

By John Hendricks I received a letter which informs me of his complaint of the unfair \& dishonest usage he has met with from John Wright \& me in relation to the land opposite to us. As I well know we are clear of any such charge I shal according to your desire give a full relation to the whole affair \& coppys of letters sufficient I hope to satisfy you that no imputation of unfair practice can justly be charged on either of us.

In the later part of the year I 726 John Hendricks being over the river Turkey Hunting with some of his relations through a stupid carelessness or fatal mistake shot a young man his first cousen \& killed him. This accident \& some ill management of his affairs put him upon selling the place where he lived \& to gain a new settlement in the spring of the year 1727 he applyed to J: Logan for leave to settle over the river oposite to us teling him the Indians were desirous he $\&$ his brother James should settle there. J: Logan haveing heard the Marylanders designed to survey that land upon this application of John \& also of one Jos: Chaphem wrote me the following letter: Friend Saml Blunston: I am informed that some persons from Maryland have proposed to survey \& take up that tract of land where the Shawanna Indians were lately settled on the west side of Sasquehannah opposite to Hempfield to prevent which \& for their own accomodation John Hendricks \& Hendrick Hendricks sons of Jacobus Hendricks are desirious to seat themselves there as also Joseph Chapham would willingly make some settlement. Therefore if thou please to run lines about the 
best part of that tract taking in about 1000 or 1500 As or more for William Penn grandson to the late proprietor who devised 10,000 acres of land in this province to his grandson by will. And return the draught thereof to me, I shall satisfie thee for thy trouble therein. And if the sd Brothers \& Jos Chapham can obtain the consent of the Shawannah the chief of those Indians we should be willing they should make settlements on those parts of the tract as may be convenient for themselves $\&$ at the same time the least injurious to the remainder of it $\&$ be pleased to inform me what thou does herein who am with respect thy loving friend J Logan Philadelphia May ıo, I727.

This is the letter \& the only letter or pretense on which J Hendricks founds his claim \& by this you will see the land was not apparently laid out for him, \& by this both he and his brother James (who is there called Hendrick) \& Jos Chapham were but to settle on part of it the least Injurious \&c But the letter speaks for itself \& I proceed. In the month of July following pursuant to sd order I went over \& marked four corners including the greatest part of the tract after surveyed \& no more was done at that time the weeds being so high we could not chain it nor carry an instrument to any purpose.

About this time or a little before the afsd Henry Hendricks \& one Thomas Linvil went \& settled at Codorus a Creek about 12 miles west of sd River which settlements disturbing the Indians they threatened to burn their houses and obliged $\mathrm{Em}$ to quit their settlements \& return back to this side. The Indians opposing the peoples settling hindered John Hendricks from removing thither that year as he had intended for as some of the chief of the Indians told me John had no liberty from them as he had falsely reported to J : Logan Now as all the 3 persons before mentioned were to have but part of that tract \& Jos Chapham wholy declined settling there \& went to Carolina John Wright \& I thought we might without any injustice ask leave to secure a part of it for ourselves, some further attempts being made to settle it. Accordingly when John Wright went to town the August following \& spoke to J : 
Logan in behalf of himself upon which \& some other affairs $\mathrm{J} L$ wrote the following part of a letter:

Phila ro August 1727

My frd S. B : J Wright spent the last evening with me \& informs me that the people having got a notion that those Indians of the 5 nations who were here lately had assigned all their claim to the lands about Sasquehannah were now crowding upon those lands beyond the River in order to settle them though this part of the Indians is surely a mistake. As he desires a part of that rooo acres formerly mentioned to be secured for one of his boys. I am very willing he should be favoured in any thing that is practicable of that kind, and that the land should be kept for him from all others, if it may be done \& in order to it would have him take some proper methods to secure it. But people must be no means be allowed to take up lands \& make settlements on that further side, otherwise then as it may answer some other necessary end. Nor would we by any means have the Indians to quit their settlements there or abandon those parts of Sasquehannah. I mean principally the other side of it.

In the fall of the year the Marylanders continuing their incroachments Jno Wright \& I in a letter joyntly to J Logan gave him an account thereof $\&$ made request that we might have something from them to show a right to part of the afsd land (which then all lay vacant) that we might be the better able to prevent others who had designs to come there. John Hendricks also being with him about that time to make a second request for leave to go to that tract J Logan thereupon wrote to us joyntly a letter upon the subject of the Maryland incroachments, \& upon the present affair, the part thereto relating as follows:

Phila 30/8/1727/ Jno Wright \& Sam'l Blunston: Loving frds: In answer to yours of the 28 th instant I must observe \&c here he gives a pretty large account of a former agreement between the two provinces about the boundaries \& then says . . I I wish we could fal on any possible measures to prevent their settlements, if you can 
think of any it would be very acceptible, if at the desire of the Commisioners which you may take as expressed in this letter you would be pleased to put $\mathrm{Em}$ in practice. I prompted John Hendricks to write of his affair to you though I can say nothing further than what I told himself viz: that since he has not yet settled which I thought he had done long since, \& the Indians insist on our former agreement not to suffer any such, it woud be extremely Irregular in us at this time to agree to it. As to the land opposite agt you I believe we shal all be very willing that you should take any measures to secure it without giving offence to the natives we can make no grant at present but any thing else in our power we should readily consent to.

From the concessions or promises in these letters mentioned rose our expectations that in a proper time we might be able to make some of that land our own upon the credit hereof with much care \& pains prevented it from being settled by others which we till this time have done.

In the year I 728 the Indians grew more cool as they perceived if they hindered our people the Marylanders would have it. John Hendricks without any further licence removed over and took his choice of the whole tract settling where he now lives Now though by the first letter of J L it plainly appears that (I) the whole tract was never intended to be the sole property of $\mathbf{J}$ Hendricks. So it also appears by that $\&$ the other letters already quoted which will also be corroborated by what follows that the tract though ordered to be surveyed for the use of W. Penn was not strictly so intended, that survey then made $\&$ his name used as most proper to secure it from the Marylanders they not being then willing to have any survey made to private persons lest others might claim the like power.

In the year I 729 the Marylanders made a fresh attempt upon us $\&$ that produced the following paragraph in a letter from J Logan to me bearing date the 29th of Novemb I 729 where he thus concludes: "I am told just now here that they are surveying all the Land over Sasquehannah from Maryland and sel it again to our people. Pray discourage it to the utmost $\&$ do thou also survey to perplex Em. And in another letter dated the $4^{\text {th }}$ of December 
following are these words: I wish thou would exert thyself \& make surveys in any name whatsoever \&c From all which the intention of these surveys I think plainly appear; according to the foregoing orders \& some others I wrote him a letter dated the 30 th of November Afsd which among other things contains what follows: I have laid out the Land for the Donegal Congregation according to thy order \& $I$ think to the satisfaction of all parties \& have given them a draught thereof. I have also this week perfected a Survey of that piece of Land over the River on which J. Hendricks is settled of which I shall return thee a draught by the first opportunity. The whole contains about 1200 Acres, Six Hundred whereof regularly divided being the uper side \& best part of the tract and on which J. Hendricks has settled we have left to him But he is so far from being satisfied with it that Except he could have it so as to spoil the whole tract he will I suppose apply for a Maryland right for redress. All the land about Parnels is surveyed \& settled by Marylanders \& many people out of this province are for removing over the river so that I doubt not but another year will settle most of the habitable land for they flock over daily in search. The remainder of that by Hendricks would have been settled before now had they not been prevented. John Wright \& I desiring it may be kept vacant at present that when opportunity presents we may obtain grants for it. . .

About the year I 73I the before mentioned James Hendricks went \& settled on the back part of the tract on which John lived It always being understood to be their equal right \& early in the Spring I732 John \& James and their father Jacobus went down together on that side with their Guns intending to shoot some turkeys at the place where John had before shot his cousin, and in the way the old man's Gun went of by accident \& killed James Dead on the Spot his Death occasioned his widdow to leave the place which she after sold to Joshua Minshal who now lives on it. Nothing more was done till after the first of you arrived when J Hendricks Jos Minshal John Wright \& myself altogether applied to the Honourable Proprietary for the Grants for our several parts of the sd tracts as itt had been last surveyed and divided \& John Hendricks then made no 
demand or claim to any more then his share with Jos Minshal in the six hundred acres. How the other wild notion since got into his head I know not.

Thus having traced it down from the first beginning to this present it is time so conclude. And I hope enough is said to convince you that we never had any the least intention to act an unjust part therein towards J Hendricks or any other person. And as you desired an account from me I hope you will be so kind as to let me know your sentiments of our Behavior therein. And if any Scruple yet remains with you that the licence or grant which I rec'd is on a bad foundation I am ready to resign it. Though the pains I have taken to secure it $\&$ my endeavours to prevent the mischiefs which have hapened on that side has been to me a source of continued care and trouble. I do not mention this to make merit of any thing $I$ have done nor do I expect or desire any reward but what proceeds from a consciousness of having done my duty. The land I am ready at all times to pay for if it be thought I am honestly in possession of it, otherway I made no claim.

For the rest of the letter I need only say I have not heard of the taxgathers being up. If they come with an evil intent I shall us my endeavours to circumvent Em.

As to the Behavior of John Wrights Sons or any other persons on this side towards Hendricks he is so far from having any Ground for complaint that they and many others have long borne \& yet do bear his intolerable abuses $\&$ insults purely upon your account which else would never be suffered.

As to Cressops Complaint agt the Magistrates the Charge is too General to receive any other answer than that I know nothing of it. I am with great regard your assured ffrd

Sa Blunston

Apr. 9th in the evening 1735

The Messenger staid a little longer than expected which gave me time to finish this. 


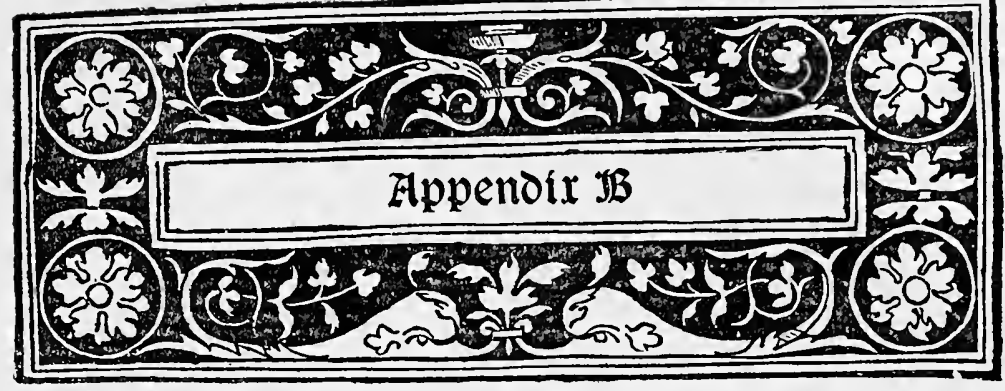

Names of Those Who Signed the Letter of the Germans to the Governor of Maryland, August i I, I736 (CAlvert Papers,
No. 7 I 7 ).

These names are all included in the list of those for whose arrest a warrant was issued on October 21, I736, "for contriving signing and publishing a seditious paper and writing against his Lordship and this government." The names are here given as copied by the clerk in Maryland and that accounts for the peculiar spelling.

Jacob Grable

Jacob Seglaer

Conrade Lowe

Christian Lowe

Jacob Seglaer, jr.

Michael Aringall

Philip Seglaer

Dennis Myer

Hans Stanner

Tobias Spright

Tobias Hendricks

Leonard Immel

Balchar Sangar

Methusalem Griffith
Gorrick Cobell

Kelyon Smith

Nicholas Peery

Micheal Tanner

Micheal Wallack

Micheal Evat

Micheal Miller

Jasper Carvel

George Swope

George Philier

Nicholas Butchier

Andrew Phlaviere

Henry Stantz

Henry Lephart 
204 German Element in York County, Pa.

Peter Gardiner

Jacob Lonus

Nicholas Conn

Bartholemew Shambarrier

Henry Young

Caspar Varglass

Bryonex Tander

Christian Crowle

Conrade Stricklaer

Henry Bowen

Francis Worley, jr.

Martin Sluys

Jacob Hoopinder
Michael Raisher

Tobias Fray

Martin Fray

Henry Smith

Jacob Welchhutter

Henry Henricks

Charles Jones

Adam Byer

Godfrey Fray

Nicholas Hatchley

Micheal Waltz

- Martin Wyngall

Eurick Myer

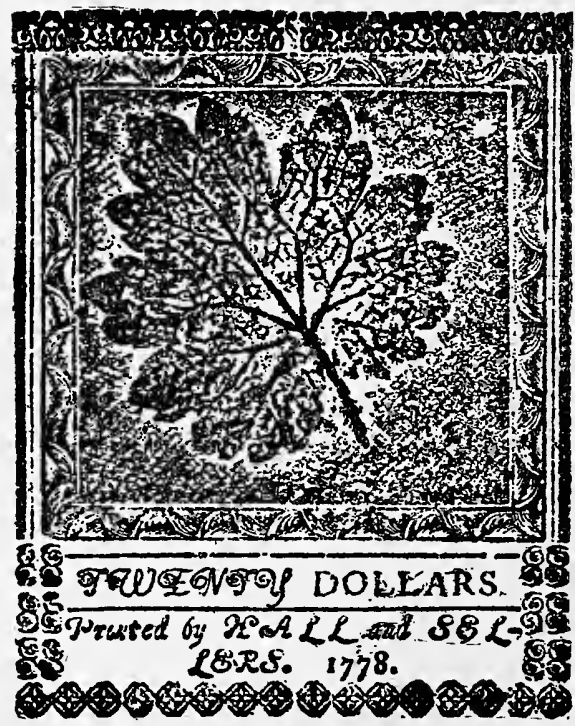




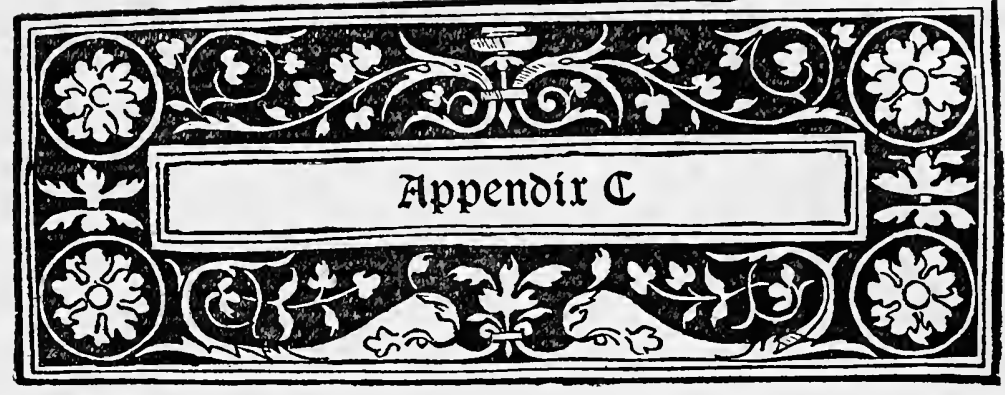

Inventory of the Estate of Jacob Welshover.

Jacob Welshover's will was made on November I 5, I 757, and witnessed by Heinrich Schmidt and Heinrich Libhart. It was probated on June 29, I758. The appraisement was made on August 24, 1758, by Heinrich Schmidt and another German. The inventory totals $£ 495$ I 8 s. o p. The items are as follows:

7 Cows $\ldots \ldots \ldots \ldots \ldots \ldots \ldots \ldots \ldots \ldots \ldots \ldots$

the other young horn Cattle $\ldots \ldots \ldots \ldots \ldots \ldots$ I2- 0

5 sheep $\ldots \ldots \ldots \ldots \ldots \ldots \ldots \ldots \ldots \ldots \ldots \ldots, \quad \mathrm{I}-\mathrm{IO}-\mathrm{O}$

2 Wagon horses $\ldots \ldots \ldots \ldots \ldots \ldots \ldots \ldots \ldots \ldots, 20,0,0$

I Meare $\ldots \ldots \ldots \ldots \ldots \ldots \ldots \ldots \ldots \ldots, 6 \ldots \ldots, 0,0$

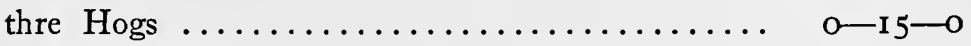

Io Hives of Bees $\ldots \ldots \ldots \ldots \ldots \ldots \ldots \ldots \ldots \ldots, \quad 3-10-0$

I high Wagon $\ldots \ldots \ldots \ldots \ldots \ldots \ldots \ldots \ldots \ldots$. I3 -0

6 ould wagon wheals $\ldots \ldots \ldots \ldots \ldots \ldots \ldots \ldots, 5-0,0$

2 Blows ....................... I-10

I Iron Harrow $\ldots \ldots \ldots \ldots \ldots \ldots \ldots \ldots \ldots, \quad I-5 \rightarrow 0$

5 braks ......................... 0

4 collers Iron trasis brich bands bridle ......... 4-10

Doung plows forks Shoffels pitch forks ......... O-I $7-0$

the wind mill \& Sives Riddels ............. I-IO-O

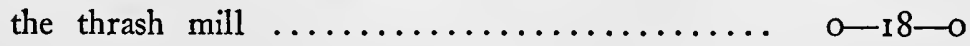


the cottin box

$0-14-0$

2 large Roaps and a blow line

$0-4-0$

Wheat and Rey of 16 Acre of ground

$16-0-0$

2 acre of Hemp in the field

$3-10-0$

the Still \& the Iron \& worm blongin to it

$18-0-0$

9 Tobs in the Still house

$\mathrm{I}-\mathrm{I} 2-\mathrm{O}$

a box where the keep the Chopt Rey in

$0-5 \rightarrow 0$

washing Tobs \& other tobs \& rails \& Halbushel ..

$\mathrm{I}-\mathrm{O}-\mathrm{O}$

Clean Hemp

$6-0-0$

Earthen pots dishes \& plats

$0-6 \longrightarrow 0$

the hogsheds \& other casks in the Seller ........

$3-10-0$

Rey Liquer four Barrels ..................

$9-\mathrm{IO}-\mathrm{O}$

Talow about 15 pound $\ldots \ldots \ldots \ldots \ldots \ldots \ldots \ldots$

$0-6-0$

butter Cands or boxis \& pokeds ................

meal and wedges from broad ax $\ldots \ldots \ldots \ldots \ldots$

$0-5-0$

Draw Knife Oagers Chisels ............... I $\mathbf{I}-5-0$

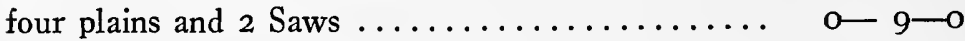

2 Cross Cut Saw \& the Brand mark .......... I-IO-O

the wagon or hand screw $\ldots \ldots \ldots \ldots \ldots \ldots \ldots, \quad \mathbf{I}-\mathbf{I} 5-0$

2 old bells \& a pair of Stilliels .............. o o- $9-0$

2 Hatchets ....................... I- $2-0$

Brass Cettels \& other Brass ............... 5- $5-0$

2 Tables \& 4 Chairs ................... I-10 -0

the Iron of an ould Chist a Cobbert \& Doadrough . I- I- $0-0$

Dresser in the kitchen ................. I-IO -0

a Cloathbed $\ldots \ldots \ldots \ldots \ldots \ldots \ldots \ldots \ldots \ldots, \quad 2-10$

A Clock ........................... 4-0

A water Cand \& baskeds .................. $0-8-0$

Iron pots $\&$ pans $\&$ other things $\ldots \ldots \ldots \ldots \ldots, \quad 2-0,0$

Tea pot a pair of Ballons ................ $0-12-0$

All the Beuter plats dishis spoons \&c ......... 2-15-0

Tinn quarts fonnel \& other things $\ldots . \ldots \ldots \ldots ., 0-6-0$

Bowls tea Cups \&c ...................... o- $3-0$

Bibles \& other books .................. 2-0

Sacks \& Cloth for a wagon Cloth ........... 3- $1-0$

Blankets vinegar Cask a gun Spining wheals ..... 2- 2-0 
Inventory of Estate of Jacob Welshover. $\quad 207$

2 Beds \& bed Sted Slats ................ 5- $5-0$

a Flower Chist ...................... I5- 0

Coat \& Chacket britches \& Shirts ............ 2- 2-5-0

Table Cloth Sheets \& other lining ........... I- $\mathbf{I}-0$

Linsy woolsy $\ldots \ldots \ldots \ldots \ldots \ldots \ldots \ldots \ldots . \quad \mathbf{I}-4-0$

2 Chains $\ldots \ldots \ldots \ldots \ldots \ldots \ldots \ldots \ldots \ldots \ldots, \quad 0-15-0$

Bees wax ....................... 0 - 10

an ould Spining wheal \& sum yearn $\ldots \ldots \ldots \ldots \ldots, \quad 0-12-0$

30 bushel of Wheat $\ldots \ldots \ldots \ldots \ldots \ldots \ldots \ldots .3,3-15-0$

20 bushel of Rey ................... I-I3-0

40 bushel of oats ................... 2-10-0

5 bushel of flax Seed .................. $0-12-0$

a mans Sattle \& a womens Saddle ............ I- I- $5-0$

Tenn Pounds in money .................. 10- 0

One Stove $\ldots \ldots \ldots \ldots \ldots \ldots \ldots \ldots \ldots \ldots, 3-15-0$

for the improvement $\ldots \ldots \ldots \ldots \ldots \ldots \ldots \ldots .250-0-0$

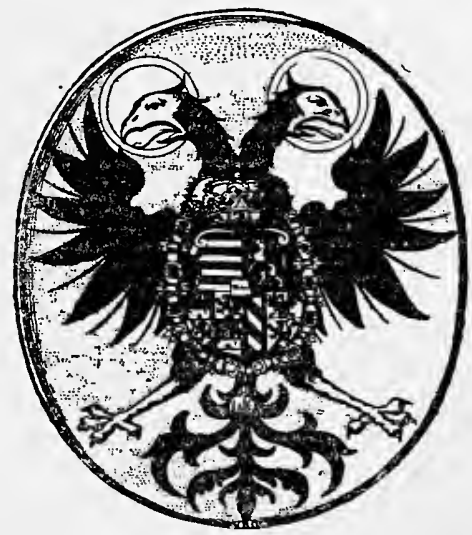




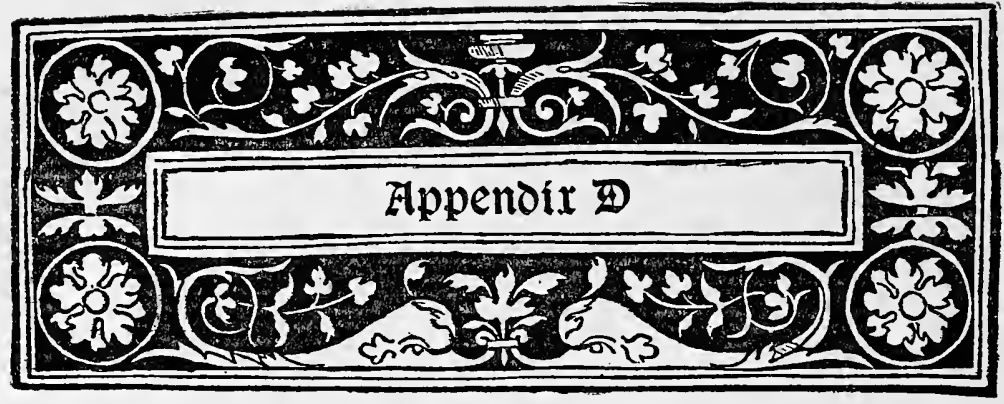

\section{BIBLIOGRAPHY.}

\section{Primary Sources.}

The Pennsylvania Archives.-Of direct value for our subject among these are chiefly the early volumes of the First Series, Volumes I-III. The designations in the text, Archives I, Archives II, etc., always refer to the corresponding volume of the First Series. These were selected and arranged from original documents in the Office of the Secretary of the Commonwealth by Samuel Hazard in I85I and 1852 . Some of the others that come into consideration for our subject are Volume VII of the Second Series, containing "Papers relating to Provincial Affairs in Pennsylvania, I682-1750," edited by John B. Linn and W. H. Egle, I878; and Volumes I and II of the Fourth Series, containing the Papers of the Governors, edited by George E. Reed, I900.

The Colonial Records; or Minutes of the Provincial Council of Pennsylvania from the Organization to the Termination of the Proprietary Government.-Materials bearing directly on our subject are found principally in Volumes II-V containing the acts of the Council from I 700 to I754. These records were published by the State in $185 \mathrm{I}$ and $\mathrm{r} 852$. The designation in the text "Col. Rec." always refers to the Colonial Records of Pennsylvania.

The Proceedings of the Provincial Council of Maryland, published as the Maryland Archives under the auspices of the Maryland Historical Society.-Of chief interest for our subject are the proceedings for the years I735-I 737 . 
York County Court Records.-Deeds, wills, and inventories, beginning with the year I 749 .

Lancaster County Court Records.-Deeds, wills, and inventories, beginning with the year 1729 .

The Calvert Papers.-These are deposited in the Historical Society of Maryland, Baltimore. Most of these remain unpublished but some were published in the Maryland Archives, and the No. 2 which contains materials bearing on our subject was published separately as one of the Fund Publications.

The Original Church Record of Christ Church, York, Pa.

The original Church Record of St. Matthew's Church, Hanover, Pa.

Documents in the Department of Internal Affairs (Land Office) at Harrisburg. Letters, Ledgers, Journals, and Day-Books, Depositions in Internal Affairs, Personal Papers, Warrants and Patents, and files of old Grants and Drafts.

Documents in the Division of Public Records, State Library, Harrisburg. Especially the Provincial Papers $(1681-1776)$ and the lists of names of German immigrants from 1727 to 1775 .

"Miscellaneous Manuscripts of York and Cumberland Counties, I738-1806," in the Historical Society of Pennsylvania, Philadelphia. One letter from this collection is reproduced in full in Appendix $A$.

"The Penn Papers"-Historical Society of Pennsylvania.

"The Logan Papers"-Historical Society of Pennsylvania.

The Collections of the York County Historical Society gathered in the Court House at York. This includes a host of valuable manuscripts, historical objects, maps, and drawings, which have here been used directly or indirectly.

A Scrap-Book of Mr. M. O. Smith of Hanover, Pennsylvania, containing newspaper articles constituting his "History of York County," I 869-1 875.

\section{Secondary Sources.}

Following is a list of the books that have been used in the preparation of this study and cited in its presentation: 
Bernheim, Gotthardt Dellmann. History of the German settlements and of the Lutheran Church in North and South Carolina, from the earliest period of the colonization of Dutch, German, and Swiss settlers to the close of the first half of the present century. Philadelphia: The Lutheran book store, 1872. xvi, 557 pp. $12^{\circ}$.

Bittinger, Lucy Forney. The Forney Family of Hanover, Pennsylvania, 1690-1893. Pittsburgh: 1893. iv, 59 pp. $4^{\circ}$.

Bosse, George von. Das deutsche Element in den Vereinigten Staaten. Stuttgart, 1908.

Carter, W. C. and A. J. Glossbrenner. History of York County from its erection to the present time. York, $1834.16^{\circ}$.

Cobb, Sanford H. The Story of the Palatines. An episode in colonial history. New York and London: G. P. Putnam's Sons, 1897. ix, 319 pp. Maps. $8^{\circ}$.

Cronau, Rudolf. Drei Jahrhunderte Deutschen Lebens in Amerika. Eine Geschichte der Deutschen in den Vereinigten Staaten: mit 2 Io Illustrationen. Berlin, D. Reimer (Ernst Vohsen), 1909. xiii, 640 pp. $4^{\circ}$.

Day, Sherman. Historical Collections of the State of Pennsylvania, containing a copious selection of the most interesting facts, traditions, biographical sketches, anecdotes, etc. Philadelphia; George W. Gorton, I843. 708 pp. $8^{\circ}$.

Dallas, George Mifflin. Reports of the proceedings of the Circuit Court of the district of Pennsylvania. Volume VI.

Der Deutsche Pioneer. Eine Monatsschrift für Erinnerungen aus dem Deutschen Pioneer-Leben in den Vereinigten Staaten. Cincinnati: 1870. Jahrgang II. 2. Heft. Article by Emil Rothe, "Die Entwicklung des Deutschtums im Nordwesten," pp. 50-54 and $84-89$.

Diffenderffer, Frank Ried. The Palatine and Quaker as Commonwealth Builders. An Address delivered before the Pennsylvania Historical Society at Philadelphia, March I4, I898. Lancaster: 1899. $30 \mathrm{pp} .8^{\circ}$.

Ebeling, Christoph Daniel. Erdbeschreibung und Geschichte von 
Amerika. Die Vereinigten Staaten von Nordamerika. Vierter Band. Hamburg: 1797. 914 pp. $12^{\circ}$.

Egle, William Henry. (I) Notes and Queries, Historical and Genealogical,-chiefly relating to Interior Pennsylvania. In two volumes. Harrisburg: 1895 and I896. Volume I. 1895. Volume II. I896. ix, 47I pp. (2) An Illustrated History of the Commonwealth of Pennsylvania, civil, political and military, from its earliest settlement to the present time, including historical descriptions of each county in the State. Harrisburg: 1876 . xii, I 186 pp. $8^{\circ}$.

Falkenstein, George N. History of the German Baptist Brethren Church. Illustrated. A reprint from the proceedings of the Pennsylvania German Society for I900. Lancaster: I90I. $\mathrm{x}, \mathrm{I} 54$ pp. $8^{\circ}$.

Faust, Albert Bernhardt. The German Element in the United States, with special reference to its political, moral, social, and educational influence. Illustrations. Maps. Boston and New York: 1909. Volume I, xxvi, 59 I pp. Volume II, xvi, 605 pp. $8^{\circ}$.

Fisher, Sydney George. (I) The Making of Pennsylvania. (2) Pennsylvania, Colony and Commonwealth. Philadelphia: 1897 . xiii, 442 pp. $8^{\circ}$.

Fiske, John. The Dutch and Quaker Colonies in America. In two volumes. Boston and New York: I9or. Volume II, xvi, 294 pp. $8^{\circ}$.

Freytag, Gustav. Bilder aus der Deutschen Vergangenheit. 5 . Aufl. Leipzig: 1867. Volume III.

Gibson, John. History of York County, Pennsylvania, from the earliest period to the present time, divided into general, special, township and borough histories, with a biographical department appended. Illustrated. Chicago: 1886. ix, 772 and 207 pp. $4^{\circ}$.

Glossbrenner, A. J. and W. C. Carter. History of York County from its erection to the present time. York: $1834.16^{\circ}$.

Goebel, Julius. Das Deutschtum in den Vereinigten Staaten von 
Nord-Amerika. 16. Heft. Der Kampf um das Deutschtum. München: $1904.90 \mathrm{pp} .8^{\circ}$.

Goetz, W. Deutsche Erde und Deutsches Volk. Chapter two in the collection "Deutschland als Weltmacht." Berlin: vii, 848 pp. Chapter two, pp. 4-27. $8^{\circ}$.

Hallesche Nachrichten. Nachrichten von den Vereinigten Deutschen Evangelische-Lutherischen Gemeinen in Nord-Amerika, absonderlich in Pennsylvanien. Mit einer Vorrede von D. Johann Ludwig Schulze, Halle, in Verlegung des Waisenhauses, I 787. Neu herausgegeben von W. J. Mann, B. M. Schmucker, unter Mitwirkung von W. Germann, Erster Band. Allentown, Pa: Verlag von Brobst, Diehl \& Co., I886. x, 723 pp. $8^{\circ}$.

Häusser, Ludwig. Geschichte der Rheinischen Pfalz. Heidelberg, 1856 .

Heiderich, Franz. Länderkunde von Europa. Sammlung Göschen. Leipzig: 1897. I82 pp. $12^{\circ}$.

Höen, Moritz Wilhelm. Das Verlangte nicht erlangte Canaan bey den Lustgräbern. Franckfurt und Leipzig: (Andreä), I 7 II. (16), I27 pp. 16 .

Jones, Rufus M. The Quakers in the American Colonies; assisted by Isaac Sharpless and Amelia M. Gummere. London: I9I I. xxxii, 603 pp. $8^{\circ}$.

Kalm, Peter. Reise durch Nordamerika. Translated by J. R. Forster. Warrington; I770-I77I. In 3 volumes. Illustrated. Volume I.

Kapp, Friedrich. Geschichte der Deutschen im Staate New York bis zum Aufange des neunzehnten Jahrhunderts. New York: I867. vii, 4 IO pp. $8^{\circ}$.

Kuhns, Oscar. The German and Swiss Settlements of Colonial Pennsylvania: a study of the so-called Pennsylvania Dutch. New York: I9or. (2), v, 268 pp. $12^{\circ}$.

Levi, Mrs. Kate Asaphine Everest. How Wisconsin came by its large German Element. Madison, Wisconsin: I892. 38 pp. $8^{\circ}$. Folded map. Reprinted from State Historical Society of Wisconsin Collections, volume I2. 
Lutheran Quarterly. A quarterly theological magazine. Published at Gettysburg, Pennsylvania. Article in Volume XIII (1883), pp. 509-515, "The Relation of the Lutheran Church in the United States to the Lime-Stone Districts," Sylvanus Stall. Article in Volume XVIII (I888), pp. 473-529, "The Lutheran Church in York, Pa.," Beale M. Schmucker.

Lutheran Church Review. A quarterly theological magazine. Published at Philadelphia. Article in Volume XV (1896), pp. 134ff., "The Lutheran Church and Pennsylvania in the 17th Century," T. E. Schmauk. Articles in Volume XXII (1903), pp. I4ff., 313ff., $565 \mathrm{ff}$. "The Lutheran Clergy of London and How They Aided the German Migration during the 18th Century." J. F. Sachse.

Memoirs of the Historical Society of Pennsylvania. Volume I. Article by J. Dunlap, pp. 163-204, "The Controversy between William Penn and Lord Baltimore."

Mittelberger. Gottlieb Mittelbergers Reise nach Pennsylvanien im Jahr I750 und Rückreise nach Teutschland im Jahr 1754 . Frankfurth und Leipzig: I 756. (8), I20 pp. $16^{\circ}$.

Myers, Albert Cook. The Immigration of the Irish Quakers into Pennsylvania, I682-I750. With their early history in Ireland. Illustrations. Maps. Swarthmore, Pennsylvania: 1902. xxii, 477 pp. $8^{\circ}$.

Pastorius, Franz Daniel. Umständige geographische Beschreibung der zu allerletzt erfundenen Provintz Pennsylvaniae, in denen End-Gräntzen Americae in der West-Welt gelegen. Etc. Frankfurt und Leipzig: Zufinden bey Andreas Otto, I700. (12), 140 pp. $16^{\circ}$.

Penn, William. (I) Some Account of the Province of Pennsylvania in America. London: 168I. Io pp. (2) Eine Nachricht wegen der Landschaft Pennsylvania in America. Translation of the above. Amsterdam: 1681. (3) Information and direction to such persons as are inclined to America, More especially those related to the province of Pennsylvania. London: 1682. 4 pp. (4) Brief Account of the Province of Pennsyl- 
vania. (5) Kurtz Nachricht von der Americanischen Landschaft Pennsylvania. Amsterdam: I682.

Pennsylvania Annual Report of the Secretary of Interior Affairs, for the year 1905. Part I. Harrisburg: 1906. I99 pp. $8^{\circ}$. Pennsylvania German Society. Proceedings and addresses. Volumes I-2I. Published annually by the Society. I89I-I9I2. Illustrations. Plates. Portraits. Facsimiles. Maps. $4^{\circ}$.

"The Pennsylvania German." A magazine. Published at Lebanon, Pa. I900-1913. Volumes I-VI, quarterly; volumes VII-XIV, monthly. Discontinued 19I3. Volume II, No. 4, pp. I84-I88: article "The Pennsylvania German Farmer." George Mays.

Pennsylvania Magazine of History and Biography. Volumes 27 and 33.

Pennypacker, Samuel Whitaker. Pennsylvania in American History. Philadelphia: I9I0. 494 pp. $8^{\circ}$.

Pfister, Albert. Die Amerikanische Revolution, I775-I 783, Entwicklungsgeschichte der Grundlagen zum Freistaat wie zum Weltreich unter Hervorhebung des deutschen Anteils. Zwei Bände. Mit einer Karte. Stuttgart und Berlin: 1904. Erster Band: $\mathrm{x}, 400 \mathrm{pp} .8^{\circ}$.

Prowell, George. History of York County, Pennsylvania. Illustrated. Chicago: 1907. Volume I, I I 8 pp. $4^{\circ}$. Ratzel, Fredrich. Deutschland. Einführung in die Heimatkunde. Leipzig: I898. viii, 332 pp. Illustrated. Maps. $12^{\circ}$.

Reiley, John T. Conewago: A Collection of Catholic Local History. Gathered from the fields of Catholic Missionary Labor within our reach. Martinsburg, West Virginia: I885. 220 pp. $8^{\circ}$. Illustrated.

Riehl, W. H. Die Pfälzer. Ein rheinisches Volksbild. Dritte Auflage. Stuttgart und Berlin: 1907. xiv, 315 pp. $12^{\circ}$. Roosevelt, Theodore. The Winning of the West. Volume I. Sagamore edition. New York and London: I889. 288 pp. $16^{\circ}$. 
Rupp, I. Daniel. (I) History of York and Lancaster Counties, from the earliest settlements made within them; in the former from 1709 ; in the latter from 1719 , to the present time; to which is prefixed a brief sketch of the early history of Pennsylvania from A.D. $168 \mathrm{I}$ to the year 17 10. Lancaster: I845. 750 pp. $8^{\circ}$. (2) A Collection of Upwards of Thirty Thousand Names of German, Swiss, Dutch, French and other Immigrants in Pennsylvania from 1727 to 1776 , etc. 2nd edition. Philadelphia: 1880. viii, pp. 495. German and English. $8^{\circ}$.

Sachse, Julius Friedrich. (I) The German Pietists of Provincial Pennsylvania, 1694-1 708. Philadelphia: 1895. xviii, 504 pp. Illustrations. Plates. $4^{\circ}$. (2) The German Sectarians of Pennsylvania, I708-1742; a critical and legendary history of the Ephrata Cloister and the Dunkers. Philadelphia: 1899 . $\mathrm{xx}, 506$ pp. Illustrations. Plates. $4^{\circ}$. (3) The German Sectarians of Pennsylvania, I742-1800; volume II of the above. Philadelphia: 1900: xvi, 535 pp. $4^{\circ}$. (4) Falkner's Curieuse Nachricht von Pennsylvania. The book that stimulated the great German Emigration to Pennsylvania in the early years of the XVIII Century. Philadelphia: 1905. x, 256 pp. Illustrations. Plates. $4^{\circ}$. (5) The Fatherland: 1450-1700, showing the part it bore in the discovery, exploration, and development of the western continent, with special reference to the Commonwealth of Pennsylvania. Lancaster: 1897. xi, 234 pp. $4^{\circ}$. (6) The Trappe Records. Volume V. Proceedings of the Pennsylvania German Society. 1896. pp. 159-283.

Schmauk, Theodore E. (I) An Account of the Manners of the German Inhabitants of Pennsylvania by Benjamin Rush, M.D. Volume XIX, Proceedings of the Pennsylvania German Society. 1910. 126 pp. $4^{\circ}$. (2) A History of the Lutheran Church in Pennsylvania (1638-1820). Volume I. Reprinted from Proceedings of Pennsylvania German Society. Philadelphia. 1903. xxvi, $588 \mathrm{pp} .4^{\circ}$.

Seidensticker, Oswald. Geschichte der Deutschen Gesellschaft von Pennsylvanien. Von der Zeit der Gründung, I764 bis zum 
Jahre I876. Festgabe zum Jubeljahre der Republik. Philadelphia: 1876.336 pp. $8^{\circ}$.

Seydlitz, E. von. Handbuch der Geographie. "Der Grosse Seydlitz." 25. Bearbeitung, besorgt von Professor Dr. E. Oehlmann mit 400 Figuren, Karten, Profilen und Landschaftsbildern in Schwarz und Photographiedruck, 4 farbigen Karten und 30 farbigen Tafeln. Breslau: 1908. xvi, 848 pp. $8^{\circ}$.

Sharpless, Isaac. A Quaker Experiment in Government. Philadelphia: 1898. $280 \mathrm{pp} .8^{\circ}$.

Shriver, Samuel S. The Shriver Family, I684-1888. Baltimore I888. I 68 pp. $4^{\circ}$.

Small, Samuel, Jr. Genealogical Records of George Small, Philip Albright, Johann Daniel Dünckel, William Geddes Latimer, Thomas Bartow, John Reid, Daniel Benezet, Jean Crommelin, Joel Richardson. Philadelphia: 1905. 363 pp. $4^{\circ}$.

Spangler, Edward W. The Spengler Families with Local Historical Sketches, I150-1896, the Annals of the Families of Caspar, Henry, Baltzer, and George Spengler. York: 1896. xii, 605 pp. $4^{\circ}$.

Stapleton, A. Memorials of the Hugenots in America with special reference to their emigration to Pennsylvania. Carlisle: I90I. ix, I64 pp. Illustrations. $8^{\circ}$.

Star and Sentinel. A Weekly Paper published at Gettysburg, Pennsylvania. The issues of March, 1876 .

Swank, James M. Progressive Pennsylvania. A Record of the remarkable industrial development of the Keystone State. Philadelphia: 1908 . vii, 360 pp. $8^{\circ}$.

Turner, Frederick Jackson. The Significance of the Frontier in American History. An Essay in the Annual Report for the American Historical Association for the Year 1893. Washington: 1894. Pp. 199-227.

Virginia Magazine of History and Biography. Richmond. Volume XI (1903-4), No. 2, pp. II3-I3I ; No. 3, pp. 225-242; No. 4, pp. 370-393; Volume XII (1904-5), No. I, pp. 55-82; No. 2, pp. I34-I53; No. 3, pp. 27I-284: Moravian Diaries 
of Travel through Virginia. Edited by W. J. Hinke and C. E. Kemper.

Wallace, W. A. Pennsylvania's Formative Influence upon Federal Institutions, 1682-1787. A lecture before the Historical Society of Pennsylvania, 1882 .

Wayland, John Walter. The German Element of the Shenandoah Valley of Virginia. Charlottesville, Virginia: 1907. xi, 272 pp. $8^{\circ}$.

Wheaton, Henry. Reports of Decisions of the Supreme Court of the United States, I816-1827. Volume IX.

Winsor, Justin. Narrative and Critical History of America, edited by Justin Winsor. Illustrations. Maps. Boston and New York: Volume III, 1884. xi, 578 pp. $4^{\circ}$. Chapter XII. Pp. 469-516, The Founding of Pennsylvania, Frederick D. Stone.

Yeates, Jasper. Reports of Cases Adjudged in the Supreme Court of Pennsylvania. Volume I. Philadelphia: 1817 . viii, 627 pp. $8^{\circ}$.

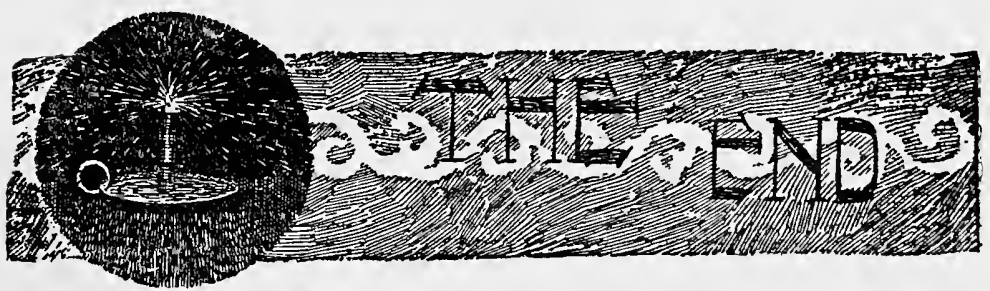





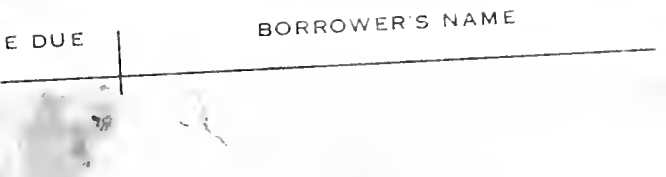


